\title{
Validating Mechanistic Sorption Model Parameters and Processes for Reactive Transport in Alluvium
}

\author{
M. Zavarin, S.K. Roberts, T.P. Rose, and \\ D.L. Phinney
}

May 2, 2002

U.S. Department of Energy

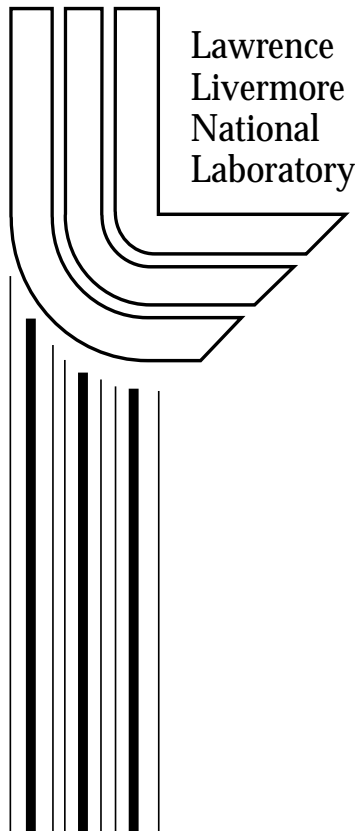




\section{DISCLAIMER}

This document was prepared as an account of work sponsored by an agency of the United States Government. Neither the United States Government nor the University of California nor any of their employees, makes any warranty, express or implied, or assumes any legal liability or responsibility for the accuracy, completeness, or usefulness of any information, apparatus, product, or process disclosed, or represents that its use would not infringe privately owned rights. Reference herein to any specific commercial product, process, or service by trade name, trademark, manufacturer, or otherwise, does not necessarily constitute or imply its endorsement, recommendation, or favoring by the United States Government or the University of California. The views and opinions of authors expressed herein do not necessarily state or reflect those of the United States Government or the University of California, and shall not be used for advertising or product endorsement purposes.

This work was performed under the auspices of the U. S. Department of Energy by the University of California, Lawrence Livermore National Laboratory under Contract No. W-7405-Eng-48.

This report has been reproduced directly from the best available copy.

Available electronically at http://www.doc.gov/bridge

Available for a processing fee to U.S. Department of Energy

And its contractors in paper from

U.S. Department of Energy

Office of Scientific and Technical Information

P.O. Box 62

Oak Ridge, TN 37831-0062

Telephone: (865) 576-8401

Facsimile: (865) 576-5728

E-mail: reports@adonis.osti.gov

Available for the sale to the public from

U.S. Department of Commerce

National Technical Information Service

5285 Port Royal Road

Springfield, VA 22161

Telephone: (800) 553-6847

Facsimile: (703) 605-6900

E-mail: orders@ntis.fedworld.gov

Online ordering: http://www.ntis.gov/ordering.htm

OR

Lawrence Livermore National Laboratory

Technical Information Department's Digital Library

http://www.llnl.gov/tid/Library.html 
UCRL-ID-149728

Validating Mechanistic Sorption Model Parameters and Processes for Reactive Transport in Alluvium

Mavrik Zavarin, Sarah K. Roberts, Timothy P. Rose, and Douglas L. Phinney

Lawrence Livermore National Laboratory

Livermore, California

Prepared for the Underground Test Area Project

U. S. Department of Energy

National Nuclear Security Administration

Nevada Operations Office

Final Report

May 2002 


\section{TABLE OF CONTENTS}

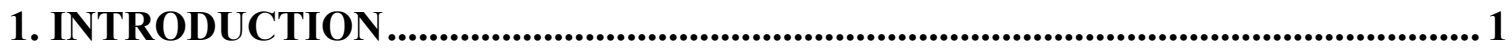

2. EXPERIMENTAL METHODS AND MODELING APPROACH......................... 2

2.1 MinERALOGIC CHARACTERIZATION OF U-1 A AND UE-5N ALLUVIUM...................... 3

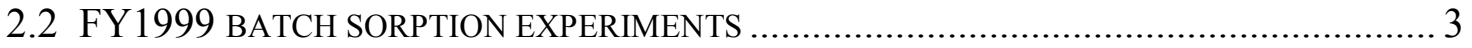

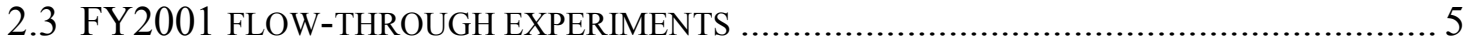

2.4 SECONDARY ION MASS SPECTROMETRY (SIMS) ANALYSIS OF FLOW-THROUGH

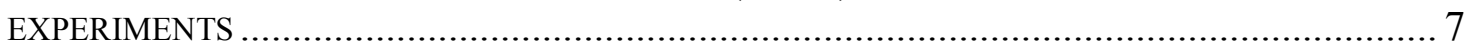

2.5 MODELING BATCH AND FLOW-THROUGH EXPERIMENTS ….................................... 9

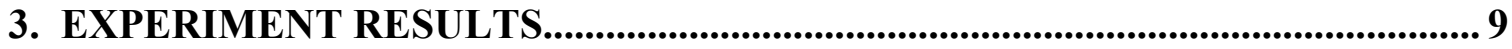

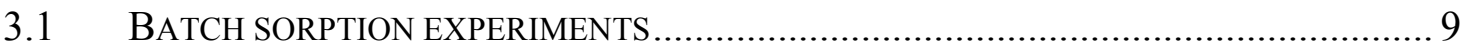

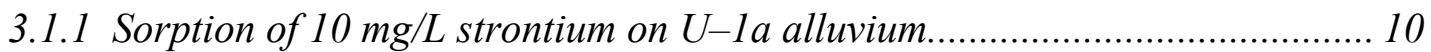

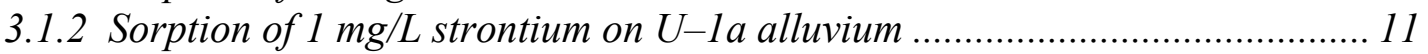

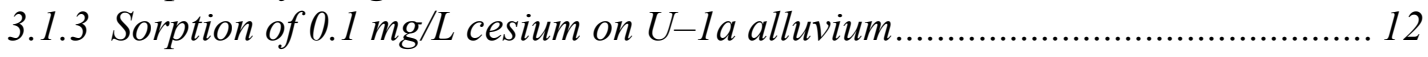

3.1.4 Sorption of $0.1 \mathrm{mg} / \mathrm{L}$ europium on $U-1$ a alluvium....................................... 13

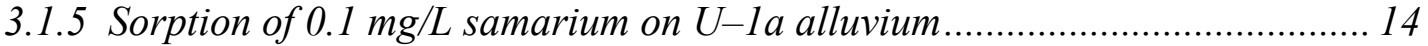

3.1.6 Summary of batch sorption experiments ................................................... 15

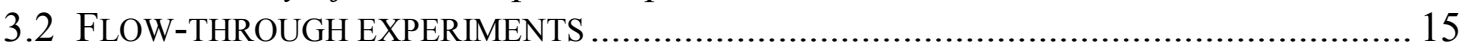

3.2.1 Experiment \#1: Iodide, cesium, strontium, samarium, and uranium transport

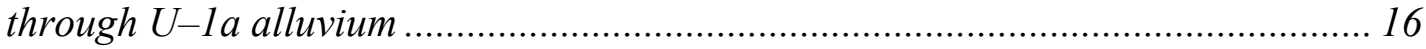

3.2.2 Experiment \#2: Iodide, cesium, strontium, samarium, and neptunium transport through $U-1$ a alluvium ................................................................. 19

3.2.3 Experiment \#3: Iodide, cesium, strontium, samarium, and uranium transport

through UE-5n alluvium ................................................................................ 20

3.2.4 Experiment \#4: Iodide, cesium, strontium, samarium, and neptunium

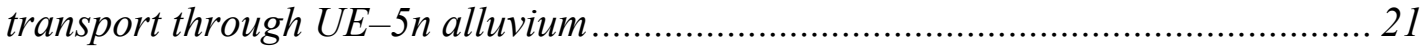

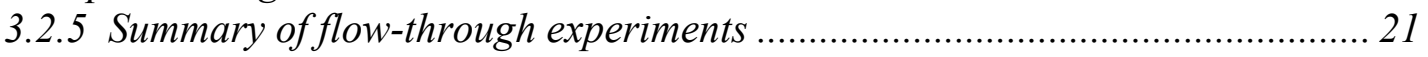

4. SUMMARY AND CONCLUSIONS........................................................ 22

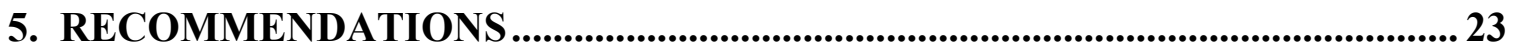

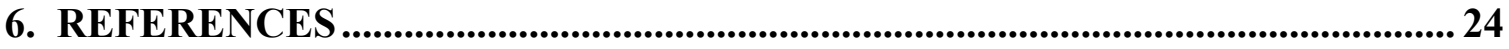

7. ACKNOWLEDGEMENTS.........................................................................................26

APPENDIX A. COLUMN BREAKTHROUGH DATA................................................. 48

APPENDIX B. QUANTITATIVE X-RAY DIFFRACTION DATA............................5 57

APPENDIX C. CHARACTERIZATION DATA FOR U-1A ALLUVIUM ............. 59

APPENDIX D. BATCH SORPTION DATA.....................................................................60 
APPENDIX E. SURFACE COMPLEXATION, ION EXCHANGE, AND AQUEOUS SPECIATION CONSTANTS AND MINERAL CHARACTERISTICS

USED IN MECHANISTIC SORPTION MODEL...................................................65

APPENDIX F. SECONDARY ION MASS SPECTROMETRY DATA..................... 71 


\section{LIST OF FIGURES}

Figure 1. PHOtOGRAPH OF COLUMN FLOW-THROUGH EXPERIMENT SYSTEM. .................. 31

FIGURE 2. PHOTOGRAPH OF SIMS SAMPLE MOUNTS PREPARED FROM EPOXY IMPREGNATED

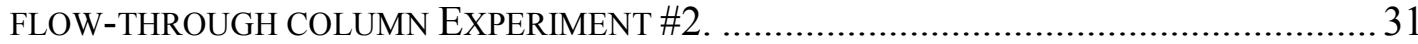

FIGURE 3. MEASURED AND PREDICTED CONCENTRATIONS OF STRONTIUM IN THE $10 \mathrm{MG} / \mathrm{L}$ STRONTIUM U-1A ALLUVIUM SORPTION BLANKS. AQUEOUS + SORBED STRONTIUM IN THE NON-SPIKED BLANKS WAS DETERMINED BY PREDICTING SORBED STRONTIUM FROM THE MEASURED NON-SPIKED AQUEOUS CONCENTRATIONS. INITIAL SR REFERS

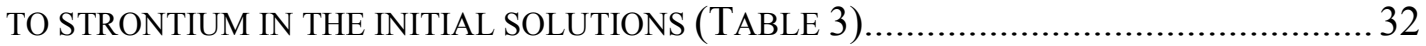

FiguRE 4. MEASURED AND PREDICTED CONCENTRATIONS OF STRONTIUM IN THE 10 MG/L STRONTIUM U-1A ALLUVIUM SORPTION SAMPLES. INITIAL SPIKED STRONTIUM DETERMINED FROM NON-SPIKED STRONTIUM IN BLANKS + SPIKE STRONTIUM. PREDICTED AQUEOUS STRONTIUM CALCULATED USING 0.85 MEQ/G (RED) AND 0.425 MEQ/G (GREEN) SMECTITE CATION EXCHANGE CAPACITIES. .

FigurE 5. MAJOR CATION CONCENTRATIONS IN THE 10 MG/L STRONTIUM U-1A ALLUVIUM SORPTION SAMPLES.

FIGURE 6. MEASURED AND PREDICTED CONCENTRATIONS OF STRONTIUM IN THE $1 \mathrm{MG} / \mathrm{L}$ STRONTIUM U-1A ALLUVIUM SORPTION BLANKS. AQUEOUS + SORBED STRONTIUM IN THE NON-SPIKED BLANKS WAS DETERMINED BY PREDICTING SORBED STRONTIUM FROM THE MEASURED NON-SPIKED AQUEOUS CONCENTRATIONS. INITIAL SR REFERS TO STRONTIUM IN THE INITIAL SOLUTIONS (TABLE 3).....

FIGURE 7. MEASURED AND PREDICTED CONCENTRATIONS OF STRONTIUM IN THE $1 \mathrm{MG} / \mathrm{L}$ STRONTIUM U-1A ALLUVIUM SORPTION SAMPLES. INITIAL SPIKED STRONTIUM DETERMINED FROM NON-APIKED STRONTIUM IN BLANKS + SPIKE STRONTIUM. PREDiCTED AQUEOUS STRONTIUM CALCULATED USING 0.85 MEQ/G (RED) AND 0.425 MEQ/G (GREEN) SMECTITE CATION EXCHANGE CAPACITIES.

FIGURE 8. MEASURED AND PREDICTED CONCENTRATIONS OF CESIUM IN THE $0.1 \mathrm{MG} / \mathrm{L}$ CESIUM U-1 A ALLUVIUM SORPTION SAMPLES. CESIUM-SMECTITE LOG K INCREASED TO 1.6. CESIUM-ILlite SITE I LOG K INCREASED By 1 TO 6.7. DiVAlENT CATIONILLITE SITE I LOG K INCREASED TO -0.75 FROM -2.05 .

Figure 9. PREDICTED DistribUtion OF CESIUM ON ION EXCHANGING MINERALS IN 0.1 MG/L CESIUM U-1A ALLUVIUM SORPTION SAMPLES. CLIN = CLINOPTILOLITE; ILL1 = ILLITE SITE I; ILL2 = ILLITE SITE II; ILL3 = ILLITE SITE III ; SMEC = SMECTITE ........... 35

FiguRE 10. MEASURED AND PREDICTED CONCENTRATIONS OF EUROPIUM IN THE $0.1 \mathrm{MG} / \mathrm{L}$ EUROPIUM U-1A ALLUVIUM SORPTION SAMPLES. PREDICTED AQUEOUS EUROPIUM CALCULATED ASSUMING EQUILIBRIUM WITH CALCITE (GREEN DOTS) OR ASSUMING EQUILIBRIUM WITH ATMOSPHERIC $\mathrm{CO}_{2}(\mathrm{G})$ (RED DOTS).

FIGURE 11. PREDICTED DISTRIBUTION OF EUROPIUM ON RADIONUCLIDE SORBING MINERALS IN THE $0.1 \mathrm{MG} / \mathrm{L}$ EUROPIUM U-1 A ALLUVIUM SORPTION SAMPLES. $>\mathrm{SIOEU}^{2+},>$ SIOEUO, AND $>$ ALOEU ARE SMECTITE SURFACE SITES, >EUCO3-CALC

ARE CALCITE SURFACE SITES. 36

FIGURE 12. MEASURED AND PREDICTED CONCENTRATIONS OF SAMARIUM IN THE $0.1 \mathrm{MG} / \mathrm{L}$ SAMARIUM U-1 A ALLUVIUM SORPTION SAMPLES. PREDICTED AQUEOUS SAMARIUM 
CALCULATED ASSUMING SOLUTION EQUILIBRIUM WITH CALCITE (GREEN), ASSUMING SOLUTION EQUILIBRIUM WITH ATMOSPHERIC $\mathrm{CO}_{2}(\mathrm{G})$ (RED), ASSUMING SOLUTION EQUILIBRIUM WITH ATMOSPHERIC $\mathrm{CO}_{2}(\mathrm{G})$ AND ADJUSTING SAMARIUM-CALCITE LOG K TO BE THE SAME AS FOR EUROPIUM (ORANGE), AND ASSUMING SOLUTION EQUILIBRIUM WITH ATMOSPHERIC $\mathrm{CO}_{2}(\mathrm{G})$ AND ADJUSTING CALCITE REACTIVE SURFACE AREA FROM 2.2 TO $0.5 \mathrm{M}^{2} / \mathrm{G}$ (WHITE). 36

FigurE 13. BREAKTHROUGH DATA FOR EXPERIMENT \#1 (U-1 A ALLUVIUM). LiNES REPRESENT THE FIT TO DATA USING OUR MECHANISTIC MODEL AND REACTION CONSTANTS AND MINERAL REACTIVITIES DEFINED IN APPENDIX E. THIN LINES REPRESENT MODEL FITS USING ADJUSTED CONSTANTS DEFINED IN TABLE 9.

FIGURE 14. IODIDE AND URANIUM BREAKTHROUGH DATA FOR EXPERIMENT \#1 (U-1A ALLUVIUM), 0 TO 20 PORE VOLUME RANGE. LINES REPRESENT THE FIT TO DATA USING OUR MECHANISTIC MODEL AND REACTION CONSTANTS AND MINERAL REACTIVITIES DEFINED IN APPENDIX E.

FIGURE 15. IODIDE AND URANIUM BREAKTHROUGH DATA FOR EXPERIMENT \#1 (U-1A ALLUVIUM), 60 TO 80 PORE VOLUME RANGE. LINES REPRESENT THE FIT TO DATA USING OUR MECHANISTIC MODEL AND REACTION CONSTANTS AND MINERAL REACTIVITIES DEFINED IN APPENDIX E.

FIGURE 16. SPATIAL DISTRIBUTION AND STRONTIUM ASSOCIATIONS WITH MINERALS IN COLUMN EXPERIMENT \#1 (U-1A ALLUVIUM). LINES REPRESENT THE FIT TO DATA USING OUR MECHANISTIC MODEL AND REACTION CONSTANTS AND MINERAL REACTIVITIES DEFINED IN APPENDIX E. SPATIAL DISTRIBUTION AT 65 PORE VOLUMES IS SHOWN. CLIN = CLINOPTILOLITE; ILL1 = ILLITE SITE I; ILL2 = ILLITE SITE II; ILL3 = ILLITE SITE III ; SMEC $=$ SMECTITE; CALC $=$ CALCITE. 38

FIGURE 17. SPATIAL DISTRIBUTION AND CESIUM ASSOCIATIONS WITH MINERALS IN COLUMN EXPERIMENT \#1 (U-1A ALLUVIUM). LINES REPRESENT THE FIT TO DATA USING OUR MECHANISTIC MODEL AND REACTION CONSTANTS AND MINERAL REACTIVITIES DEFINED IN APPENDIX E. SPATIAL DISTRIBUTION AT 65 PORE VOLUMES IS SHOWN. CLIN = CLINOPTILOLITE; ILL1 = ILLITE SITE I; ILL2 = ILLITE SITE II; ILL3 = ILLITE SITE III ; SMEC $=$ SMECTITE.

FIGURE 18. CATIONS OCCUPYING ION EXCHANGE SITES ON ILLITE IN COLUMN EXPERIMENT \#1 (U-1A ALLUVIUM). LINES REPRESENT THE FIT TO DATA USING OUR MECHANISTIC MODEL AND REACTION CONSTANTS AND MINERAL REACTIVITIES DEFINED IN APPENDIX E. Spatial distribution at 65 PORE VOlumes is SHOWn. Solid Lines REPRESENT THE ION EXCHANGE SITE THAT PREFERENTIALLY SORBS CESIUM. OTHER SITES ARE REPRESENTED BY LONG-DASHED AND SHORT-DASHED LINES.

FigurE 19. RESUltS OF SIMS ANALYSIS OF COLUMN EXPERIMENT \#1 (U-1 A ALLUVIUM, 275 PORE VOLUMES). THICK LINES REPRESENT THE FIT TO DATA USING OUR MECHANISTIC MODEL AND REACTION CONSTANTS AND MINERAL REACTIVITIES DEFINED IN APPENDIX E (CS LINE DASHED TO REVEAL OTHER DATA FIT). THIN LINES REPRESENT MODEL FITS USING ADJUSTED CONSTANTS DEFINED IN TABLE 9. 41

Figure 20. BREAKTHROUGH DATA FOR EXPERIMENT \#2 (U-1 A ALLUVIUM). THICK LINES REPRESENT THE FIT TO DATA USING OUR MECHANISTIC MODEL AND REACTION CONSTANTS AND MINERAL REACTIVITIES DEFINED IN APPENDIX E. THIN LINES REPRESENT MODEL FITS USING ADJUSTED CONSTANTS DEFINED IN TABLE 9. 
Figure 21. IODIDE BREAKTHROUGH DATA FOR EXPERIMENT \#2 (U-1A ALLUVIUM), 0 TO 4 PORE VOLUME RANGE. LINES REPRESENT PREDICTED BREAKTHROUGH BASED ON THE GIMRT AND OS3D MODELS AND SEVERAL DISPERSIVITIES. 42

FIGURE 22. IODIDE BREAKTHROUGH DATA FOR EXPERIMENT \#2 (U-1A ALLUVIUM), 58 TO 63 PORE VOLUME RANGE. LINES REPRESENT PREDICTED BREAKTHROUGH BASED ON THE GIMRT MODELS AND A DISPERSION OF 0.01 METERS. 42

Figure 23. BREAKTHROUGH DATA FOR EXPERIMENT \#3 (UE-5N ALLUVIUM). THICK LINES REPRESENT THE FIT TO DATA USING OUR MECHANISTIC MODEL AND REACTION CONSTANTS AND MINERAL REACTIVITIES DEFINED IN APPENDIX E. THIN LINES REPRESENT MODEL FITS USING ADJUSTED CONSTANTS DEFINED IN TABLE 9. 43

FIGURE 24. IODIDE AND URANIUM BREAKTHROUGH DATA FOR EXPERIMENT \#3 (UE-5N ALLUVIUM), 0 TO 10 PORE VOLUME RANGE. THICK LINES REPRESENT THE FIT TO DATA USING OUR MECHANISTIC MODEL AND REACTION CONSTANTS AND MINERAL REACTIVITIES DEFINED IN APPENDIX E. THIN LINES REPRESENT MODEL FITS USING ADJUSTED CONSTANTS DEFINED IN TABLE 9

FIGURE 25. IODIDE AND URANIUM BREAKTHROUGH DATA FOR EXPERIMENT \#3 (UE-5N ALLUVIUM), 88 TO 100 PORE VOLUME RANGE. THICK LINES REPRESENT THE FIT TO DATA USING OUR MECHANISTIC MODEL AND REACTION CONSTANTS AND MINERAL REACTIVITIES DEFINED IN APPENDIX E. THIN LINES REPRESENT MODEL FITS USING ADJUSTED CONSTANTS DEFINED IN TABLE 9.

Figure 26. STRONTIUM BREAKTHROUGH DATA FOR EXPERIMENT \#3 (UE-5N ALLUVIUM). THICK LINES REPRESENT THE FIT TO DATA USING OUR MECHANISTIC MODEL AND REACTION CONSTANTS AND MINERAL REACTIVITIES DEFINED IN APPENDIX E. THIN LINES REPRESENT MODEL FITS USING ADJUSTED CONSTANTS DEFINED IN TABLE $9 . . .44$

Figure 27. BREAKTHROUGH DATA FOR EXPERIMENT \#4 (UE-5N ALLUVIUM). THICK LINES REPRESENT THE FIT TO DATA USING OUR MECHANISTIC MODEL AND REACTION CONSTANTS AND MINERAL REACTIVITIES DEFINED IN APPENDIX E. THIN LINES REPRESENT MODEL FITS USING ADJUSTED CONSTANTS DEFINED IN TABLE 9.

FIGURE 28. PREDICTED PROFILE OF NEPTUNIUM DISTRIBUTION AT 60 PORE VOLUMES FOR EXPERIMENT \#4 (UE-5N ALLUVIUM). THICK LINES REPRESENT THE FIT TO DATA USING OUR MECHANISTIC MODEL AND REACTION CONSTANTS AND MINERAL REACTIVITIES DEFINED IN APPENDIX E. THIN LINES REPRESENT MODEL FITS USING ADJUSTED CONSTANTS DEFINED IN TABLE 9.

FIGURE 29. IODIDE AND NEPTUNIUM BREAKTHROUGH DATA FOR EXPERIMENT \#4 (UE-5N ALLUVIUM), 0 TO 20 PORE VOLUME RANGE. THICK LINES REPRESENT THE FIT TO DATA USING OUR MECHANISTIC MODEL AND REACTION CONSTANTS AND MINERAL REACTIVITIES DEFINED IN APPENDIX E. THIN LINES REPRESENT MODEL FITS USING ADJUSTED CONSTANTS DEFINED IN TABLE 9

FIGURE 30. IODIDE AND NEPTUNIUM BREAKTHROUGH DATA FOR EXPERIMENT \#4 (UE-5N ALLUVIUM), 55 TO 90 PORE VOLUME RANGE. THICK LINES REPRESENT THE FIT TO DATA USING OUR MECHANISTIC MODEL AND REACTION CONSTANTS AND MINERAL REACTIVITIES DEFINED IN APPENDIX E. THIN LINES REPRESENT MODEL FITS USING ADJUSTED CONSTANTS DEFINED IN TABLE 9

Figure 31. STRONTIUM BREAKTHROUGH DATA FOR EXPERIMENT \#4 (UE-5N ALLUVIUM). THICK LINES REPRESENT THE FIT TO DATA USING OUR MECHANISTIC MODEL AND 
REACTION CONSTANTS AND MINERAL REACTIVITIES DEFINED IN APPENDIX E. THIN

LINES REPRESENT MODEL FITS USING ADJUSTED CONSTANTS DEFINED IN TABLE 9 ... 47 


\section{LIST OF TABLES}

TABle 1. Mineral abUNDANCES OF U-1A AND UE-5N ALLUVIUM USED IN BATCH AND COLUMN FLOW-THROUGH EXPERIMENTS DETERMINED BY QUANTITATIVE XRD.........27

TABLE 2. COMPOSITION OF SOLUTION IN EQUILIBRIUM WITH U-1 A ALLUVIUM. ................ 28

TABLE 3. INITIAL ELEMENT CONCENTRATIONS OF CALCITE AND PH EQUILIBRATED U-1A

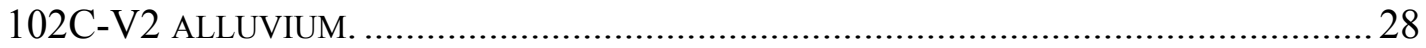

TABLE 4. KEY PARAMETERS FOR U-1A AND UE-5N ALLUVIUM FLOW-THROUGH EXPERIMENTS. 29

TABLE 5. SOLUTION CHEMISTRY OF SYNTHETIC FRENCHMAN FLAT WATER COMPARED TO AVERAGE MEASURED GROUNDWATER CHEMISTRY

TABLE 6. INITIAL SORBING ELEMENT AND TRACER CONCENTRATIONS IN SPIKED GROUNDWATER SOLUTIONS OF FLOW-THROUGH EXPERIMENTS.

TABLE 8. LOG K VALUES AND CATION EXCHANGE CAPACITIES REPRODUCED FROM TABLE 1 OF BROUWER ET AL. (1983)

TABLE 9. LIST OF PARAMETERS ADJUSTED TO FIT BATCH AND FLOW-THROUGH EXPERIMENTAL DATA. 30

TABLE A-1. FLOW-THROUGH EXPERIMENT \#1 DATA...................................................... 49

TABLE A-2. FLOW-THROUGH EXPERIMENT \#2 DATA....................................................5

TABLE A-3 FLOW-THROUGH EXPERIMENT \#3 DATA. ...................................................5

TABLE A-4 FLOW-THROUGH EXPERIMENT \#4 DATA. ...................................................55

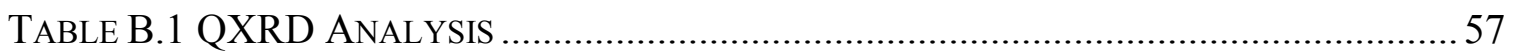

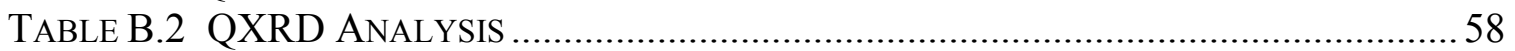

TABLE C-1. COARSE PARTICLE SIZE DETERMINATION OF U-1A.102C.V1 TO V5 SAMPLES.

TABLE C-2. ELEMENTAL ANALYSIS OF SATURATION PASTE EXTRACTS ${ }^{\dagger}$ OF U1A.102C.V1

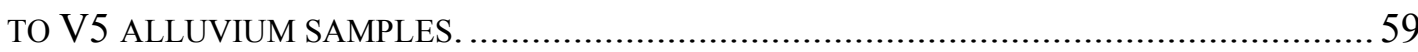

TABLE D-1. DATA FOR STRONTIUM (10 MG/L) SORPTION TO U-1A ALLUVIUM ..................60

TABLE D-2. DATA FOR STRONTIUM (1 MG/L) SORPTION TO U-1 A ALLUVIUM. .................... 61

TABLE D-3. DATA FOR CESIUM $(0.1 \mathrm{MG} / \mathrm{L})$ SORPTION TO U-1 A ALLUVIUM..........................62

TABLE D-4. DATA FOR EUROPIUM $(0.1 \mathrm{Mg} / \mathrm{L})$ SORPTION TO U-1 A ALLUVIUM. ....................63

TABLE D-5. DATA FOR SAMARIUM (0.1 MG/L) SORPTION TO U-1 A ALLUVIUM. .................64

TABLE E-1. RADIONUCLIDE-MINERAL INTERACTIONS DESCRIBED BY NON-ELECTROSTATIC

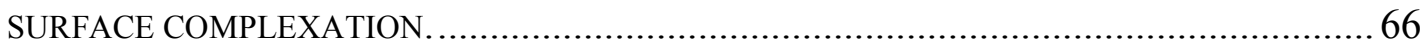

TABLE E-2. RADIONUCLIDE-MINERAL INTERACTIONS DESCRIBED BY VANSELOW ION

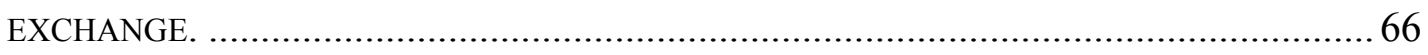

TABLE E-3. SURFACE COMPLEXATION REACTION FOR IRON OXIDES USING THE NON-

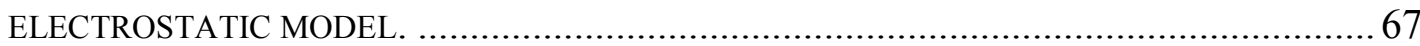

TABLE E-4. SuRfaCe COMPLEXATION REACTIONS FOR CALCITE USING THE NONELECTROSTATIC MODEL.

TABLE E-5. SURFACE COMPLEXATION REACTIONS FOR ALUMINOSILICATES USING THE

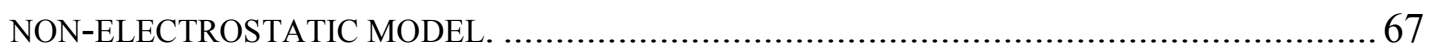

TABLE E-6. VANSELOW ION EXCHANGE REACTIONS FOR SMECTITE, MICA, AND CLINOPTILOLITE. 
TABLE E-7. PARAMETERS USED TO DEFINE REACTIONS ON MINERAL SURFACES. ..............6 68

TABLE E-8. BASIS SPECIES USED IN CRUNCH THERMODYNAMIC DATABASE. ..................69

TABLE E-9. PARAMETERS IN EXTENDED DEBYE-HUCKEL ACTIVITY COEFFICIENT MODEL AS

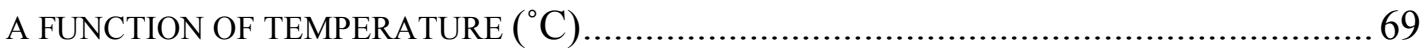

TABLE E-10. LOGARITHM OF EQUILIBRIUM CONSTANTS (K) OF AQUEOUS REACTIONS USED IN CRUNCH THERMODYNAMIC DATA BASE. ................................................. 70

TABLE F-1. ANALYSIS OF SELECTED ISOTOPE CONCENTRATIONS FOR COLUMN EXPERIMENT

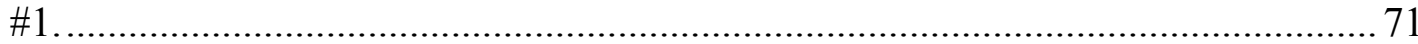

TABLE F-2. ANALYSIS OF TOTAL RADIONUCLIDE ELEMENT CONCENTRATIONS FOR COLUMN EXPERIMENT \#1. 


\section{Introduction}

The Underground Test Area (UGTA) program strategy requires model results to be validated. Our near-field hydrologic source term (HST) model at Frenchman Flat (Pawloski et al., 2000; Tompson et al., 1999; Tompson et al., 2001) employs a mechanistic surface complexation/ion exchange model to account for radionuclide sorption. Validation of this mechanistic model is a critical aspect of near-field HST validation. Since near-field HST calculations provide a source term for large-scale corrective action unit (CAU) model contaminant boundary calculations, this validation effort is also critical to the UGTA mission as a whole.

In an earlier report (Zavarin, 2001), we discussed how the mechanistic sorption model used in near-field HST simulations can be upscaled (or linked) to a linear $K_{d}$ model used in large-scale CAU simulations. In that report, we also attempted to validate the mechanistic model by comparing predicted sorption based on radionuclide sorbing mineral $^{1}$ abundance and water chemistry data with a small number of measured batch sorption data. However, the measured batch sorption data were woefully inadequate. To support our mechanistic sorption model validation effort, we collected new flow-through reactive transport data in FY2001. We report on these data below. We also report on batch sorption data collected in FY1999 but not published previously. The combination of flow-through and batch sorption data are used to partially validate our mechanistic porous flow radionuclide retardation model.

Flow-through column experiments were performed on Nevada Test Site (NTS) alluvium collected from wells UE-5n (Frenchman Flat) and U-1a (Yucca Flat). UE-5n alluvium was chosen due to its proximity to the Cambric test, where we first modeled a HST in alluvium (Pawloski et al., 2000; Tompson et al., 1999). U-1a alluvium was chosen because alluvium samples were characterized for a previous project, and the U-1a complex offered direct observation of in situ alluvium. Using samples from these two sites also allowed for a comparison of sorption in alluvium from Yucca Flat and Frenchman Flat and addressed the question of model parameter transferability. ${ }^{2}$ If the mechanistic model is appropriately based on thermodynamic principles, it should accurately predict the behavior of the radionuclide sorbing minerals regardless of their origin. Mechanistic sorption model parameter transferability is further discussed in Section 3.2.

Flow-through column experiments were performed using selected sorbing elements (cesium, strontium, samarium, neptunium, and uranium) and an iodide tracer

\footnotetext{
1 Radionuclide sorbing minerals are defined by our mechanistic sorption model to include iron oxide, smectite, zeolite (clinoptilolite), calcite, and illite/mica. While other minerals may also contribute to sorption, they are not included, at present, in our model and are, therefore, treated as non-sorbing minerals.

2 By transferability, we are relating to a basic issue of concern to the UGTA program. Due to data limitations, inputs to model simulations often must rely on data from outside the modeling domain which are thought to be transferable to the model domain because of geologic or hydrologic similarities. Here, we discuss only the transferrability of mechanistic sorption model parameters (mineral reactive surface areas, reactivities, etc.).
} 
representative of a range of radionuclide retardation behavior and a variety of dominant sorption mechanisms. ${ }^{3}$ For example, cesium is expected to sorb strongly to mica while uranium is expected to sorb primarily (but rather weakly) to iron oxide. Our choice of elements resulted in a wide range of retardation behavior that would best validate our mechanistic approach.

In addition to the flow-through experiments, we report on batch experiments performed on U-1a alluvium in FY1999. Batch sorption experiments were performed using cesium, strontium, samarium, and europium. The retardation behavior of cesium, strontium and samarium in batch experiments can be compared to cesium, strontium, and samarium flow-through experiments. Europium and samarium batch sorption experiments can be compared to evaluate similarities in behavior of rare earth elements. The batch sorption data provide additional validation to our mechanistic approach.

We used the mechanistic non-electrostatic surface complexation and Vanselow ion exchange models to predict sorption in our batch and flow-through experiments. This same approach was used in near-field HST calculations (see Pawloski et al. (2001)). The details of the mechanistic sorption model have been reported elsewhere (Zavarin and Bruton, 2000a; Zavarin and Bruton, 2000b) and will not be reiterated here. However, a summary of all parameters used in our mechanistic model is attached as Appendix E.

\section{Experimental Methods and Modeling Approach}

Below, we describe the materials and methods used in the three principal efforts of this report:

- Batch strontium, cesium, samarium, and europium sorption experiments on U-1a alluvium;

- Flow-through iodide, strontium, cesium, samarium, neptunium, and uranium experiments on U-1a and UE-5n alluvium;

- Modeling batch and flow-through data using the mechanistic approach developed for near-field HST calculations.

In Section 3 of this report, we discuss the experimental data and modeling results in an attempt to validate our mechanistic approach. Final conclusions are presented in Section 4 , and improvements to our mechanistic model based on these data are enumerated in Section 5 .

\footnotetext{
3 Except for uranium and neptunium, we used stable isotopes of the sorbing elements. The chemistry of the stable isotope of an element is equivalent to the chemistry of the respective radioactive isotope. Since the stable isotopes could be handled more readily in the lab, we used them whenever possible. The radioactive isotopes of all elements chosen for these experiments are part of the radiologic source term (Tompson et al., 2001).
} 


\subsection{Mineralogic characterization of $U-1$ a and $U E-5 n$ alluvium}

Mineralogic characterization of the alluvium used in batch sorption and flow-through experiments was accomplished by quantitative x-ray diffraction (XRD) at Los Alamos National Laboratory (LANL). The raw data were reported in a LANL internal memo by Steve Chipera and are included in this report as Appendix B.

The U-1a alluvium was taken from an exposed section of the $\mathrm{C}$ alcove of the $\mathrm{U}-1 \mathrm{a} .102$ drift. The sampling and initial petrographic analysis of alluvium from this alcove was performed in FY1999 for the UGTA program and reported in Rose et al. (1999). The sample used in batch and flow-through experiments was U-1a.102C-V2 but is simply referred to as $\mathrm{U}-1 \mathrm{a}$ alluvium in much of this report. The sample is dominated by sand and silt, is well indurated, and is cross-cut with a significant number of veinlets formed by precipitation of calcite. X-ray diffraction and semi-quantitative energy dispersive spectra analyses of Rose et al. (1999) suggest that kaolinite is the dominant clay mineral, although smectite is widespread in lower abundance. However, quantitative XRD results of Chipera (Table 1) suggest the opposite: smectite is the dominant clay with significant but less kaolinite. This discrepancy has not been accounted for but the quantitative nature of the analysis of Chipera suggests that these values are more accurate. We use the Chipera quantitative data in our model validation effort.

Flow-through experiments using UE-5n alluvium were performed using a 1:1 mix of alluvium from the 1140 and 1160 foot depths (labeled UE5N-1140 and UE5N-1160 in Appendix B). A mixture was used due to a limited sample supply. An average composition for these two samples is reported in Table 1. It is instructive to compare the abundance of radionuclide sorbing minerals in the $\mathrm{U}-1 \mathrm{a}$ and $\mathrm{UE}-5 \mathrm{n}$ alluvium samples. When compared to $\mathrm{U}-1$ a alluvium, the composite $\mathrm{UE}-5 \mathrm{n}$ alluvium sample contains significantly more zeolite (clinoptilolite), less smectite, less calcite, and more iron oxide (iron oxide was not detectable in $\mathrm{U}-1 \mathrm{a}$ alluvium). The quantity of biotite is equivalent in U-1a and UE-5n alluvium. ${ }^{4}$ Given their difference in radionuclide sorbing mineral abundances, we would expect the radionuclide retardation behavior of these two samples to be significantly different. Our mechanistic model should be able to predict these differences because, in principal, the model accounts for the effect of water chemistry, radionuclide concentration, and radionuclide sorbing mineral abundance on radionuclide retardation. See Pawloski et al. (2001) for further details on the mechanistic model.

\subsection{FY1999 batch sorption experiments}

Batch experiments were performed in FY1999 on one U-1a alluvium sample (102C-V2, Appendix B). However, some characterization of $\mathrm{U}-1$ a alluvium included a set of five alluvium samples (102C.V1 to 102C.V5). The specific sampling position of these samples is discussed in Rose et al. (1999). While all these initial characterization data will not be discussed here, data collected on these samples and not reported previously

\footnotetext{
${ }^{4}$ In the quantitative XRD analysis of Chipera, the abundances of illite and mica were summed and labeled biotite.
} 
are included in Appendix C. Lithologic, mineralogic, and petrographic characterization in Rose et al. (1999) also includes these samples.

Batch sorption experiments were performed over a $\mathrm{pH}$ range of 7.5 to 9.5 , under atmospheric $\mathrm{CO}_{2}(\mathrm{~g})$ equilibrium conditions, and at room temperature using U-1a alluvium. This $\mathrm{pH}$ range was chosen to a) bound the observed ambient $\mathrm{pH}$ of Frenchman Flat and Yucca Flat waters b) evaluate whether $\mathrm{pH}$ changes in the near-field may alter sorption behavior of radionuclides and c) to evaluate our mechanistic approach over a range of fluid compositions. A wider range of solution conditions would more thoroughly test our mechanistic model. However, it would also drastically complicate the interpretation of data. For example, if lower $\mathrm{pHs}$ were included, calcite would dissolve and the change in alluvium mineralogy would have to be taken into account. In fact, careful attention was taken to ensure that minimal changes in the water chemistry and mineralogy occurred across the $\mathrm{pH}$ range of the batch experiments. A multi-step process was necessary to prepare the batch sorption solutions. Nine $500 \mathrm{~mL}$ solutions were prepared that ranged from $\mathrm{pH} 7.5$ to $\mathrm{pH} 9.5$. Each solution was prepared by starting with a solution composition based on a saturated soil paste extract (Table 2$){ }^{5}$ The $\mathrm{Ca}^{2+}$ composition was then adjusted $\left(\mathrm{CaCl}_{2}\right.$ solution) to equilibrium with calcite at the prescribed $\mathrm{pH}$ and assuming a $\mathrm{HCO}_{3}{ }^{-}$concentration as defined by solutions equilibrium with atmospheric $\mathrm{CO}_{2}(\mathrm{~g})$. The $\mathrm{pH}$ was adjusted using either $\mathrm{HCl}$ or $\mathrm{Na}_{2} \mathrm{CO}_{3}$ and solutions were bubbled with air to achieve equilibrium with atmospheric $\mathrm{CO}_{2}(\mathrm{~g})$. During solution preparation, the $\mathrm{pH}$ of the solution was maintained using $\mathrm{pH}$-stat equipment. When $\mathrm{CO}_{2}(\mathrm{~g})$ saturation was approached, a small amount of calcite $(0.05 \mathrm{~g})$ was added to the solution to ensure calcite equilibrium. Finally, 25 grams of U-1a alluvium was added to ensure that the solution was at equilibrium with alluvium mineralogy. Calcite and $\mathrm{CO}_{2}(\mathrm{~g})$ equilibrium was assumed to have been achieved once the $\mathrm{pH}$ of the solutions remained constant. Thus, nine solutions in equilibrium with calcite, atmospheric $\mathrm{CO}_{2}(\mathrm{~g})$, and the U-1a alluvium and resembling the solution composition at equilibrium with U-1a alluvium (Table 2) were prepared. Prior to use in sorption experiments, these solutions were filtered through $0.5 \mu \mathrm{m}$ filters.

The compositions of the nine solutions used in batch sorption experiments are listed in Table 3. Significant differences in initial solution composition for the nine sorption solutions exist. These differences result, in large part, from the ion exchange behavior of the alluvium and the significant change in $\mathrm{Ca}^{2+}$ concentration imposed on the alluvium as a result of $\mathrm{pH}$ adjustment and calcite saturation. The $\mathrm{Ca}^{2+}$ concentration increases significantly at low $\mathrm{pH}$ when in equilibrium with calcite. The high $\mathrm{Ca}^{2+}$ in solution results in significant removal of $\mathrm{Mg}^{2+}$ and $\mathrm{Sr}^{2+}$ from exchange sites. ${ }^{6}$ Concentration of these ions increase as the $\mathrm{pH}$ decreases. The $\mathrm{Na}^{+}$concentration increases at high $\mathrm{pH}$ as $\mathrm{Na}_{2} \mathrm{CO}_{3}$ is used for $\mathrm{pH}$ adjustment.

\footnotetext{
5 A saturated soil paste extract is routinely used in soil science to evaluate the composition of soil water under the condition of soil saturation. A saturated soil paste is prepared by adding water to a sample of soil until the soil paste glistens as it reflects light, flows slightly when the container is tipped, and the paste slides freely and cleanly from a spatula. Typically, this occurs near the 1:1 soil to water volume ratio. 6 Note that this would occur for $\mathrm{Na}^{+}$as well. However, its ion exchange behavior is obscured by $\mathrm{pH}$ adjustment with $\mathrm{Na}_{2} \mathrm{CO}_{3}$.
} 
Five sets of batch sorption experiments were performed over the entire $\mathrm{pH} 7.5$ to 9.5 range using the nine prepared batch sorption solutions. Each set of sorption experiments was performed using a single sorbing element $(\mathrm{Sr}, \mathrm{Cs}, \mathrm{Eu}$, or $\mathrm{Sm})$. The five sets of sorption experiments were the following: $10 \mathrm{mg} / \mathrm{L}$ strontium as $\mathrm{Sr}^{2+}, 1 \mathrm{mg} / \mathrm{L}$ strontium as $\mathrm{Sr}^{2+}, 0.1 \mathrm{mg} / \mathrm{L}$ cesium as $\mathrm{Cs}^{+}, 0.1 \mathrm{mg} / \mathrm{L}$ europium as $\mathrm{Eu}^{3+}$, and $0.1 \mathrm{mg} / \mathrm{L}$ samarium as $\mathrm{Sm}^{3+}$. Batch sorption experiments were performed in duplicate and with a parallel blank. For each batch sorption experiment, $30 \mathrm{~mL}$ solution and $1.5 \mathrm{~g}$ alluvium were added to a Teflon tube and allowed to equilibrate for two days ( $\mathrm{pH}$ was adjusted if necessary). For sorption samples, a sorbing element was then added to the Teflon tube using 15 to $30 \mu \mathrm{L}$ of a concentrated salt solution spike $\left(\mathrm{SrCl}_{2}, \mathrm{CsCl}, \mathrm{Eu}_{2}\left(\mathrm{SO}_{4}\right)_{3}\right.$, or $\left.\mathrm{Sm}_{2}\left(\mathrm{SO}_{4}\right)_{3}\right)$. For blanks, alluvium was filtered out after the 2 day equilibration, an aliquot of solution was reserved for analysis (non-spiked blank), and remaining filtered solution was then spiked with the sorbing element (spiked blank). The elements were allowed to sorb for 2-10 days at which time the samples were centrifuged and filtered with $0.2 \mu \mathrm{m}$ filters, the $\mathrm{pH}$ measured and, finally, the solutions acidified with $\mathrm{HCl}$ for later analysis using inductively coupled plasma mass spectrometry (ICP-MS). Solutions were analyzed for $\mathrm{Na}, \mathrm{K}, \mathrm{Ca}$, $\mathrm{Mg}, \mathrm{Cs}, \mathrm{Sr}, \mathrm{Sm}$, and Eu. All reagents were American Chemical Society (ACS) certified. The raw data are listed in Appendix D.

\subsection{FY2001 flow-through experiments}

Four flow-through experiments were performed: two using U-1a alluvium and two using UE-5n alluvium. Each experiment was performed using flow-through column equipment depicted in Figure 1. Fluids of known composition (measured analytically) were pumped from a large polypropylene bottle through a peristaltic pump and vertically upwards through the polyacrylic columns filled with disaggregated alluvium. ${ }^{7}$ Outflow samples were collected in tubes on a fraction collector.

For each experiment, the alluvium density, the dimensions of the column, the mass of alluvium contained in the column, the volume of all tubing used along the flow path from the solution reservoir to the fraction collector, and the flow rates were measured. Some of the pertinent data are listed in Table 4; other data are listed in Appendix A. The pore volume and porosity were derived from the measured column volume, alluvium density, and alluvium mass. The pore volume data listed in Table 4 were calculated by subtracting the alluvium volume from the column volume and adding the volume of tubing between the solution reservoir and column $(\sim 1.5 \mathrm{~mL})$ and between the column and the fraction collector $(\sim 0.5 \mathrm{~mL})$. In this manner, a tracer would be expected to break through at exactly one pore volume. Column dimensions were typically $15 \mathrm{~cm}$ long with a $1 \mathrm{~cm}$ diameter. The density of the alluvium was measured using a Quantachrome Corporation multipycnometer. The multipycnometer determines the density of powder samples by measuring the pressure difference when a known quantity of helium under pressure is allowed to flow from a precisely known reference volume into a sample cell containing the powder material.

\footnotetext{
7 In the first flow-through experiment, a syringe pump was used instead of the peristaltic pump. This difference did not affect our results in any way.
} 
The fluid used in all flow-through experiments (Table 5) was the same and based on Frenchman Flat alluvium groundwater chemistry data provided by T. P. Rose of LLNLANCD (Rose, 2001). ${ }^{8}$ The Frenchman Flat alluvium groundwater chemistry of T.P. Rose is similar to that reported in IT (1999). The synthesized Frenchman Flat groundwater was equilibrated with calcite to ensure that calcite dissolution/precipitation reactions did not occur during experiments. Also, the concentration of silica was deliberately lower than typically observed to reduce the likelihood of forming silica precipitates on the surfaces of minerals during experiments. The flow rates in column experiments ranged from 0.1 to $0.13 \mathrm{~mL} / \mathrm{min}$; the fluid residence time ranged from 35 minutes to 1 hour.

Flow-through experiments were performed by: (1) initially equilibrating the column with flowing synthetic Frenchman Flat alluvium groundwater for several days; (2) flowing synthetic Frenchman Flat alluvium groundwater spiked with several sorbing elements and a tracer for several days; and (3) flowing non-spiked groundwater for approximately 10 additional days to force the spiked fluid through the column. This produced a very long contaminant pulse that traveled through each column. The composition of the synthetic groundwater is listed in Table 5. The concentrations of the sorbing elements and tracer in the spiked synthetic groundwater for each experiment is listed in Table 6 . The sorbing element and tracer concentrations for each experiment were similar except that either neptunium or uranium (but not both) was used in a single flow-through experiment. Uranium and neptunium could not be run in combination because of isotope interference effects in the secondary ion mass spectrometry (SIMS) analysis, described below. However, duplication of all other sorbing elements in the experiments allowed us to check for experiment reproducibility.

During each experiment, fluid from the end of the alluvium column was collected with an automated fraction collector. When tracking the breakthrough of the tracer (iodide), $\sim 1$ $\mathrm{mL}$ samples were taken continuously. At later times, $\sim 10 \mathrm{~mL}$ samples were collected. The iodide tracer breakthrough was measured using an ion specific electrode. The neptunium breakthrough was measured using a scintillation counter. All other elements were measured using inductively coupled plasma mass spectrometry. For some columns, $\mathrm{pH}$ and carbonate alkalinity were measured as well. Carbonate alkalinity was measured using a standard $\mathrm{CO}_{2}$ analyzer with an infra-red detector; only small changes in carbonate alkalinity or $\mathrm{pH}$ were detected during flow-through experiments. In all reactive transport model simulations, it was assumed that the background solution composition was constant and equivalent to the initial solution composition.

\footnotetext{
${ }^{8}$ Note that the composition of Frenchman Flat water (Table 5) is similar to that in equilibrium with in-situ U-1a alluvium (Table 2). For simplicity, we used synthetic Frenchman Flat water in both U-1a and UE-5n flow-through experiments.
} 


\subsection{Secondary ion mass spectrometry (SIMS) analysis of flow-through experiments}

SIMS analysis was performed on one column after the completion of the flow-through experiment. ${ }^{9}$ The purpose of the SIMS analysis was to examine the migration of those elements that did not travel the entire length of the column (i.e., highly retarded elements such as samarium).

To prepare for SIMS analysis, the column was removed from the flow-through apparatus and oven dried at $60^{\circ} \mathrm{C}$ at the completion of the flow-through experiment. EPO-TEC 301 epoxy was pulled through the alluvium-filled column by vacuum. After approximately thirty minutes, the alluvium was completely saturated with epoxy. The column was allowed to cure for twenty-four hours at room temperature, after which the column was cut into seven or eight pieces along the entire length of the column using a low speed Isomet saw with a diamond impregnated saw blade cooled with de-ionized (DI) water. Each $\sim 2 \mathrm{~cm}$ length column sections was then cut in half along the column flow direction. One of the halves from each of the seven or eight column sections was then mounted to a 1 inch round-mount with epoxy. Each of the mounted sections was then cut so that a 2 $\mathrm{mm}$ thick section remained on the glass mount. Finally, the surface of each section was ground using 400, 600, 800 and 1200 grit silicon carbide grinding paper. The sample surface was also polished using $1.0 \mu \mathrm{m}, 0.5 \mu \mathrm{m}$, and finally $0.05 \mu \mathrm{m}$ alumina polishing powder on a soft polishing cloth. Each section was placed in an ultrasonic bath with DI water for fifteen minutes to remove polishing residue. Figure 2 shows an example of one entire column length prepared for SIMS analysis.

Concentrations of trace elements in the column sections were measured with a modified CAMECA IMS-3f SIMS at Lawrence Livermore National Laboratory, Analytical \& Nuclear Chemistry Division (ANCD). Secondary ions were generated by sample bombardment with a $10 \mathrm{nA}^{16} \mathrm{O}^{-}$primary beam with a net energy of $17 \mathrm{keV}$. Analysis typically involved rastering a focused ion beam over a $100 \times 100 \mu \mathrm{m}$ area centered on the point of interest. To suppress molecular interferences, an energy filtering technique was used (Shimizu et al., 1978; Zinner and Crozaz, 1986). This involved offsetting the +4.5 $\mathrm{kV}$ secondary ion accelerating voltage by $-80 \mathrm{~V}$ relative to the voltage at which the ${ }^{30} \mathrm{Si}^{+}$ intensity decreased to $10 \%$ of its maximum value on the low-energy side. Signals were collected on an electron-multiplier detector, and a correction was applied for countingsystem deadtime. Each analysis consisted of 10 cycles through 23 masses that targeted natural isotopes of strontium, cesium, samarium, and uranium, along with possible isobaric interferences. Data were also collected for selected masses corresponding to "major" elements $(\mathrm{Na}, \mathrm{Al}, \mathrm{K}, \mathrm{Ca}, \mathrm{Fe})$ to provide a qualitative indicator of heterogeneities in the matrix composition. A compilation of the data is tabulated in Appendix F.

Secondary-ion intensities measured on "unknown" materials are quantified by comparison with a standard material of known trace element chemistry that has a major element composition similar to that of the unknown (Hinton et al., 1995). Analytical

\footnotetext{
${ }^{9}$ Although only one column analysis was completed, all four flow-through columns were prepared for SIMS analysis and could be run at a later date.
} 
precision is improved by measuring the ratio of the peak intensity of the element of interest to that of a major species $\left({ }^{30} \mathrm{Si}^{+}\right)$. Concentrations (in ppm or $\mathrm{mg} / \mathrm{kg}$ ) are calculated from measured ion intensity ratios using the following relationship:

$$
\left.[\mathrm{X}]_{\mathrm{Sa}}=\left[\frac{\left(\frac{[\mathrm{X}]_{\mathrm{ppm}}}{\left[{ }^{30} \mathrm{Si}\right]_{\mathrm{ppm}}}\right)_{\mathrm{std}}}{\left(\frac{I\left(\mathrm{X}^{+}\right)}{I\left({ }^{30} \mathrm{Si}^{+}\right)}\right)_{\text {std }}}\right] \times\left[\frac{I\left(\mathrm{X}^{+}\right)}{I\left({ }^{30} \mathrm{Si}^{+}\right)}\right]_{\mathrm{Sa}} \times{ }^{30} \mathrm{Si}\right]_{\mathrm{Sa}}
$$

where $[\mathrm{X}]_{\mathrm{sa}}$ is the concentration $(\mathrm{ppm}$ or $\mathrm{mg} / \mathrm{kg}$ ) of the species of interest in the sample matrix; $\left([\mathrm{X}]_{\mathrm{ppm}} /\left[{ }^{30} \mathrm{Si}\right]_{\mathrm{ppm}}\right)_{\mathrm{std}}$ is the ratio of concentration of the species of interest to that of ${ }^{30} \mathrm{Si}$ in the reference standard; $\left(I\left(\mathrm{X}^{+}\right) / I\left({ }^{30} \mathrm{Si}^{+}\right)\right)_{\text {std }}$ is the measured ion intensity ratio of species $\mathrm{X}$ relative to that of ${ }^{30} \mathrm{Si}$ in the reference standard; $\left(I\left(\mathrm{X}^{+}\right) / I\left({ }^{30} \mathrm{Si}^{+}\right)\right)_{\mathrm{sa}}$ is the measured ion intensity ratio of species $X$ relative to that of ${ }^{30} \mathrm{Si}$ in the sample; and $\left[{ }^{30} \mathrm{Si}\right]_{\mathrm{sa}}$ is the concentration of ${ }^{30} \mathrm{Si}$ in the sample matrix. The reference material used during this study was NIST standard reference material 612, a silicate glass containing known concentrations of 61 trace elements. Average trace element abundances of strontium, cesium, samarium, and uranium in NBS-612 are 77.6 $\pm 0.8,39.7 \pm 4.0,37.4 \pm 1.1,37.3 \pm$ $0.1 \mathrm{mg} / \mathrm{kg}$, respectively.

To calculate the concentration of any given species from the ion intensity data, we must first determine the ${ }^{30} \mathrm{Si}$ content of the sample matrix. Ideally, this is achieved by measuring the $\mathrm{SiO}_{2}$ abundance with an electron microprobe at each location where ion probe data were acquired. However, since the main objective of the ion probe analyses is to elucidate the spatial distribution of trace elements in the alluvium, we can simply estimate the matrix ${ }^{30} \mathrm{Si}$ concentration from the weighted mean $\mathrm{SiO}_{2}$ concentrations of the dominant mineral constituents, as determined by quantitative XRD data. Normalized to $100 \mathrm{wt} . \%$, the U-1a alluvial matrix contains approximately $37.5 \mathrm{wt} . \%$ smectite, $25 \mathrm{wt} . \%$ quartz, $12.5 \mathrm{wt} . \%$ volcanic glass, and $25 \mathrm{wt} . \%$ calcite. Multiplying each of these constituents by their average $\mathrm{SiO}_{2}$ concentrations and summing the products provides an estimate of the mean $\mathrm{SiO}_{2}$ concentration for $\mathrm{U}-1$ a alluvium (Table 7).

Assuming an average $\mathrm{SiO}_{2}$ concentration of $53.19 \mathrm{wt} . \%$, the mean ${ }^{30} \mathrm{Si}$ concentration is readily determined to be $\sim 7707 \mathrm{mg} / \mathrm{kg}$. In detail, this value will vary according to which minerals are dominant at the point of analysis. However, the approximate ${ }^{30} \mathrm{Si}$ value given here is sufficient to estimate trace element abundances to within $\sim 20 \%$ of their actual values.

Mass peaks corresponding to species of interest are often associated with isobaric interferences that cannot be eliminated by energy-filtering techniques. We have attempted to minimize these effects by selecting masses associated with relatively minor isobaric interferences. Total elemental concentrations are then determined by dividing the measured isotopic concentration by its natural abundance. In the case of strontium, ${ }^{88} \mathrm{Sr}$ was used to calculate total strontium since the main isobaric interference is from ${ }^{44} \mathrm{Ca}^{++}$, a minor isotope of calcium. Samarium concentrations were determined from 
${ }^{149} \mathrm{Sm}$, which has a nominal isobaric interference with the ${ }^{133} \mathrm{Cs}^{+}+{ }^{16} \mathrm{O}^{+}$dimer. Although cesium was added to the samples during the flow through experiments, alkali metal oxide dimers are not readily formed during ion beam sputtering. Both ${ }^{133} \mathrm{Cs}$ and ${ }^{238} \mathrm{U}$ are essentially free of isobaric interferences.

\subsection{Modeling batch and flow-through experiments}

Batch sorption and flow-through experiments were modeled using the CRUNCH reactive transport code (Steefel, 2000), an updated GIMRT/OS3D code (Steefel and Yabusaki, 1995). Non-electrostatic surface complexation and Vanselow ion exchange were used to predict sorption. Details regarding the reactive transport model and sorption reactions can be found in several recent UGTA reports (Pawloski et al., 2001; Tompson et al., 2001; Zavarin, 2001). All reaction constants and radionuclide sorbing mineral characteristics used to model the data presented in this report are tabulated in Appendix E. Any adjustments to these values that were required to improve the model fits to batch and flow-through experiments are noted in the text.

\section{Experiment results}

In the following sections, we present batch sorption and flow-through experiment data along with our mechanistic sorption model predictions. In all cases, two categories of simulations are presented. In the first, we use the water chemistry, sorbing mineral abundances, and the model parameters defined in Appendix E to predict the behavior of the sorbing elements. This modeling exercise is used to evaluate our modeling database in its present state. In the second, we attempt to improve the model fits to experimental data by adjusting certain sorption constants, reactive site concentrations, or other parameters. We justify the adjustments by citing published data or proposing a reasonable hypothesis for the unexpected behavior of the alluvium. The raw experimental data for all batch sorption and flow-through column experiments are listed in Appendices A, D, and F.

\subsection{Batch sorption experiments}

Before discussing the batch sorption results, it is worthwhile to define the terminology used to describe the various samples analyzed in these experiments. For each set of sorption experiments, blanks were run in parallel with sorption samples. In the case of the blanks, the initial solution refers to the calcite-atmospheric $\mathrm{CO}_{2}(\mathrm{~g})$-alluvium equilibrated solutions listed in Table 3. Once 1.5 grams alluvium are added to $30 \mathrm{~mL}$ of the initial solution, we refer to the solution as the non-spiked blank. Once the non-spiked blank is filtered and a spike is added to the solution, we refer to it as the spiked blank. In the case of the sorption sample solutions, the initial solution, again, refers to the calciteatmospheric $\mathrm{CO}_{2}(\mathrm{~g})$-alluvium equilibrated solutions listed in Table 3. Once 1.5 grams alluvium are added to $30 \mathrm{~mL}$ of the initial solution, we refer to it as the non-spiked sample. Once a spike is added to the non-spiked sample, we refer to it as the spiked sample. 


\subsubsection{Sorption of $10 \mathrm{mg} / \mathrm{L}$ strontium on $U-1$ a alluvium}

Figures 3 and 4 present experimental data and modeling results for $10 \mathrm{mg} / \mathrm{L}\left(1.1 \times 10^{-4}\right.$ $\mathrm{mol} / \mathrm{L}$ ) strontium sorption to $\mathrm{U}-1 \mathrm{a}$ alluvium. ${ }^{10}$ Figure 3 presents blank data. Blank data were used to evaluate the background strontium concentrations (non-spiked blanks) and determine the strontium concentration in solution after addition of the strontium spike (spiked blanks). The strontium concentration in the non-spiked blanks (blue squares) varies as a function of $\mathrm{pH}$ and is quite high. This results from two sources. First, the initial solution equilibrated with calcite, atmospheric $\mathrm{CO}_{2}(\mathrm{~g})$, and alluvium prior to the start of batch experiments (Table 3) contains a significant amount of strontium, particularly in low-pH samples. The high strontium in the low $\mathrm{pH}$ samples results from the high calcium introduced to solutions to retain calcite equilibrium which subsequently releases $\mathrm{Sr}$ from ion exchange sites. Second, a smaller quantity of strontium is released from ion exchange sites once the $\mathrm{U}-1$ a alluvium is introduced to the initial solutions. ${ }^{11}$ The concentration of strontium in the spiked blanks is significantly greater than in the non-spiked blanks. Thus, the spiked blank concentrations (yellow squares) are nearly constant over the entire $\mathrm{pH}$ range. The slight increase at low $\mathrm{pH}$ results from the strontium in the non-spiked blank (blue squares) while the decrease in spiked blank strontium at $\mathrm{pH} 9.5$ may have resulted from the slight over-saturation of the solution with respect to strontianite. ${ }^{12}$

Based on the non-spiked blank data presented in Figure 3 (blue squares), we can attempt to predict the sorbed + aqueous strontium in each non-spiked blank using our mechanistic model. These data are plotted as green circles in Figure 3. If we then subtract from this the amount of strontium in the initial solutions (Table 3), we arrive at the predicted sorbed + aqueous strontium associated with $\mathrm{U}-1 \mathrm{a}$ alluvium used in batch experiments (Figure 3, red circles). This amount of strontium should be constant as a function of $\mathrm{pH}$ since it is simply the amount of sorbed + aqueous strontium originally in the $\mathrm{U}-1$ a alluvium. The resulting predicted aqueous + sorbed strontium concentration in $\mathrm{U}-1 \mathrm{a}$ alluvium is $2.8 \times 10^{-5} \pm 0.7 \times 10^{-5} \mathrm{~mol} / \mathrm{kg}$ water (or $50 \pm 12 \mu \mathrm{g} / \mathrm{g}$ alluvium). This quantity is equivalent to $\sim 25 \%$ of the strontium spike. Due to this relatively high strontium background, this fraction of strontium must be accounted for when modeling the sorption data.

Figure 4 presents results for $10 \mathrm{mg} / \mathrm{L}$ strontium sorption to $\mathrm{U}-1 \mathrm{a}$ alluvium. The initial spiked sample strontium concentrations (yellow squares) are based on the sum of the non-spiked blank strontium (Figure 3, blue squares) and strontium spike concentrations. Below pH 7.5, strontium sorption is very weak (Figure 4) as a result of the high Ca concentrations in solution. As the $\mathrm{pH}$ increases, the $\mathrm{Ca}$ concentration decreases (as

\footnotetext{
${ }^{10}$ For convenience, measured data plotted in batch sorption figures in this report are always shown as colored squares. Predicted or calculated data are shown as circles.

${ }^{11}$ If initial solutions were equilibrated with a sufficiently large quantity of alluvium, we would expect that additional strontium release upon addition of alluvium during batch experiments would not have occurred. However, some release of strontium suggests that solutions were close to but not in complete equilibrium with the original ion exchange site composition of the U-1a alluvium.

${ }^{12}$ The longer equilibration time of the $\mathrm{pH} 9.5$ sample (see appendix D) may also have affected this result by increasing the likelihood of strontianite nucleation.
} 
prescribed by calcite saturation) while the $\mathrm{Na}$ concentration increases (as charge balance to the increased alkalinity from atmospheric $\mathrm{CO}_{2}(\mathrm{~g})$ saturation) (Figure 5). The change in strontium sorption as a function of $\mathrm{pH}$ results from the relative affinities of the cations for the ion exchange sites, as will be discussed below.

To model the sorption data, the total aqueous + sorbed strontium in the spiked samples was based on the sum of the strontium spike and the predicted aqueous + sorbed strontium in the non-spiked blanks (Figure 3, green circles). The model results based on our mechanistic model (Appendix E) are presented in red in Figure 4. Under these conditions, ion exchange on smectite is predicted to be the dominant strontium sorption mechanism over the entire $\mathrm{pH}$ range. In general, our mechanistic model slightly overpredicts the sorption of strontium to $\mathrm{U}-1$ a alluvium. The predicted aqueous strontium concentration is $\sim 30 \%$ lower than measured. In terms of retardation coefficient $\left(K_{d}\right.$, $\mathrm{mL} / \mathrm{g}$ ), the strontium sorption varies from 0 to $800 \mathrm{~mL} / \mathrm{g}$, generally increasing with $\mathrm{pH}$. At any one point, the predicted $K_{d}$ is $\sim 1.8$ times greater than the measured $K_{d}$, well within the range of uncertainty of our mechanistic reaction constants. The results suggests that our mechanistic model predicts strontium behavior remarkably well.

In principal, one could improve the match between measured and predicted aqueous strontium by adjusting the ion exchange constants or mineral characteristics used in our model. However, this is quite challenging because there are a number of parameters that may be adjusted to improve the fit. For example, a data fit using an effective cation exchange capacity that is reduced by $50 \%$ improves the data fit significantly (see Figure 4). However, one could also reduce the ion exchange constant for strontium on smectite and effect a similar improvement. Both methods can be justified with a variety of arguments. For example, the effective cation exchange capacity of smectite may be significantly less than originally estimated because secondary calcite in the alluvium may block access to some fraction of the smectite. Equivalently, the ion exchange constant for strontium was taken from Fletcher and Sposito (1989) who based their value on the assumption that strontium behaves similar to $\mathrm{Ca}$; clearly, there is some uncertainty in this assumption. Further details regarding improving our mechanistic model fit to the data will be elucidated in the following analyses of data.

\subsubsection{Sorption of $1 \mathrm{mg} / \mathrm{L}$ strontium on $\mathrm{U}-1$ a alluvium}

Figures 6 and 7 present experimental data and modeling results for $1 \mathrm{mg} / \mathrm{L}$ strontium sorption to U-1a alluvium. The format of these plots is identical to that used in the previous section. Again, we used the non-spiked blank data (Figure 6) to estimate the aqueous + sorbed strontium in U-la alluvium. The resulting predicted strontium concentration in U-1a alluvium is $2.7 \times 10^{-5} \pm 0.7 \times 10^{-5} \mathrm{~mol} / \mathrm{kg}$ water, nearly identical to the result presented in Section 3.1.1. The strontium spike $\left(1 \mathrm{mg} / \mathrm{L}\right.$ or $10^{-5} \mathrm{~mol} / \mathrm{L}$ water $)$ accounts for only $\sim 25 \%$ of the total aqueous + sorbed strontium in these sorption samples. Background strontium will, therefore, have a strong influence on final aqueous strontium concentrations in batch experiments and must be accounted for in model simulations. 
In Figure 7, we present both the sorption data and the model prediction results for the 1 $\mathrm{mg} / \mathrm{L}$ strontium sorption experiments. As in the $10 \mathrm{mg} / \mathrm{L}$ strontium sorption experiments, the initial spiked sample strontium (yellow squares) was calculated based on the sum of the strontium in the non-spiked blank (Figure 6, blue squares) and the strontium spike. In this case, measured $K_{d} \mathrm{~S}(\mathrm{~mL} / \mathrm{g})$ range from 3 to 900 and the predicted values differ from measured values by an average of $10 \%$ when using a smectite cation exchange capacity of $0.85 \mathrm{meq} / \mathrm{g}$. Our predicted strontium concentrations match the data equally well when using a $50 \%$ lower smectite cation exchange capacity. ${ }^{13}$ As in the $10 \mathrm{mg} / \mathrm{L}$ strontium sorption experiments, our mechanistic model predicts strontium sorption quite well.

\subsubsection{Sorption of $0.1 \mathrm{mg} / \mathrm{L}$ cesium on $\mathrm{U}-1$ a alluvium}

Figure 8 presents the $0.1 \mathrm{mg} / \mathrm{L}$ cesium batch sorption data and several model predictions. Because cesium concentrations in the U-1a alluvium are extremely low (Table 3 ), it was not necessary to account for the background concentration of cesium in model predictions. The spiked blank cesium concentration was constant $\left(\sim 7.7 \times 10^{-7} \mathrm{~mol} / \mathrm{L}\right)$ for all samples. Little or no loss of cesium to container walls was observed.

Upon reaction with $\mathrm{U}-1 \mathrm{a}$ alluvium, the cesium concentration in sorption samples decreased from $\sim 7.7 \times 10^{-7} \mathrm{~mol} / \mathrm{L}$ to less than $10^{-8} \mathrm{~mol} / \mathrm{L}$. The resulting $K_{d s}$ range from 1000 to $9000 \mathrm{~mL} / \mathrm{g}$ over the $\mathrm{pH}$ range examined here. As in the case of strontium, sorption was affected by the solution composition and, in particularly, the major cation chemistry. At low $\mathrm{pH}$, sorption was reduced as a result of increased competition for surface sites with $\mathrm{Ca}$. At high $\mathrm{pH}$, the reduction in sorption resulted from high $\mathrm{Na}$ concentrations.

The mechanistic model based on data in Appendix E under-predicted sorption significantly (factor of 6.25 difference). However, the general trends across the $\mathrm{pH}$ range matched quite well (Figure 8). Sorption was predicted to be largely controlled by the high-affinity sites of illite (Figure 9) followed by sorption to clinoptilolite and smectite. The predictions suggests that either the number of illite high-affinity sites or the affinity of Cs for illite high-affinity sites in our model is too low. Other ion exchange sites or ion exchange minerals have less influence on the final aqueous cesium concentration in solution under these conditions.

As in the case of strontium, there are many parameters that can be adjusted to improve the model fit to the data. However, adjusting parameters in our mechanistic model without justification from published or additional sorption data is not scientifically defensible. We limit the proposed changes to our mechanistic model to scientifically defensible ones.

\footnotetext{
${ }^{13}$ One might expect that a reduction of smectite CEC by $50 \%$ would have a large effect on Sr sorption. However, under certain conditions, it may not affect sorption significantly. At low pH (high aqueous calcium), Sr sorption is extremely weak; thus, the reduction in CEC does not significantly affect the predicted aqueous $\mathrm{Sr}$ concentration. However, when sorption is strong (high $\mathrm{pH}$, low calcium), one expects aqueous $\mathrm{Sr}$ to increase by $50 \%$ when the $\mathrm{CEC}$ is reduced by $50 \%$; this is observed in the $\mathrm{pH} \sim 9.5$ samples.
} 
A cursory examination of published ion exchange data not used in building our mechanistic model suggest that some ion exchange reaction constants in our mechanistic model may, in fact, result in under-predicted sorption. First, the reaction constant used for $\mathrm{Cs}-\mathrm{Na}$ exchange on smectite ( $\log \mathrm{K}=0.79$ ) was based on the standard free energies reported in Table 5 of Gast (1972) for Wyoming bentonite. However, reaction constants determined in Gast (1972) for two smectites over a range of cesium concentrations revealed that the cesium affinity for smectite is non-linear (see Table 3 of Gast (1972)). This suggests that multiple sites exist on smectite each of which has a different affinity for cesium (and other cations as well). In our batch experiments, the maximum cesium load on the surface was $0.01 \%$ of total ion exchange sites. In Gast (1972), at an ion exchange site load of $3 \%$, Log K reaction constants for two different smectite minerals were 1.2 and 1.6. The predicted sorption behavior of cesium using a Cs-Na exchange constant of $\log \mathrm{K}=1.6$ instead of 0.79 is shown in Figure 8. The increase in cesium affinity for smectite does not greatly affect the sorption behavior of cesium on U-1a alluvium under these batch sorption conditions because illite plays the dominant sorption role. However, it improves the trend in the data as a function of $\mathrm{pH}$ by reducing the aqueous cesium concentration at high $\mathrm{pH}$.

The dominant mechanism controlling cesium sorption in these batch experiments is cesium sorption to the high-affinity sites of illite. The value used in our mechanistic model ( $\log \mathrm{K}=5.6)$ was based on the Cs-Na exchange constant listed in Table 1 of Brouwer et al. (1983) and reproduced here as Table 8. However, the data in Table 1 of Brouwer et al. (1983) are not self-consistent. If we calculate Cs-Na exchange from the combination of $\mathrm{Cs}^{+}-\mathrm{M}^{2+}, \mathrm{Rb}^{+}-\mathrm{M}^{2+}$, and $\mathrm{Rb}^{+}-\mathrm{Na}^{+}$, an exchange constant of $\mathrm{Log} \mathrm{K}=6.8$ results. This value is significantly greater and indicates that a significant level of data uncertainty exists. The predicted aqueous cesium concentration matches measured data quite well when the exchange constant for cesium is adjusted to $\log K=6.7$ (Figure 8). An additional improvement to the data fit could be made by adjusting the divalent cation affinity to high-affinity illite sites. Although this adjustment cannot be justified directly based on the data of Brouwer et al. (1983), the uncertainty in the divalent cation reaction constant is likely to be similar to that of Cs, described above, and the adjustment to the reaction constant is rather small. The reaction constant adjustments are listed in Figure 8 and Table 9.

\subsubsection{Sorption of $0.1 \mathrm{mg} / \mathrm{L}$ europium on $\mathrm{U}-1$ a alluvium}

Figure 10 presents the $0.1 \mathrm{mg} / \mathrm{L}$ europium batch sorption data and two model predictions. Because europium concentrations in the U-1a alluvium were extremely low prior to adding the europium spike (Table 3), it was not necessary to account for background europium in model predictions. After addition of the europium spike to blanks, $\sim 10 \%$ of europium was lost either due to precipitation or to sorption to container walls. This is not surprising given the typically strong sorption behavior of the trivalent rare earth elements.

The initial europium concentration in spiked samples was $\sim 7 \times 10^{-7} \mathrm{~mol} / \mathrm{L}$ and dropped by more than three orders of magnitude after reaction with U-1a alluvium. The $K_{d}$ s ranged from 11000 to $96000 \mathrm{~mL} / \mathrm{g}$ over the $\mathrm{pH}$ range examined here. Sorption was affected by 
the solution composition but, unlike cesium and strontium, sorption was controlled in large part by sorption to calcite (Figure 11). At low $\mathrm{pH}$, sorption was reduced due to competition with $\mathrm{Ca}$ for calcite surface sites. At high $\mathrm{pH}$, the reduction in sorption resulted from the formation of $\mathrm{Eu}\left(\mathrm{CO}_{3}\right)_{2}{ }^{-}$anion complexes in solution.

Two model predictions are presented in Figure 10, both of which capture the sorptive capacity of U-1a alluvium for europium to a large extent. The two model predictions differ in the way that carbonate alkalinity is assigned to each sorption sample. ${ }^{14}$ For cesium and strontium, the effect of carbonate alkalinity is minor because carbonate complexation with cesium, strontium, or the major solution cations is relatively weak. For europium, complexation to carbonate in solution may significantly affect sorption because the formation of $\mathrm{Eu}\left(\mathrm{CO}_{3}\right)_{2}{ }^{-}$anions reduces the affinity of europium for the calcite surface. In the first prediction, carbonate alkalinity was assigned based on calcite equilibrium and the measured $\mathrm{Ca}$ concentration in solution. In the second prediction, carbonate alkalinity was assigned based on an equilibrium state with atmospheric $\mathrm{CO}_{2}(\mathrm{~g})$ but allowing the solution to be under- or over-saturated with respect to calcite. In general, the second method resulted in significantly higher carbonate concentrations in solution at high $\mathrm{pH}$, was consistent with a charge-balanced solution, and predicted sorption more effectively (Figure 11). This suggests that calcite remained somewhat supersaturated at relatively high $\mathrm{pH}$ during the $\sim 14$ days of the batch sorption experiments. The outlying data point at $\mathrm{pH} 9.2$ results from an anomalously low measured $\mathrm{Ca}$ concentration in solution. Since Ca competes with europium for surface sites on calcite, the low measured Ca concentration results in an anomalously low aqueous europium prediction. Regardless, our mechanistic model predictions are in good agreement with measured sorption data across the entire $\mathrm{pH}$ range examined.

\subsubsection{Sorption of $0.1 \mathrm{mg} / \mathrm{L}$ samarium on $U-1$ a alluvium}

Figure 12 presents the $0.1 \mathrm{mg} / \mathrm{L}$ samarium batch sorption data and four model predictions. Because samarium concentrations in the U-1a alluvium were extremely low prior to adding the samarium spike (Table 3), it was not necessary to account for background samarium in model predictions. After addition of the samarium spike to blanks, up to $25 \%$ of samarium was lost either to precipitation or sorption to container walls. This is somewhat greater than in the europium case but, again, not surprising. The loss of samarium to container walls was not accounted for in our model.

The behavior of samarium was nearly identical to that of europium in sorption samples. Rare earth elements are known to behave similarly (Koeppenkastrop and Decarlo, 1992; Lee and Byrne, 1993; Terakado and Masuda, 1988; Zhong and Mucci, 1995). The samarium $K_{d}$ s ranged from 14000 to $104000 \mathrm{~mL} / \mathrm{g}$ over the $\mathrm{pH}$ range examined here, similar to europium.

Four model predictions are presented in Figure 12. Two of the model predictions were calculated identically to the europium modeling case (Section 3.1.4). However, unlike

14 Carbonate alkalinity was not determined for these batch samples but great effort was made to ensure that each sample was at equilibrium with calcite and atmospheric $\mathrm{CO}_{2}(\mathrm{~g})$. 
europium, samarium sorption was significantly over-predicted (primarily via calcite, as in the case of europium), particularly at the higher $\mathrm{pHs}$. This is unexpected since samarium and europium sorption should be nearly equivalent (as typically observed from experimental sorption data, see Koeppenkastrop and Decarlo, 1992; Zhong and Mucci, 1993). An examination of our mechanistic database reveals that, although the aqueous speciation data for these two rare earth elements are quite similar, $\log \mathrm{K}=4.62$ for samarium sorption to calcite while for europium, it is 4.14. Two possibilities are available to reconcile this issue. First, if we assume that the sorption reaction constant for samarium on calcite is too high and we adjust it to match europium, we can arrive at a good fit to the sorption data (Figure 12). Second, if we assume that the europium sorption constant to calcite is too low, adjust it to match samarium, and lower the reactive surface area of calcite, we can also achieve a good match for both predicted europium and samarium. While the first option is simpler, we will show in the flow-through experiments that the second option results in greater consistency with all data presented in this report.

\subsubsection{Summary of batch sorption experiments}

The interaction of strontium, cesium, europium and samarium with U-1a alluvium over a range of $\mathrm{pH}$ from 7.5 to 9.5 was predicted quite well using the mechanistic surface complexation/ion exchange approach. This result provides significant validation to our mechanistic near-field HST model. However, some adjustments to our database could improve the model fit to the measured sorption data. First, the results suggest that either the strontium affinity for smectite or the cation exchange capacity of smectite is too high. A reduction of cation exchange capacity by $50 \%$ significantly improves the data fit. Second, the affinities of cesium for smectite and high-affinity sites of illite are too low. This results in a factor of $\sim 6$ over-prediction of aqueous cesium concentrations by our model. Based on published information, we suggest an increase in the Log $\mathrm{K}$ for these reactions (see Table 9). Finally, while the prediction of Eu and Sm sorption to U-1a alluvium is quite good, the over-prediction of $\mathrm{Sm}$ but not Eu sorption reveals some inconsistencies in our mechanistic database. Based on these results and those from flowthrough experiments discussed in the following section, we suggest that Log $\mathrm{K}$ of Eu on calcite is low and the reactive surface area of calcite is high. This is discussed further in the following section.

\subsection{Flow-through experiments}

In the following section, we present results from four flow-through experiments performed using either U-1a alluvium or UE-5n alluvium. The results are compared to two sets of model predictions based on our mechanistic sorption approach. Initially, model predictions are based on the original database parameters listed in Appendix E; parameter changes discussed in the previous section are not included in these model predictions. In cases where model fits to flow-through data are inadequate, some parameter adjustments are suggested and the resulting model predictions are presented. When appropriate, the adjusted parameters are discussed in the context of batch sorption data presented in Section 3.1. The flow-through data, combined with batch experiment 
data, are used to validate our mechanistic approach and provide model improvement recommendations.

\subsubsection{Experiment \#1: Iodide, cesium, strontium, samarium, and uranium transport through $U-1$ a alluvium}

Figures 13 to 15 present the breakthrough data for iodide, cesium, strontium, samarium, and uranium transport through U-1a alluvium (see Tables 4 to 6 and Appendix A for details). However, only iodide, strontium, and uranium breakthrough was observed in any significant quantity. Along with the experimental data are two predicted breakthrough curves calculated using our mechanistic sorption approach and CRUNCH reactive transport code. In the first simulation, sorption was simulated using the data compiled in Appendix E. In the second case, some adjustments to the reactive surface areas, cation exchange capacities, and reaction constants were made to improve the model fit to the data. These changes are listed in Table 9 and are consistent with suggested parameter changes based on batch sorption experiments.

As described in Section 2 of this report, this flow-through experiment entailed initial equilibration of the alluvium column followed by injection of a long pulse of solution containing sorbing elements and a tracer (Table 6), followed, in turn, by continued flow of uncontaminated synthetic Frenchman Flat alluvium water. The outline of the pulse can be most easily observed from iodide breakthrough data; iodide (a tracer) breakthrough data are characterized by a square pulse that begins at $\sim 1$ pore volume (Figure 14) and ends at $\sim 67$ pore volumes (Figure 15). The tailing in the iodide breakthrough profile results from a combination of dispersion and possible diffusioncontrolled access to a small fraction of the column fluid. The data density in Experiment \#2 (Section 3.2.2) is much greater in the iodide breakthrough region of the experiment; discussion of iodide dispersion and pore-water accessibility is, therefore, reserved for the following section.

The constant breakthrough of strontium at $\mathrm{C} / \mathrm{Co}=0.04$ at early times results from the release of background strontium from U-1a alluvium ion exchange sites; it is not related to the pulse of strontium introduced into the column. This background concentration is consistent with the measured strontium concentration in water at equilibrium with $\mathrm{U}-1 \mathrm{a}$ alluvium $\left(1.92 \times 10^{-6} \mathrm{~mol} / \mathrm{L}\right.$, Table 2$)$ divided by the strontium Co of Experiment \#1 $\left(7.13 \times 10^{-5} \mathrm{~mol} / \mathrm{L}\right.$, Table 6$)$.

The uranium breakthrough profile is similar to that of the non-sorbing tracer (iodide). However, uranium breakthrough is a factor of $\sim 3$ slower than iodide (i.e., retardation factor approximately 3$){ }^{15}$ Strontium retardation is significantly greater than uranium

\footnotetext{
${ }^{15}$ The retardation factor is calculated from the ratio of travel times of a radionuclide to that of the tracer. When the $\mathrm{x}$-axis units are pore volumes, the retardation factor can be calculated directly from the pore volumes at $\mathrm{C} / \mathrm{Cmax}=0.5$ for each radionuclide. For example, in Figure $14, \mathrm{C} / \mathrm{Cmax}=0.5$ for $\mathrm{U}$ at $\sim 3$ pore volumes. The retardation factor for $U$ is, therefore, $\sim 3$. The same calculation can be made at the end of the radionuclide pulse (Figure 15). Tracer $\mathrm{C} / \mathrm{Cmax}$ is at $\sim 67$ while $\mathrm{U} \mathrm{C} / \mathrm{Cmax}$ is at $\sim 70$. The net retardation factor for $\mathrm{U}$ is, therefore, $\sim 3$.
} 
while significant quantities of cesium and samarium are never observed in the downstream solution. ${ }^{16}$ The retardation factor for cesium and samarium must be greater than 275 (the total number of pore volumes that passed through the column).

The breakthrough of both iodide and uranium is predicted quite well using our mechanistic approach based on sorption constants and mineral reactivities tabulated in Appendix E. ${ }^{17}$ However, the tailing of uranium in Figure 15 could not be matched. The difference between measured data and model prediction may result from either desorption kinetics or fluid accessibility. Slow desorption kinetics can produce tailing in flow through experiments. However, if some pore space in the column is accessible only via diffusion, tailing may also result. These flow-through experiments were modeled assuming plug-flow and equilibrium sorption; the tailing effects could, therefore, not be simulated. Additional flow-through experiments in which the flow rate is varied could be used to investigate tailing effects. However, it is important to remember that the tailing effects have only a secondary effect on transport when compared to the overall retardation behavior.

Simulated breakthrough results using our mechanistic approach based on data in Appendix E do not match well with measured cesium and strontium data (Figure 13). Strontium retardation is over-predicted while cesium retardation is under-predicted. This result is consistent with batch sorption experiments described in the previous section.

With some adjustment to the ion exchange constants and cation exchange capacities, a reasonable fit to measured cesium and strontium breakthrough can be accomplished. However, as stated in the discussion of batch sorption experiments, the number of parameters that can be adjusted is very large; adjustment of the mechanistic database is not justifiable without additional experimental data or available published data. We reserved ourselves to either (A) relatively small changes in reaction constants, cation exchange capacities, and mineral reactivities consistent with likely uncertainties in these values or (B) changes in reaction constants, cation exchange capacities, and mineral reactivities consistent with published information. Also, any parameter changes used to fit flow-through experiment data had to be in agreement with batch sorption experiment results as well.

For strontium, ion exchange to smectite appears to be the dominant mechanism controlling transport (Figure 16). This is consistent with batch sorption experiments. Batch sorption data indicate that the reactivity of smectite is less than predicted by our model. The difference in predicted and measured sorption can result from a difference in either cation exchange capacity or ion exchange reaction affinity. To fit the flow-through experiments, a relatively small change in both the cation exchange capacity of smectite and strontium ion exchange constant for smectite was effected. This resulted in a significant reduction in strontium sorption to smectite. However, smectite remained the

\footnotetext{
${ }^{16}$ A non-zero Cs value was reported for the first and last sample collected during the column experiments but the value was close to the detection limit. Samarium was never observed.

${ }^{17}$ In flow-through simulations, a dispersion of 0.01 meters was always used and based on model fits to tracer data from Experiment \#2. This is discussed in the following section.
} 
dominant sorber. The ion exchange constant for strontium on clinoptilolite was also changed. Ion exchange constants on clinoptilolite were made consistent with those recently reported in Pabalan (1994) and Pabalan and Bertetti (1999). The change in ion exchange constants on zeolite had only a minor effect on predicted flow-through results since smectite remained the dominant sorber. The changes made in the ion exchange constants are listed in Table 9. These changes resulted in a reasonable model fit to measured data (Figure 13) and could fit batch sorption data as well.

For the case of cesium, sorption was dominated by ion exchange to smectite and clinoptilolite (Figure 17). This is in contrast to batch sorption experiments in which sorption was dominated by ion exchange on illite high-affinity sites. The difference results from the significantly higher cesium concentration used in the flow-through experiments - high-affinity ion exchange sites on illite were saturated at the cesium concentration used here (Figure 18). Cesium sorption to smectite was increased to account for the non-linear sorption of cesium to smectite at low surface loads as in the case of batch sorption data (Section 3.1). Also cesium ion exchange on clinoptilolite was adjusted to be consistent with the ion exchange constants reported in Pabalan (1994) and Pabalan and Bertetti (1999). ${ }^{18}$ These changes resulted in little cesium breakthrough, consistent with the data.

Significant breakthrough of samarium or cesium did not occur over the duration of the experiment. However, SIMS was used to examine their migration within the flowthrough column by disecting the column at the end of the flow-through experiment $(\sim 275$ pore volumes). Data results are plotted in Figure 19. After adjustment of the reaction constants as described above, model fits to cesium data are good. Since strontium in U-1a alluvium measured by SIMS includes strontium related to ion exchange sites as well as that also found within the original rock-forming minerals, its migration based on SIMS is difficult to resolve. The match between predicted and measured strontium distribution is not, therefore, expected to be as good as in the cesium case. The measured cesium along the column length shows significant asymmetry in distribution: again, tailing may result from slow desorption kinetics/reversibility or diffusion-controlled access to some fraction of the fluid as discussed previously. The leading edge of the predicted cesium distribution most likely results from the significant numerical dispersion in the reactive transport code.

A reasonable agreement between the measured distribution and model predictions for samarium is possible only after adjusting the reactive surface area of calcite. This is consistent with batch experiment results described earlier. Calcite surface area was adjusted from $2.2 \mathrm{~m}^{2} / \mathrm{g}$ to $0.1 \mathrm{~m}^{2} / \mathrm{g}$ which results in an order-of-magnitude decrease in the sorptive capacity of the calcite in U-1a alluvium. The value of $2.2 \mathrm{~m}^{2} / \mathrm{g}$ was taken from Zachara et al. (1993) based on previous estimates of calcite surface areas ((Holford and Mattingly, 1975) and others). However, surface areas of calcite can vary widely, from

18 These authors did not report an ion exchange constant for Cs. However, the Cs ion exchange constant was adjusted so that the $\mathrm{Na} / \mathrm{Cs}$ ion exchange constant was equal to a linear combination of $\mathrm{K} / \mathrm{Cs}$ ion exchange reported in Ames (1964) and $\mathrm{Na} / \mathrm{K}$ ion exchange reported in Pabalan (1994). This had relatively little effect on the final results. 
micritic calcite with possibly tens of square meters per gram to large calcite single crystals with very small surface areas. A surface area of $0.1 \mathrm{~m}^{2} / \mathrm{g}$ is not unreasonable.

\subsubsection{Experiment \#2: Iodide, cesium, strontium, samarium, and neptunium transport through $U-1$ a alluvium}

Figures 20 to 22 present the breakthrough data and modeling results for iodide, cesium, strontium, samarium, and neptunium transport through U-1a alluvium (see Tables 4 to 6 and Appendix A for details). ${ }^{19}$ However, only iodide, neptunium and strontium break through in significant quantities. In this experiment, predicted breakthroughs were similar to Experiment \#1 for cesium and strontium but the measured breakthrough of both these ions was slightly faster. Inaccessibility of a fraction of the alluvium may have resulted from the slightly faster flow rates of this experiment. However, heterogeneity in alluvium distribution may also have increased dispersion. While the discrepancy in breakthrough of cesium and strontium in Experiment \#1 and \#2 cannot be fully explained, their breakthrough in these two flow-through experiments is in reasonable agreement. As in Experiment \#1, model results from Experiment \#2 were able to match experimental data only after some adjustment of model parameters (Figure 20).

Initial predictions of neptunium retardation were severely overestimated (Figure 20). Calcite was predicted to be the dominant neptunium sorber. However, consistent with the SIMS samarium results of Experiment \#1, these data suggest that the reactive surface area of calcite is significantly less than previously estimated. A reduction of calcite reactive surface area to $0.1 \mathrm{~m}^{2} / \mathrm{g}$ results in predicted breakthrough consistent with experimental results.

While the breakthrough of neptunium can be predicted approximately using an adjusted calcite surface area, the shape of the breakthrough does not match experimental data very well. Several factors may be affecting the breakthrough profile of neptunium. First, as previously mentioned, tailing may be the result of diffusion-limited access to some fraction of the alluvium. The tailing may also be related to slow desorption kinetics. Additionally, some neptunium may coprecipitate with calcite; this would account for the apparent mass-balance inequality between the predicted and experimental data which can be observed from the area under the experimental data versus the predicted curve. As will be shown in the UE-5n alluvium flow-through data, the shape of the predicted neptunium breakthrough curve matches the experimental data more closely when calcite comprises only a minor fraction of the alluvium mineralogy. This also suggests that calcite plays a dominant role in neptunium retardation in cases where calcite abundance is high.

Figures 21 and 22 present the breakthrough results for the iodide tracer in Experiment $\# 2$. In Figure 21, the predicted breakthrough curves from five simulations is shown to evaluate the level of dispersion in these flow-through experiments. The simulations vary

\footnotetext{
${ }^{19}$ As in the case of Experiment \#1, samarium was not observed at the downstream boundary at a significant concentration over the entire experiment. This column was not examined by SIMS; the migration of samarium could, therefore, not be evaluated.
} 
in the model (GIMRT or OS3D) and dispersivity used. The GIMRT code is computationally fast because it relies on the global implicit approach to solve the reactive transport problem. The benefit of the speed is offset by the detrimental effect of a large degree of numerical dispersion. The OS3D code relies on an operator splitting approach which limits numerical dispersion error at the cost of computational speed. When evaluating the dispersion effects in the column experiment using the OS3D code, a dispersion value of 0.01 meters seems appropriate. ${ }^{20}$ However, when this same dispersion is used in the GIMRT code, the dispersion effect is overestimated. In fact, when a dispersion of 0 meters is used in the GIMRT code, the hydrologic dispersion is still slightly overestimated. However, the effect of numerical dispersion is typically greater for tracers than for retarded species. We, therefore, use a dispersivity of 0.01 meters in all our model predictions. For convenience of speed, all predictions discussed in this report were made using the GIMRT code.

\subsubsection{Experiment \#3: Iodide, cesium, strontium, samarium, and uranium transport through $U E-5 n$ alluvium}

Figures 23 to 26 present the breakthrough data and modeling results for iodide, cesium, strontium, samarium, and uranium transport through UE-5n alluvium (see Tables 4 to 6 and Appendix A for details). However, only iodide and uranium breakthrough is observed in significant quantities. The U-1a alluvium radionuclide-sorbing mineral abundances follow the order smectite $>$ calcite $>$ biotite(illite) $>$ clinoptilolite $>$ hematite. In UE-5n alluvium, radionuclide-sorbing mineral abundances follow the order clinoptilolite $>$ smectite $>$ biotite (illite) $>$ calcite $>$ hematite (Table 1). The greater sorptive capacity of clinoptilolite for cesium and strontium relative to smectite would be expected to result in greater retardation of these elements. This effect can be observed from breakthrough data presented in Figure 23.

The non-zero iron oxide mineral abundance in the UE-5n alluvium should increase the retardation of uranium relative to $U-1$ a alluvium because iron oxide has a strong affinity for uranium. In fact, the predicted retardation factor for uranium increases from $\sim 3$ to $\sim 6{ }^{21}$ However, this increase in retardation is not observed in the measured data. To match measured data (see Figures 24 and 25), the reactive surface area of hematite must be reduced to $0.1 \mathrm{~m}^{2} / \mathrm{g}$. ${ }^{22}$ At this iron oxide surface area, predicted uranium sorption is no longer dominated by iron oxide. Instead, smectite becomes the dominant sorber. This suggests that iron oxide may not play a significant role in retarding uranium (and possibly other radionuclides as well) at UE-5n.

\footnotetext{
${ }^{20}$ Note, however, that asymmetry in the iodide breakthrough data cannot be fit exactly. This asymmetry lends additional support for the idea that a fraction of the column fluid may only be accessible by diffusion (e.g. dead-end pore effects).

${ }^{21}$ In our initial model prediction, an iron oxide surface area of $2.0 \mathrm{~m}^{2} / \mathrm{g}$ was used. In general, this is already a very low surface area for iron oxides. Fresh hydrous ferric oxide will typically have a surface area closer to $600 \mathrm{~m}^{2} / \mathrm{g}$ while goethite will have a surface area of $50 \mathrm{~m}^{2} / \mathrm{g}$ (Turner, 1995). $2.0 \mathrm{~m}^{2} / \mathrm{g}$ was used based on an earlier evaluation of published Frenchman Flat alluvium sorption data (Zavarin, 2001).

${ }^{22}$ Instead of reducing the surface area, we could have added a rate-limited sorption/desorption term to our model. Rate limited sorption/desorption might also improve the model fit to the tailing. However, we chose, at present, to keep the equilibrium modeling approach.
} 
The results presented in Figure 26 suggest that strontium may break through at trace levels. However, evaluating the breakthrough of strontium is complicated by the fact that background strontium concentrations in the alluvium are non-zero. This effect was more obvious in the U-1a alluvium but is still present in the UE-5n data. The observed breakthrough of trace strontium began when the flowing water in the column experiment was abruptly switched from the sorbing element and tracer-containing pulse to background synthetic Frenchman Flat water. This abrupt change in water chemistry may have induced a change in the background strontium concentration in the water at the downstream end of the column. The fact that the strontium concentration never increased above a trace level over the 350 pore volumes suggests that strontium breakthrough resulted from the background strontium in the alluvium and not the strontium pulse. To evaluate the breakthrough further, a SIMS analysis of the column would be required.

\subsubsection{Experiment \#4: Iodide, cesium, strontium, samarium, and neptunium transport through $U E-5 n$ alluvium}

Figure 27 presents breakthrough data for Experiment \#4; only iodide and neptunium breakthrough was observed in significant quantities during the experiment. As in the case of U-1a alluvium, neptunium retardation was over-predicted by our model. This, again, resulted from the over-prediction of the sorptive capacity of calcite (Figure 28). Even though the abundance of calcite in UE-5n alluvium is nearly an order of magnitude less than in U-1a alluvium, calcite is still predicted to dominate neptunium sorption. When the calcite surface area is adjusted to $0.1 \mathrm{~m}^{2} / \mathrm{g}$, the predicted retardation is more consistent with experimental data. However, the reactive surface area of iron oxide had to also be reduced to $0.1 \mathrm{~m}^{2} / \mathrm{g}$ to achieve a good fit between predicted and measured data (Figures 28 and 29). As in the case of uranium, these data indicate that iron oxide may contribute very little to the overall retardation of neptunium in UE-5n alluvium. It is important to note that the large difference in experimental breakthrough data for U-1a and UE-5n suggests that calcite will play a significant role in retarding neptunium when the calcite abundance is significant.

As in Experiment \#3, a trace concentration of strontium was observed in column effluent suggesting possible breakthrough of a small fraction of strontium (Figure 31). As in the previous experiment, observed strontium concentrations were only slightly above background and increased abruptly when the flowing solution was switched from the sorbing element- and tracer-containing solution to the background synthetic Frenchman

Flat solution. Again, it is likely that the strontium observed in the effluent is more likely background strontium than our spiked pulse strontium. A SIMS analysis of the column would be necessary to evaluate this effect.

\subsubsection{Summary of flow-through experiments}

The retardation behavior of cesium, strontium, samarium, neptunium, and uranium could not be accurately predicted without some adjustment of the sorption parameters listed in Appendix E. This is consistent with $\mathrm{U}-1$ a alluvium batch sorption modeling results in 
which strontium and samarium sorption was overpredicted and cesium sorption was underpredicted. However, with some reasonable adjustments to our model parameters consistent with the adjustments suggested in Section 3.1, a fit to the data was achieved. The required adjustments include the reduction in the affinity of strontium for smectite, an increase in cesium affinity for smectite and illite, and a reduction in the reactive surface area of iron oxide and calcite. The required parameter changes to achieve a reasonable fit to all data (batch and flow-through) are listed in Table 9. In general, the adjustments are justifiable by published experimental data or are within the limits of uncertainty of these parameters. The predicted transport results are, therefore, consistent with our experimental data only when the uncertainty in the mechanistic model parameters is appreciated. The uncertainty should be accounted for in transport model predictions. Additional laboratory data could certainly help reduce that uncertainty.

After adjustment of model parameters, the mechanistic surface complexation/ion exchange approach was able to predict the differences in retardation behavior of $\mathrm{U}-1 \mathrm{a}$ and UE-5n alluvium. Neptunium retardation was much greater in U-1a alluvium because calcite was much more abundant. Cesium and strontium were more retarded in $\mathrm{UE}-5 \mathrm{n}$ alluvium due to their strong affinity for clinoptilolite. Uranium retardation was very weak in both U-1a and UE-5n alluvium because it sorbs principally to iron oxides and neither alluvium contained significant quantities of these minerals. Furthermore, model predictions suggest that the reactive surface area of iron oxides in UE-5n alluvium are small and will, therefore, not contribute significantly to radionuclide retardation. Samarium sorbs strongly to a variety of minerals although it was predicted to sorb most strongly to calcite in U-1 a alluvium. Though the calcite reactive surface area was reduced from 2.2 to $0.1 \mathrm{~m}^{2} / \mathrm{g}$ to adequately fit the SIMS data, calcite still remained the dominant samarium sorber. A comparison to UE-5n alluvium could not be made due to the lack of SIMS data.

\section{Summary and Conclusions}

The laboratory batch and flow-through experiments presented in this report provide a basis for validating the mechanistic surface complexation and ion exchange model we use in our HST simulations. Batch sorption experiments were used to examine the effect of solution composition on sorption. Flow-through experiments provided for an analysis of the transport behavior of sorbing elements and tracers which includes dispersion and fluid accessibility effects. Analysis of downstream flow-through column fluids allowed for evaluation of weakly-sorbing element transport. SIMS analysis of the core after completion of the flow-through experiments permitted the evaluation of transport of strongly sorbing elements. A comparison between these data and model predictions provides additional constraints to our model and improves our confidence in near-field HST model parameters.

In general, cesium, strontium, samarium, europium, neptunium, and uranium behavior could be accurately predicted using our mechanistic approach but only after some adjustment was made to the model parameters. The required adjustments (Table 9) included a reduction in strontium affinity for smectite, an increase in cesium affinity for 
smectite and illite, a reduction in iron oxide and calcite reactive surface area, and a change in clinoptilolite reaction constants to reflect a more recently published set of data. In general, these adjustments are justifiable because they fall within a range consistent with our understanding of the parameter uncertainties. These modeling results suggest that the uncertainty in the sorption model parameters must be accounted for to validate the mechanistic approach. The uncertainties in predicting the sorptive behavior of $U-1 \mathrm{a}$ and UE-5n alluvium also suggest that these uncertainties must be propagated to nearfield HST and large-scale CAU models.

\section{Recommendations}

Based on our effort to validate the mechanistic approach to modeling radionuclide retardation in a porous flow environment, we make the following recommendations regarding the surface complexation/ion exchange model parameters defined in Appendix E and employed in recent radionuclide retardation calculations (Pawloski et al., 2000; Tompson et al., 1999; Tompson et al., 2001; Zavarin, 2001):

- The reactive surface area of calcite should be reduced from $2.2 \mathrm{~m}^{2} / \mathrm{g}$ to $0.1 \mathrm{~m}^{2} / \mathrm{g}$.

- The reactive surface area of iron oxide should be reduced from $2.0 \mathrm{~m}^{2} / \mathrm{g}$ to $0.1 \mathrm{~m}^{2} / \mathrm{g}$.

- The cation exchange capacity of smectite should be reduced from $0.85 \mathrm{meq} / \mathrm{g}$ to $0.425 \mathrm{meq} / \mathrm{g}$.

- The reaction constants for ion exchange on smectite should be adjusted to the values listed in Table 9.

- The reaction constants for ion exchange on high-affinity illite sites should be adjusted to the values listed in Table 9.

- The reaction constants for ion exchange on clinoptilolite should be adjusted to the more recently published data (Pabalan, 1994; Pabalan and Bertetti, 1999) listed in Table 9.

Finally, while the recommendations enumerated above significantly improve the fit of the mechanistic model to measured laboratory batch and flow-through experiments, significant uncertainty in these parameters still exists. For some parameters such as surface complexation reaction constants, uncertainty has been determined based on fits to a large number of sorption data sets (Tables E-3 and E-5). For other parameters (related to the characteristics of sorbing minerals) such as reactive surface areas, cation exchange capacities, and ion exchange constants, uncertainties exist but have not been quantified. Still other uncertainties related to the heterogeneous nature of fluid flow also exist. Radionuclide retardation predictions must, in all cases, address these uncertainties and their limitations. 


\section{References}

Ames, L.L., Jr., 1964. Some zeolite equilibria with alkali metal cations. American Mineralogist, 49: 127-145.

Bethke, C.M., 1996. Geochemical Reaction Modeling. Oxford University Press, New York, NY, 397 pp.

Brouwer, E., Baeyens, A.M. and Cremers, A., 1983. Cesium and rubidium ion equilibria in illite clays. J. Physical Chemistry, 87: 1213-1219.

Dzombak, D.A. and Morel, F.M.M., 1990. Surface complexation modeling : hydrous ferric oxide. Wiley, New York, xvii, 393 pp.

Fletcher, P. and Sposito, G., 1989. The chemical modeling of clay/electrolyte interactions for montmorillonite. Clay Minerals, 24: 375-391.

Gast, R.G., 1972. Alkali metal cation exchange on Chambers montmorillonite. Soil Science Society of America Proceedings, 36: 14-19.

Helgeson, H.C., 1969. Thermodynamics of hydrothermal systems at elevated temperatures and pressures. American J. Science, 267: 729-804.

Hinton, R.W., Harte, B. and Witt-Eichschen, G., 1995. Ion probe measurement on National Institute of Standards and Technology Standard Reference Material SRM 610 glass, trace elements. Analyst, 120: 1315-1319.

Holford, I.G.R. and Mattingly, G.E.G., 1975. Surface areas of calcium carbonates in soils. Geoderma, 13: 247-255.

Hsi, C.D. and Langmuir, D., 1985. Adsorption of uranyl onto ferric oxyhydroxides; application of the surface complexation site-binding model. Geochimica et Cosmochimica Acta, 49(9): 1931-1941.

IT_Corporation, 1999. Underground Test Area Project, Corrective Action Unit 98: Frenchman Flat. Volume 2: Groundwater Data Documentation Package. DOE/NV/13052-044, IT Corporation, Las Vegas, Nevada.

Johnson, J.W. and Lundeen, S.R., 1997. GEMBOCHS thermodynamic datafiles for use with the EQ3/6 modeling package, Lawrence Livermore National Laboratory, Livermore.

Keeney-Kennicutt, W.L. and Morse, J.W., 1984. The interaction of $\mathrm{Np}(\mathrm{V}) \mathrm{O}_{2}{ }^{+}$with common mineral surfaces in dilute aqueous solutions and seawater. Marine Chemistry, 15: 133-150.

Koeppenkastrop, D. and Decarlo, E.H., 1992. Sorption of Rare-Earth Elements From Seawater Onto Synthetic Mineral Particles - an Experimental Approach. Chemical Geology, 95(3-4): 251-263.

Lee, J.H. and Byrne, R.H., 1993. Complexation of trivalent rare earth elements (Ce, Eu, $\mathrm{Gd}, \mathrm{Tb}, \mathrm{Yb}$ ) by carbonate ions. Geochimica et Cosmochimica Acta, 57: 295-302.

McKinley, J.P., Zachara, J.M., Smith, S.C. and Turner, G.D., 1995. The influence of uranyl-hydrolysis and multiple site-binding reaction on adsorption of U(VI) to montmorillonite. Clays and Clay Minerals, 45(5): 586-598.

Pabalan, R.T., 1994. Thermodynamics of ion-exchange between clinoptilolite and aqueous solutions of $\mathrm{Na}^{+} / \mathrm{K}^{+}$and $\mathrm{Na}^{+} / \mathrm{Ca}^{2+}$. Geochimica et Cosmochimica Acta, 58: 4573-4590. 
Pabalan, R.T. and Bertetti, F.P., 1999. Experimental and modeling study of ion exchange between aqueous solutions and the zeolite mineral clinoptilolite. J. Solution Chemistry, 28(4): 367-393.

Pawloski, G.A., Tompson, A.F.B., Bruton, C.J. and Zavarin, M., Eds., 2000. Evaluation of the Hydrologic Source Term from Underground Nuclear Tests in Frenchman Flat and the Nevada Test Site (U). Contributors: W.L. Bourcier, C.J. Bruton, S.F. Carle, B.K. Esser, A.B. Kersting, R.M. Maxwell, G.A. Pawloski, J.A. Rard, D.E. Shumaker, D.K. Smith, A.F.B. Tompson, and M. Zavarin. UCRL-ID-138007, Lawrence Livermore National Laboratory, Livermore, California.

Pawloski, G.A., Tompson, A.F.B. and Carle, S.F., eds., 2001. Evaluation of the Hydrologic Source Term for Underground Nuclear Tests on Pahute Mesa and the Nevada Test Site: The Cheshire Test, Contributors: W.L. Bourcier, C.J. Bruton, S.F. Carle, J.I. Daniels, R.M. Maxwell, G.A. Pawloski, D.S. Shumaker, D.K. Smith, A.F.B. Tompson, and M. Zavarin. UCRL-ID-147023, Lawrence Livermore National Laboratory, Livermore, California.

Rose, T.P. 2001. Personal Communication: Groundwater composition at Frenchman Flat, Lawrence Livermore National Laboratory, Livermore, California, July, 2001.

Rose, T.P., Smith, D.K. and Werner, J.K., Jr., 1999. Lithologic, Mineralogic, and Petrographic Characterization of Alluvium for the U-1a.102C and 102D Drifts of the U-1a Tunnel Complex, Nevada Test Site. Report on work performed for the UGTA program, Lawrence Livermore National Laboratory, Livermore, California.

Shimizu, N., Semet, M.P. and Allegre, C.J., 1978. Geochemical applications of the quantitative ion-microprobe analysis. Geochimica et Cosmochimica Acta, 42: 1321-1334.

Steefel, C.I. and Yabusaki, S.B., 1995. OS3D/GIMRT, Software for modeling multicomponent-multidimensional reactive transport, User manual and programmer's guide. Pacific Northwest National Laboratory, Richland, WA.

Steefel, C.I., 2000. new directions in hydrogeochemical transport modeling: Incorporating multiple kinetic and equilibrium reaction pathways. In: L.R. Bentley, J.F. Sykes, C.A. Brebbia, W.G. Gray and G.F. Pinder (Editors), Computational Methods in Water Resources XIII. A.A. Balkema, Rotterdam, pp. 331-338.

Terakado, Y. and Masuda, A., 1988. The coprecipitation of rare-earth elements with calcite and aragonite. Chemical Geology, 69: 103-110.

Tompson, A.F.B., Bruton, C.J. and Pawloski, G.A., 1999. Evaluation of the hydrologic source term from the underground nuclear tests in Frenchman Flat and the Nevada Test Site: The CAMBRIC test. UCRL-ID-132300, Lawrence Livermore National Laboratory, Livermore.

Tompson, A.F.B., Zavarin, M., Bruton, C.J. and Pawloski, G.A., 2001. Simplified Hydrologic Source Term for Frenchman Flat Sensitivity Studies. Internal Report, Lawrence Livermore National Laboratory, Livermore, California.

Turner, D.R., 1995. A uniform approach to surface complexation modeling of radionuclide sorption. CNWRA 95-001, Center for Nuclear Waste Regulatory Analyses, San Antonio. 
Turner, G.D., Zachara, J.M., McKinley, J.P. and Smith, S.C., 1996. Surface charge properties and $\mathrm{UO}_{2}{ }^{2+}$ adsorption of a subsurface smectite. Geochimica et Cosmochimica Acta, 60(18): 3399-3414.

Viani, B.E. and Bruton, C.J., 1992. Modeling fluid-rock interaction at Yucca Mountain, Nevada: A progress report. UCRL-ID-109921, Lawrence Livermore National Laboratory, Livermore, CA.

Viani, B.E. and Bruton, C.J., 1996. Assessing the role of cation exchange in controlling groundwater chemistry during fluid mixing in fractured granite at Aspo, Sweden. UCRL-JC-121527, Lawrence Livermore National Laboratory, Livermore, CA.

Weaver, C.E. and Pollard, L.D., 1975. The Chemistry of Clay Minerals. Developments in Sedimentology 15. Elsevier, Amsterdam, 213 pp.

Zachara, J.M., Cowan, C.E. and Resch, C.T., 1993. Metal cation/anion adsorption on calcite carbonate. In: H.E. Allen, E.M. Perdue and D.S. Brown (Editors), Metals in groundwater. Lewis Publishers, Boca Raton, pp. 37-71.

Zavarin, M., 2001. Upscaling Radionuclide Retardation - Linking Mechanistic Surface Complexation and Ion Exchange Model to a Linear Kd Approach. Report on work performed for the UGTA program, Lawrence Livermore National Laboratory, Livermore, California.

Zavarin, M. and Bruton, C.J., 2000a. A Non-Electrostatic Surface Complexation Approach to Modeling Radionuclide Migration at the Nevada Test Site: Aluminosilicates. UCRL-ID-141840 DR, Lawrence Livermore National Laboratory, Livermore.

Zavarin, M. and Bruton, C.J., 2000b. A Non-Electrostatic Surface Complexation Approach to Modeling Radionuclide Migration at the Nevada Test Site: Iron Oxides and Calcite. UCRL-ID-141841 DR, Lawrence Livermore National Laboratory, Livermore.

Zhong, S.J. and Mucci, A., 1993. Calcite precipitation in seawater using a constant addition technique - a new overall reaction kinetic expression. Geochimica et Cosmochimica Acta, 57(7): 1409-1417.

Zhong, S.J. and Mucci, A., 1995. Partitioning of rare earth elements (REEs) between calcite and seawater solutions at 25-degrees-C and 1 atm, and high dissolved REE concentrations. Geochimica et Cosmochimica Acta, 59(3): 443-453.

Zinner, E. and Crozaz, G., 1986. A method for the quantitative measurement of rare earth element in the ion microprobe. Int. J. Mass Spec. Ion Proc., 69: 17-38.

\section{Acknowledgements}

This work was funded by the Underground Test Area Project, U.S. Department of Energy, National Nuclear Security Administration, Nevada Operations Office, and performed under the auspices of the U.S. Department of Energy by the University of California, Lawrence Livermore National Laboratory under Contract No. W-7405-Eng48. 
Table 1. Mineral abundances of U-1a and UE-5n alluvium used in batch and column flow-through experiments determined by quantitative XRD.

$$
\text { U-1a } \uparrow \quad \text { UE-5nt }
$$

Phase g/g, Normalized g/g, Normalized to to $100 \% \quad 100 \%$

\begin{tabular}{|c|c|c|}
\hline & to 100 & $100 \%$ \\
\hline & \multicolumn{2}{|c|}{ Radionuclide Sorbing Minerals $₫$} \\
\hline Biotite $\S$ & 3.4 & 3.3 \\
\hline Calcite & 18.2 & 2.6 \\
\hline Clinoptilolite & 1.3 & 19.7 \\
\hline Hematite & - & 0.3 \\
\hline \multirow[t]{2}{*}{ Smectite } & 30.0 & 11.6 \\
\hline & \multicolumn{2}{|c|}{--------- Inert Minerals $\Phi$---------- } \\
\hline Albite & - & 3.2 \\
\hline Bytownite & 9.3 & 30.0 \\
\hline Chlorite & 0.1 & - \\
\hline Cristobalite & - & 1.6 \\
\hline Dolomite & 0.5 & - \\
\hline Glass & 11.1 & 9.1 \\
\hline Hornblende & 0.4 & 0.6 \\
\hline Kaolinite & 4.0 & - \\
\hline Orthoclase & 3.2 & 7.4 \\
\hline Quartz & 17.5 & 8.3 \\
\hline Sanidine & 1.1 & 2.6 \\
\hline \multicolumn{3}{|c|}{$\dagger$ Referred to in Appendix B as U-1a.102C.V2. } \\
\hline \multicolumn{3}{|c|}{$\begin{array}{l}\$ \text { Based on a } 1: 1 \text { mix of UE- } 5 \text { n- } 1140 \text { ' and UE- } 5 n-1160 \text { ' samples } \\
\text { reported in Appendix B. }\end{array}$} \\
\hline \multicolumn{3}{|c|}{$\begin{array}{l}\S \text { Biotite includes illite and muscovite minerals as well in the XRD } \\
\text { analysis. }\end{array}$} \\
\hline \multicolumn{3}{|c|}{$\begin{array}{l}\text { I Radionuclide sorbing minerals and inert minerals defined based on } \\
\text { limitations of our mechanistic sorption model. }\end{array}$} \\
\hline
\end{tabular}


Table 2. Composition of solution in equilibrium with U-1a alluvium.

\begin{tabular}{lc}
\hline Sample & $\begin{array}{c}\text { Concentration, mol/L } \\
(\text { except } \mathrm{pH})\end{array}$ \\
\hline $\mathrm{pH}$ & 8.54 \\
$\mathrm{Cl}^{-}$ & $3.39 \times 10^{-4}$ \\
$\mathrm{NO}_{3}{ }^{-}$ & $1.61 \times 10^{-5}$ \\
$\mathrm{SO}_{4}{ }^{2-}$ & $9.37 \times 10^{-5}$ \\
$\mathrm{Na}^{+}$ & $1.01 \times 10^{-3}$ \\
$\mathrm{Mg}^{2+}$ & $2.47 \times 10^{-4}$ \\
$\mathrm{~K}^{+}$ & $1.70 \times 10^{-4}$ \\
$\mathrm{Ca}^{2+}$ & $3.57 \times 10^{-4}$ \\
$\mathrm{Sr}^{2+}$ & $1.92 \times 10^{-6}$ \\
$\mathrm{Cs}^{+}$ & $6.00 \times 10^{-10}$ \\
$\mathrm{Sm}^{3+}$ & - \\
$\mathrm{Eu}^{3+}$ & $3.40 \times 10^{-11}$ \\
$\mathrm{UO}_{2}{ }^{2+}$ & $3.00 \times 10^{-9}$ \\
\hline
\end{tabular}

Table 3. Initial element concentrations of calcite and $\mathrm{pH}$ equilibrated $\mathrm{U}-1 \mathrm{~A} 102 \mathrm{C}-\mathrm{V} 2$ alluvium.

\begin{tabular}{|c|c|c|c|c|c|c|c|c|}
\hline Sample pH & $\mathrm{Na}^{+}$ & $\mathrm{Mg}^{2+}$ & $\mathrm{K}^{+}$ & $\mathrm{Ca}^{2+}$ & $\mathrm{Sr}^{2+}$ & $\mathrm{Cs}^{+}$ & $\mathrm{Sm}^{3+}$ & $\mathrm{Eu}^{3+}$ \\
\hline 7.50 & $6.70 \mathrm{E}-4$ & $1.58 \mathrm{E}-3$ & $5.63 \mathrm{E}-4$ & $3.67 \mathrm{E}-2$ & $3.33 \mathrm{E}-5$ & $1.49 \mathrm{E}-9$ & $<4 \mathrm{E}-11$ & $4.34 \mathrm{E}-11$ \\
\hline 7.75 & $7.51 \mathrm{E}-4$ & $1.33 \mathrm{E}-3$ & $4.95 \mathrm{E}-4$ & $1.14 \mathrm{E}-2$ & $2.03 \mathrm{E}-5$ & $1.57 \mathrm{E}-9$ & $<4 \mathrm{E}-11$ & $2.17 \mathrm{E}-11$ \\
\hline 8.00 & $1.03 \mathrm{E}-3$ & $9.00 \mathrm{E}-4$ & $3.80 \mathrm{E}-4$ & $2.59 \mathrm{E}-3$ & $1.05 \mathrm{E}-5$ & $1.24 \mathrm{E}-9$ & $<4 \mathrm{E}-11$ & $<7 \mathrm{E}-12$ \\
\hline 8.25 & $1.37 \mathrm{E}-3$ & $5.38 \mathrm{E}-4$ & $3.66 \mathrm{E}-4$ & $8.51 \mathrm{E}-4$ & 4.65E-6 & $1.32 \mathrm{E}-9$ & $<4 \mathrm{E}-11$ & $<7 \mathrm{E}-12$ \\
\hline 8.50 & $2.20 \mathrm{E}-3$ & 2.92E-4 & $3.26 \mathrm{E}-4$ & $3.27 \mathrm{E}-4$ & $2.51 \mathrm{E}-6$ & $1.41 \mathrm{E}-9$ & $<4 \mathrm{E}-11$ & $<7 \mathrm{E}-12$ \\
\hline 8.75 & $3.92 \mathrm{E}-3$ & $1.35 \mathrm{E}-4$ & $3.32 \mathrm{E}-4$ & $1.33 \mathrm{E}-4$ & $1.38 \mathrm{E}-6$ & $1.32 \mathrm{E}-9$ & $<4 \mathrm{E}-11$ & $<7 \mathrm{E}-12$ \\
\hline 9.00 & $5.60 \mathrm{E}-3$ & 7.29E-5 & $2.22 \mathrm{E}-4$ & $6.40 \mathrm{E}-5$ & $7.53 \mathrm{E}-7$ & $1.24 \mathrm{E}-9$ & $<4 \mathrm{E}-11$ & $<7 \mathrm{E}-12$ \\
\hline 9.25 & $8.18 \mathrm{E}-3$ & $5.48 \mathrm{E}-5$ & $1.98 \mathrm{E}-4$ & $<1.37 \mathrm{E}-5$ & $5.02 \mathrm{E}-7$ & $1.24 \mathrm{E}-9$ & $<4 \mathrm{E}-11$ & $<7 \mathrm{E}-12$ \\
\hline 9.50 & $1.88 \mathrm{E}-2$ & $7.24 \mathrm{E}-5$ & $3.18 \mathrm{E}-4$ & $2.31 \mathrm{E}-5$ & $6.28 \mathrm{E}-7$ & $1.32 \mathrm{E}-9$ & $<4 \mathrm{E}-11$ & $<7 \mathrm{E}-12$ \\
\hline
\end{tabular}

* Uncertainty typically $<5 \%$ except when analyses approach detection limit. 
Table 4. Key parameters for U-1a and UE-5n alluvium flow-through experiments.

\begin{tabular}{|c|c|c|c|c|c|c|c|}
\hline & $\begin{array}{l}\text { Alluvium } \\
\text { Mass } \\
\text { (meas.) } \dagger \\
\mathrm{g}\end{array}$ & $\begin{array}{c}\text { Alluvium } \\
\text { Density } \\
\text { (meas.) } \\
\mathrm{g} / \mathrm{cm}^{3}\end{array}$ & $\begin{array}{c}\text { Column } \\
\text { Volume } \\
\text { (meas.) } \\
\mathrm{cm}^{3}\end{array}$ & $\begin{array}{c}\text { Porosity } \\
\text { (calc.) } \\
\%\end{array}$ & $\begin{array}{c}\text { Pore } \\
\text { Volume } \\
\text { (calc.) } \\
\text { mL }\end{array}$ & $\begin{array}{l}\text { Flow } \\
\text { Rate } \\
\text { (meas.) } \\
\mathrm{mL} / \mathrm{min}\end{array}$ & $\begin{array}{c}\text { Bulk } \\
\text { Density } \\
\text { (calc.) } \\
\mathrm{g} / \mathrm{cm}^{3}\end{array}$ \\
\hline & ------ & - & & U-1a & - & 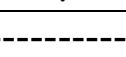 & ------ \\
\hline $\begin{array}{c}\text { Experiment } \\
\# 1\end{array}$ & 15.3 & 2.60 & 11.48 & 48.6 & 7.28 & 0.100 & 1.34 \\
\hline $\begin{array}{c}\text { Experiment } \\
\# 2\end{array}$ & 16.0 & 2.60 & 11.49 & 46.4 & 6.73 & 0.130 & 1.39 \\
\hline $\begin{array}{c}\text { Experiment } \\
\# 3\end{array}$ & 18.3 & 2.56 & 11.46 & $\begin{array}{c}\text { UE-5n } \\
37.8\end{array}$ & 5.73 & 0.120 & 1.59 \\
\hline $\begin{array}{c}\text { Experiment } \\
\# 4\end{array}$ & 15.3 & 2.56 & 11.48 & 47.9 & 6.90 & 0.126 & 1.33 \\
\hline
\end{tabular}

$\dagger$ We distinguish between measured (meas.) and calculated (calc.) values.

Table 5. Solution chemistry of synthetic Frenchman Flat water compared to average measured groundwater chemistry.

\begin{tabular}{lccc}
\hline & Flow-through & Rose, 2001 & IT, 1999 \\
\hline $\mathrm{pH}$ & 8.5 & $8.4 \pm 0.3 \dagger$ & $8.5 \pm 0.5$ \\
& $------------------~ \mathrm{mg} / \mathrm{kg}$ & --------------- \\
$\mathrm{F}^{-}$ & - & $1.1 \pm 0.3$ & - \\
$\mathrm{Na}^{+}$ & 83 & $79 \pm 26$ & $88 \pm 37$ \\
$\mathrm{~K}^{+}$ & 13 & $6.7 \pm 1.0$ & $8.3 \pm 2.1$ \\
$\mathrm{Mg}^{2+}$ & 2.8 & $2.8 \pm 1.7$ & $3.4 \pm 2.6$ \\
$\mathrm{Ca}^{2+}$ & 8.6 & $12.0 \pm 4.7$ & $11.2 \pm 7.9$ \\
$\mathrm{Sr}^{2+}$ & - & - & $0.5 \pm 1.1$ \\
$\mathrm{Cl}^{-}$ & 15 & $13.2 \pm 3.5$ & $20 \pm 20$ \\
$\mathrm{HCO}_{3}{ }^{-}$ & 186 & $190 \pm 62$ & $193 \pm 84$ \\
$\mathrm{SO}_{4}{ }^{2-}$ & 35 & $34.8 \pm 8.7$ & $46 \pm 38$ \\
$\mathrm{SiO}_{2}$ & 27 & & $56 \pm 21$ \\
\hline+
\end{tabular}

$\dagger$ Uncertainty $( \pm 1 \mathrm{SD})$ determined from analyses of a number of groundwater samples.

Table 6. Initial sorbing element and tracer concentrations in spiked groundwater solutions of flow-through experiments.

\begin{tabular}{|c|c|c|c|c|c|c|}
\hline & $\mathrm{U}$ & $\mathrm{Sm}$ & Cs & $\mathrm{Sr}$ & $\mathrm{Np}$ & $\mathrm{I}$ \\
\hline & \multicolumn{6}{|c|}{------------------------------------- mol/L ---------------------------------- } \\
\hline Experiment \#1 & $3.28 \mathrm{E}-6$ & $1.34 \mathrm{E}-6$ & $1.01 \mathrm{E}-4$ & $7.13 \mathrm{E}-5$ & & $6.68 \mathrm{E}-5$ \\
\hline Experiment \#2 & & $6.62 \mathrm{E}-7$ & $1.05 \mathrm{E}-4$ & $6.62 \mathrm{E}-5$ & $5.17 \mathrm{E}-6$ & $9.76 \mathrm{E}-5$ \\
\hline Experiment \#3 & $3.37 \mathrm{E}-6$ & $2.50 \mathrm{E}-6$ & $9.86 \mathrm{E}-5$ & $6.99 \mathrm{E}-6$ & & $9.76 \mathrm{E}-5$ \\
\hline Experiment \#4 & & $3.09 \mathrm{E}-7$ & $8.37 \mathrm{E}-5$ & $5.52 \mathrm{E}-5$ & 4.18E-6 & $5.63 \mathrm{E}-5$ \\
\hline
\end{tabular}


Table 7. Establishment of average $\mathrm{SiO}_{2}$ concentration in $\mathrm{U}-1 \mathrm{a}$ alluvium for SIMS analysis.

\begin{tabular}{lccc}
\hline Mineral & $\begin{array}{c}\text { Normalized } \\
\text { Abundance }\end{array}$ & $\begin{array}{c}\text { Wt. \% } \mathrm{SiO}_{2} \\
\text { in Mineral }\end{array}$ & $\begin{array}{c}\text { Wt. \% } \mathrm{SiO}_{2} \\
\text { X Abundance }\end{array}$ \\
\hline Smectite & 0.375 & $51 \dagger$ & 19.13 \\
Quartz & 0.250 & 100 & 25.00 \\
Volcanic glass & 0.125 & $72.5 \dagger$ & 9.06 \\
Calcite & 0.250 & 0 & 0.00 \\
\hline
\end{tabular}

$\dagger$ avg. of 17 smectite analyses (Weaver and Pollard, 1975)

$\$$ avg. of 22 analyses of volcanic glass in ER-5-4 alluvium (LLNL, unpublished data)

Table 8. Log $\mathrm{K}$ values and cation exchange capacities reproduced from Table 1 of Brouwer et al. (1983).

\begin{tabular}{lcccccc}
\hline Ion & & Log K & \multicolumn{3}{c}{ Fraction of total CEC $\dagger$} \\
Exchange & Site I & Site II & Site III & Site I & Site II & Site III \\
\hline $\mathrm{Cs}^{+}-\mathrm{M}^{2+}+$ & $12.9-13.3$ & 6.0 & 2.0 & 0.005 & 0.03 & 0.965 \\
$\mathrm{Rb}^{+}-\mathrm{M}^{2+}$ & 10.8 & 6.0 & 2.0 & 0.005 & 0.03 & 0.965 \\
$\mathrm{Cs}^{+}-\mathrm{Na}^{+}$ & 5.6 & 3.0 & 1.6 & 0.005 & 0.025 & 0.97 \\
$\mathrm{Rb}^{+}-\mathrm{Na}^{+}$ & 4.5 & 3.0 & 1.2 & 0.005 & 0.025 & 0.97 \\
$\mathrm{Cs}^{+}-\mathrm{K}^{+}$ & 4.1 & 1.4 & 0.7 & 0.0025 & 0.025 & 0.9725 \\
\hline
\end{tabular}

$\dagger$ total CEC is $0.2 \mathrm{meq} / \mathrm{g}$

$\$ \mathrm{M}^{2+}$ refers to $\mathrm{Ca}, \mathrm{Sr}$, and $\mathrm{Ba}$ divalent cations

Table 9. List of parameters adjusted to fit batch and flow-through experimental data.

\begin{tabular}{|c|c|c|c|}
\hline Parameter & Old value & New value & Units \\
\hline \multicolumn{4}{|c|}{ SMECTITE } \\
\hline $2 \mathrm{Na}^{+}-->\mathrm{Ca}^{2+}, \mathrm{Mg}^{2+} \mathrm{Sr}^{2+}$ & 0.17 & 0.0 & $\log K$ \\
\hline $2 \mathrm{Na}^{+}-->\mathrm{Sr}^{2+}$ & 0.17 & -0.4 & $\log K$ \\
\hline $\mathrm{Na}^{+}-->\mathrm{Cs}^{+}$ & 0.792 & 1.75 & $\log K$ \\
\hline Cation Exchange Capacity & 0.85 & 0.425 & $\mathrm{meq} / \mathrm{g}$ \\
\hline \multicolumn{4}{|c|}{ ILLITE/MICA, Site I } \\
\hline $2 \mathrm{Na}^{+}-->\mathrm{Ca}^{2+}, \mathrm{Mg}^{2+}, \mathrm{Sr}^{2+}$ & -2.05 & -0.75 & $\log K$ \\
\hline $\mathrm{Na}^{+}-->\mathrm{Cs}^{+}$ & 5.718 & 6.718 & $\log K$ \\
\hline \multicolumn{4}{|c|}{ CLINOPTILOLITE } \\
\hline $\mathrm{Na}^{+}-->\mathrm{K}^{+}$ & 1.10 & 1.40 & $\log K$ \\
\hline $\mathrm{Na}^{+}-->\mathrm{Cs}^{+}$ & 1.71 & 2.01 & $\log K$ \\
\hline $2 \mathrm{Na}^{+}-->\mathrm{Ca}^{2+}$ & -0.074 & 0.72 & $\log K$ \\
\hline $2 \mathrm{Na}^{+}-->\mathrm{Sr}^{2+}$ & 0.074 & 0.50 & $\log K$ \\
\hline \multicolumn{4}{|c|}{ CALCITE } \\
\hline Surface area & 2.2 & 0.1 & $\mathrm{~m}^{2} / \mathrm{g}$ \\
\hline \multicolumn{4}{|c|}{ IRON OXIDE } \\
\hline Surface area & 2.0 & 0.1 & $\mathrm{~m}^{2} / \mathrm{g}$ \\
\hline
\end{tabular}




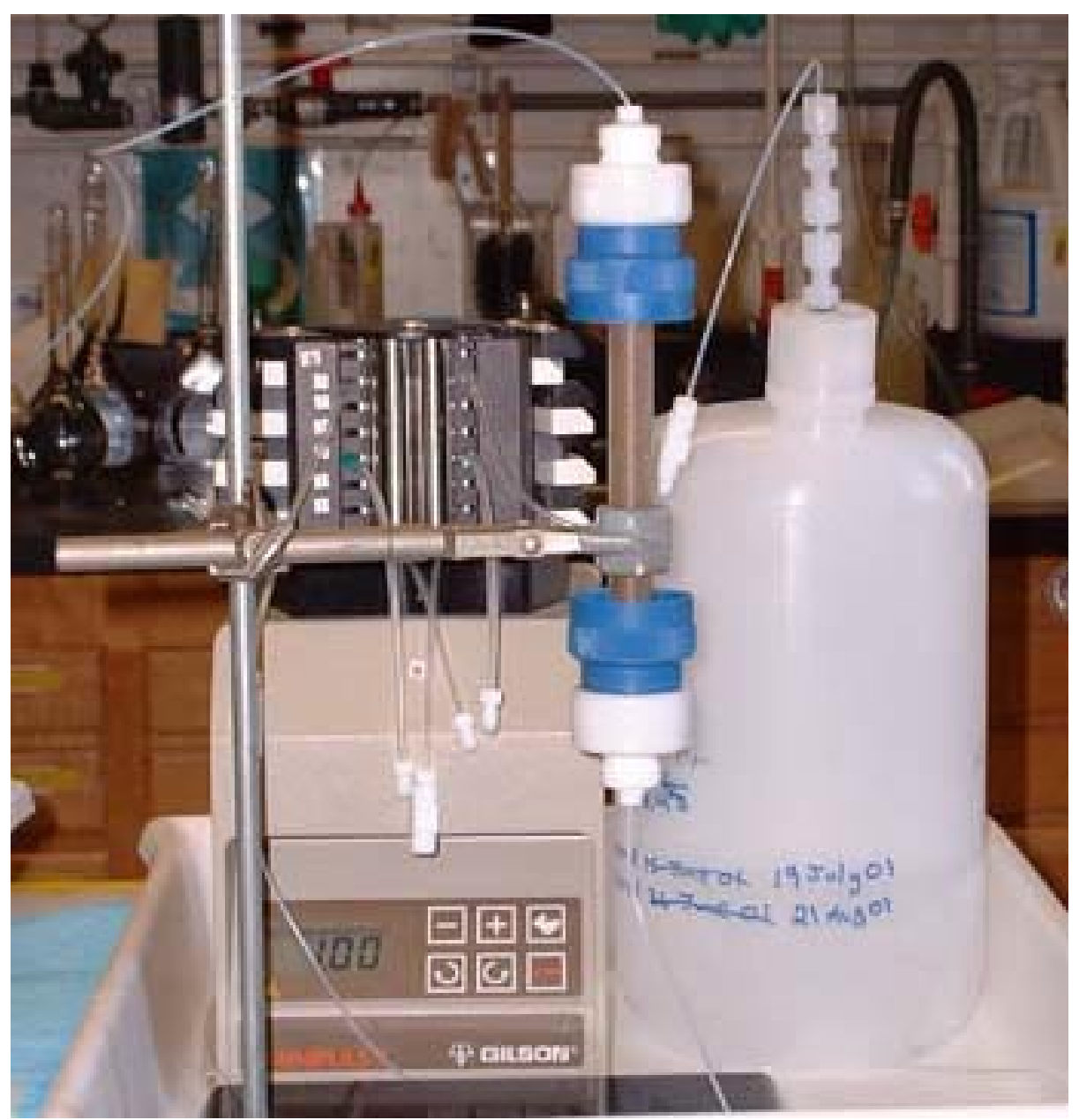

Figure 1. Photograph of column flow-through experiment system.

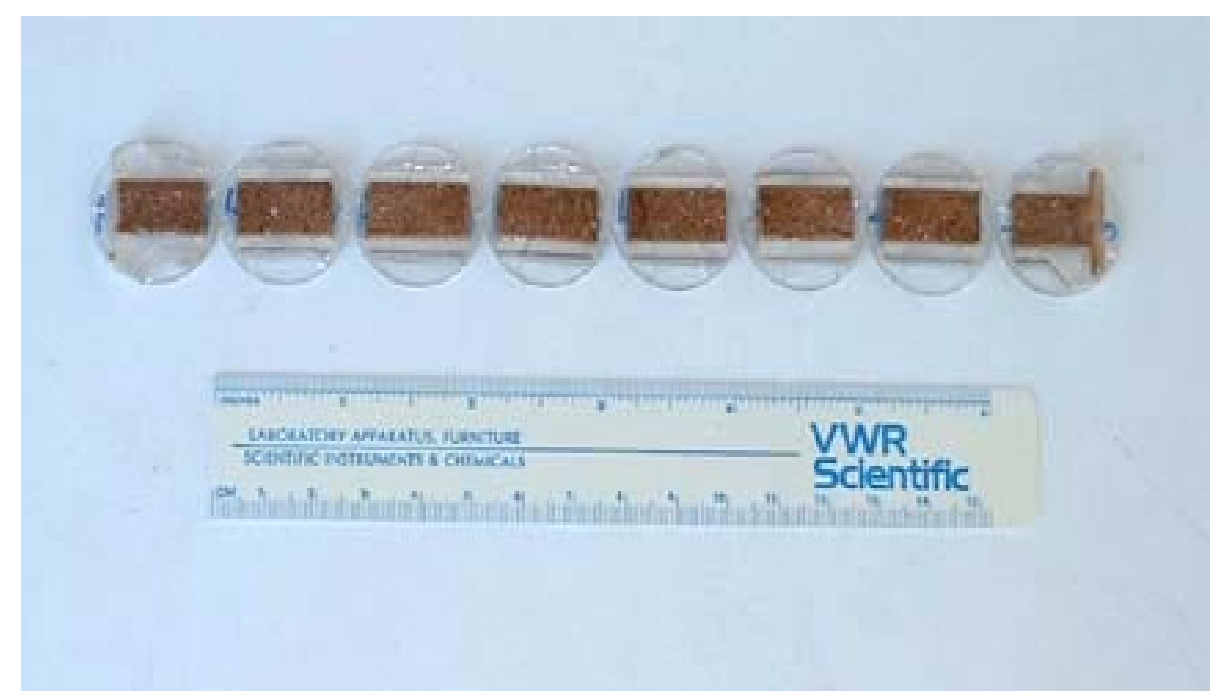

Figure 2. Photograph of SIMS sample mounts prepared from epoxy impregnated flow-through column Experiment \#2. 


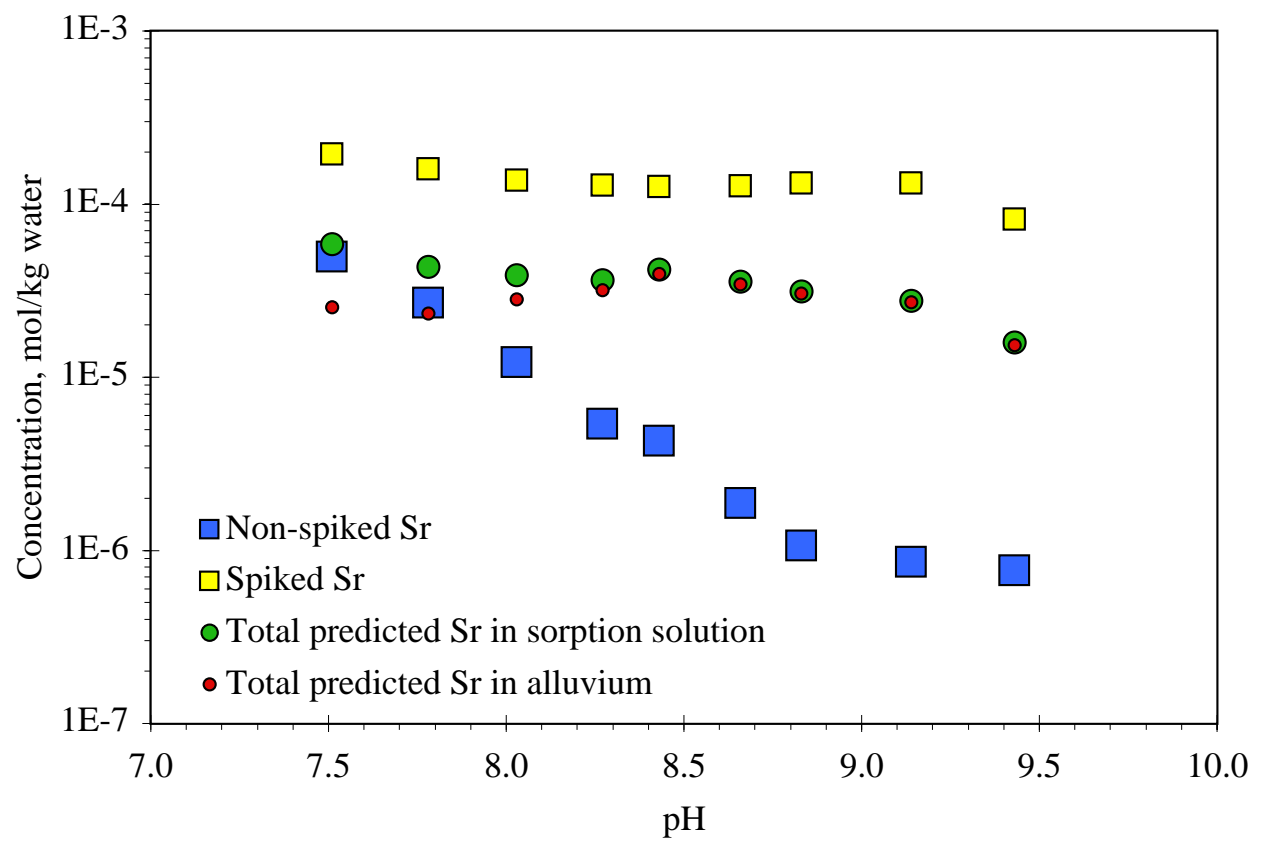

Figure 3. Measured and predicted concentrations of strontium in the $10 \mathrm{mg} / \mathrm{L}$ strontium $\mathrm{U}-1 \mathrm{a}$ alluvium sorption blanks. Aqueous + sorbed strontium in the non-spiked blanks was determined by predicting sorbed strontium from the measured non-spiked aqueous concentrations. Initial $\mathrm{Sr}$ refers to strontium in the initial solutions (Table 3 ).

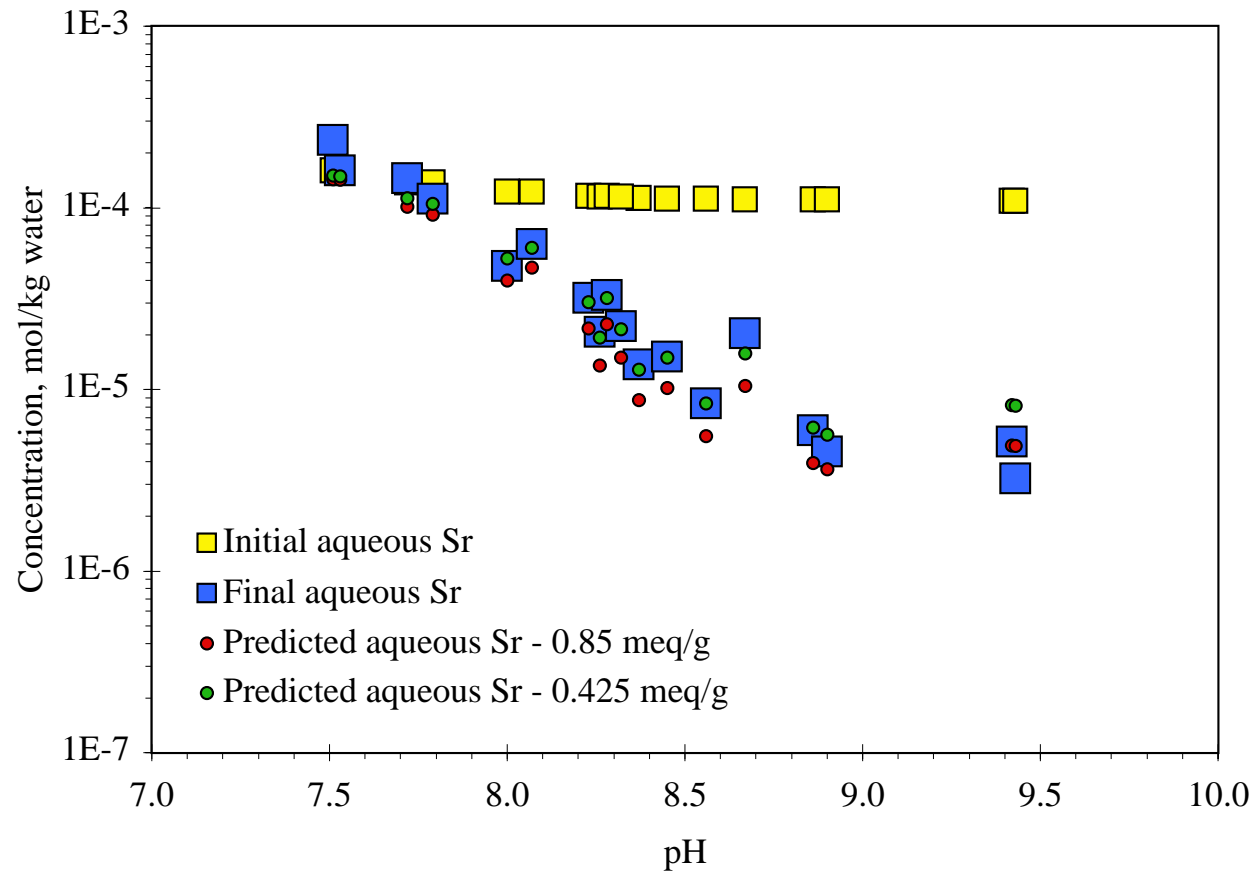

Figure 4. Measured and predicted concentrations of strontium in the $10 \mathrm{mg} / \mathrm{L}$ strontium $\mathrm{U}-1$ a alluvium sorption samples. Initial spiked strontium determined from non-spiked strontium in blanks + spike strontium. Predicted aqueous strontium calculated using $0.85 \mathrm{meq} / \mathrm{g}$ (red) and $0.425 \mathrm{meq} / \mathrm{g}$ (green) smectite cation exchange capacities. 


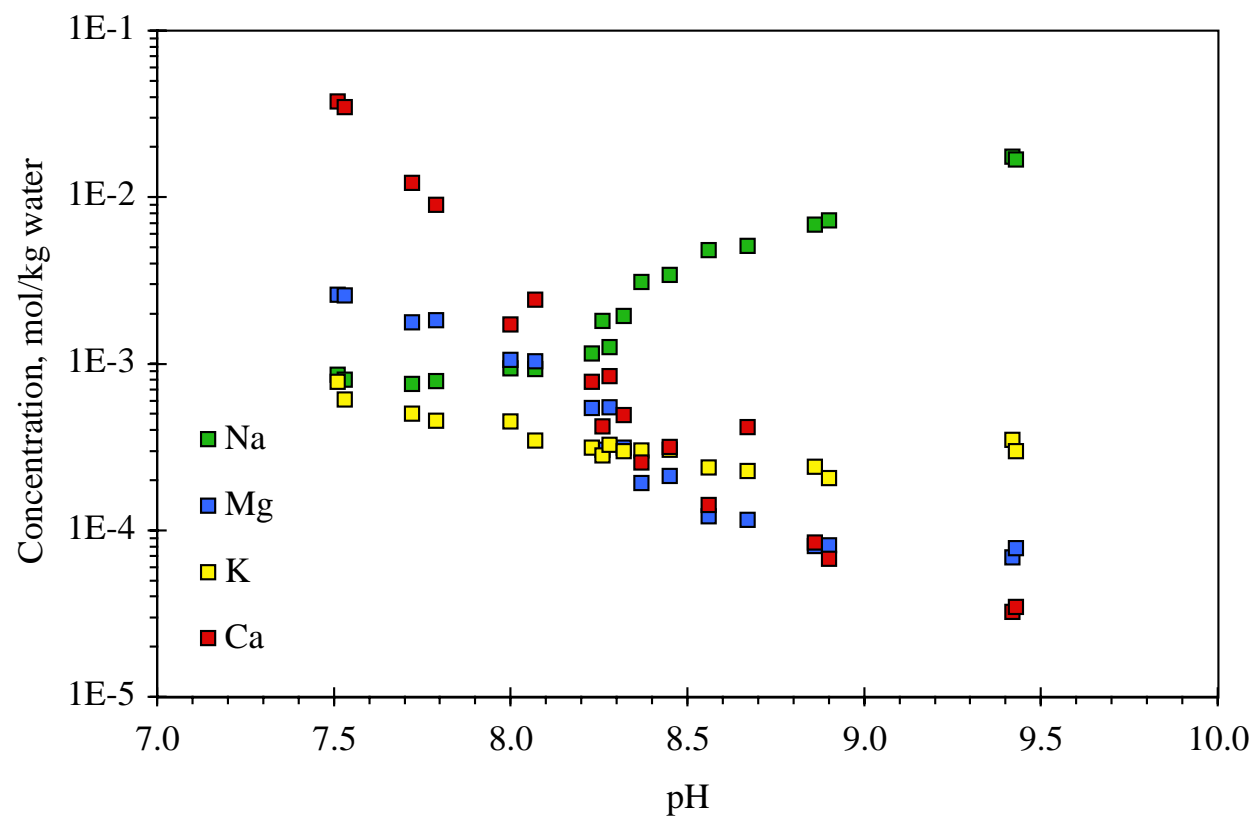

Figure 5. Major cation concentrations in the $10 \mathrm{mg} / \mathrm{L}$ strontium $\mathrm{U}-1 \mathrm{a}$ alluvium sorption samples.

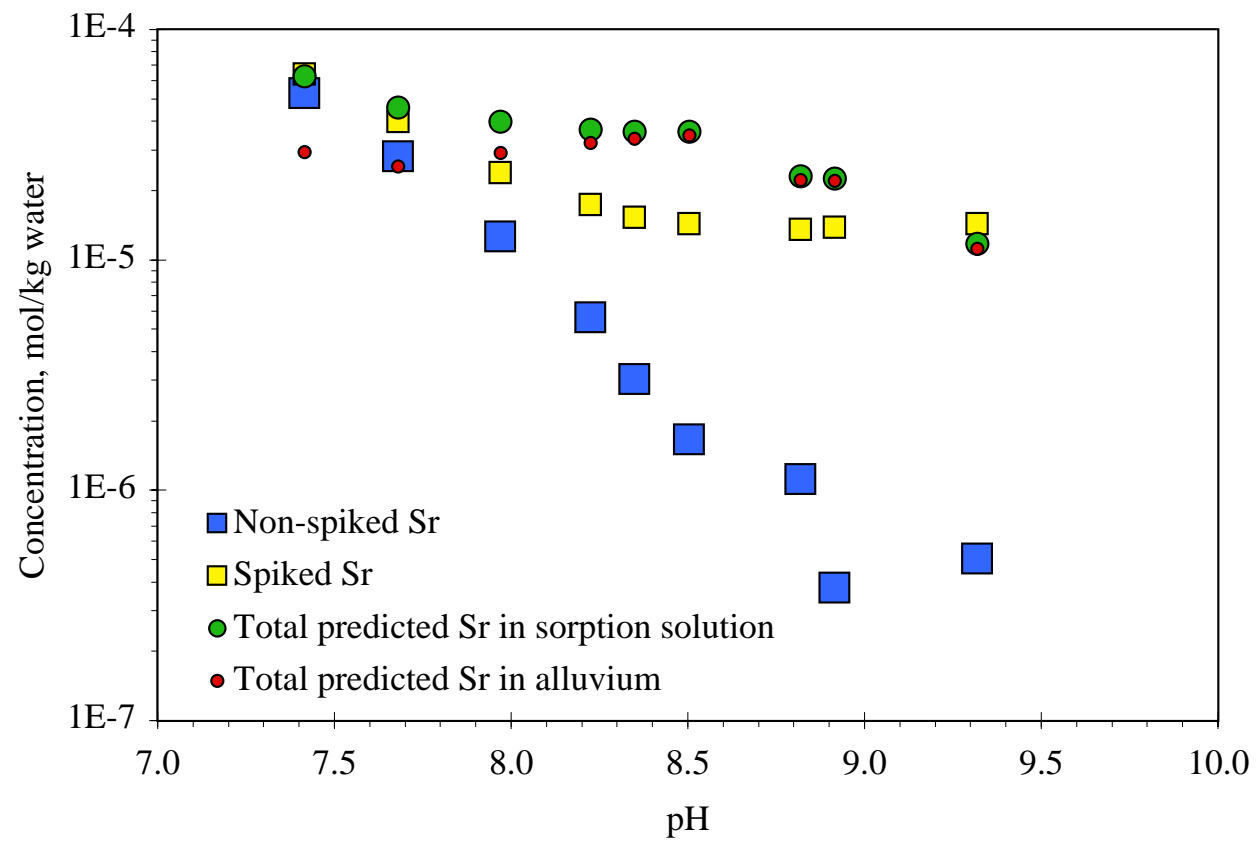

Figure 6. Measured and predicted concentrations of strontium in the $1 \mathrm{mg} / \mathrm{L}$ strontium $\mathrm{U}-1$ a alluvium sorption blanks. Aqueous + sorbed strontium in the non-spiked blanks was determined by predicting sorbed strontium from the measured non-spiked aqueous concentrations. Initial Sr refers to strontium in the initial solutions (Table 3). 


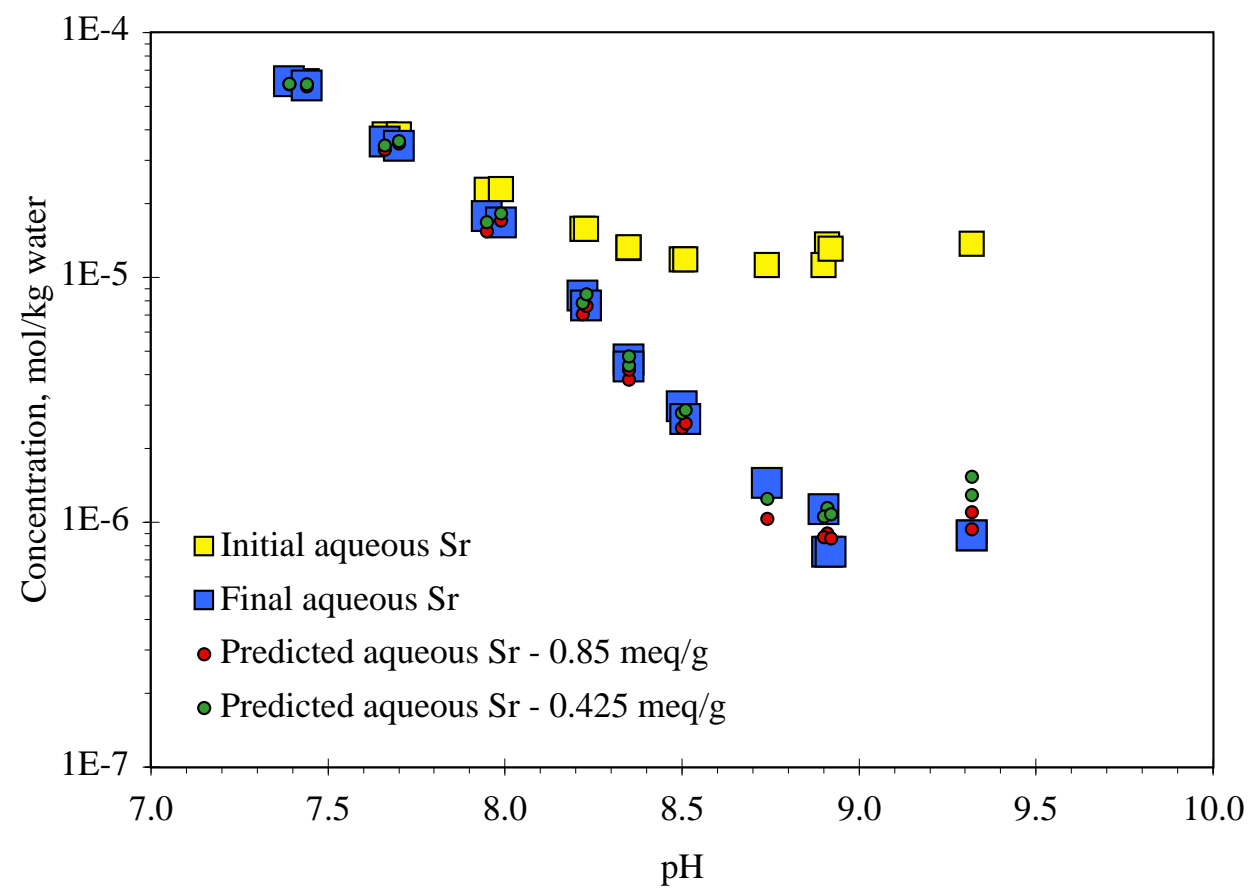

Figure 7. Measured and predicted concentrations of strontium in the $1 \mathrm{mg} / \mathrm{L}$ strontium U-1a alluvium sorption samples. Initial spiked strontium determined from non-apiked strontium in blanks + spike strontium. Predicted aqueous strontium calculated using $0.85 \mathrm{meq} / \mathrm{g}$ (red) and $0.425 \mathrm{meq} / \mathrm{g}$ (green) smectite cation exchange capacities.

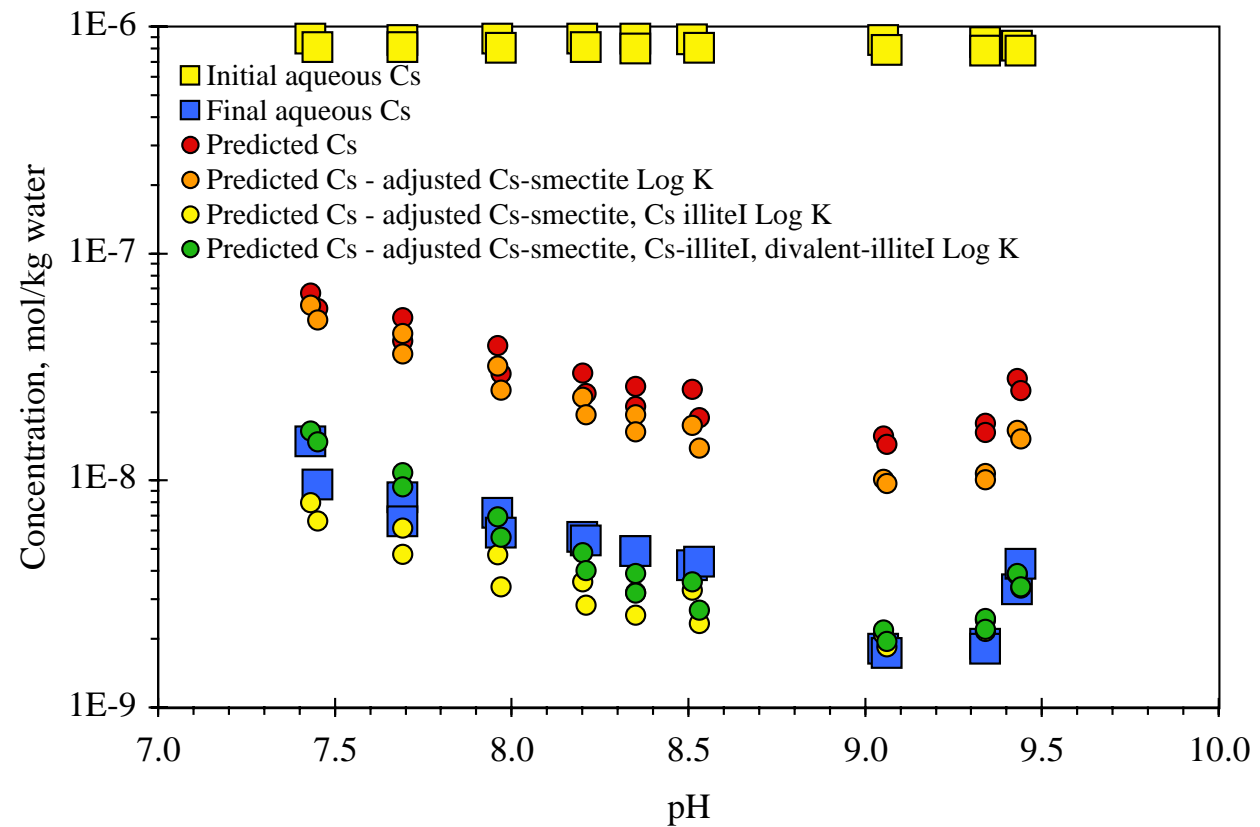

Figure 8. Measured and predicted concentrations of cesium in the $0.1 \mathrm{mg} / \mathrm{L}$ cesium $\mathrm{U}-1$ a alluvium sorption samples. Cesium-smectite $\log \mathrm{K}$ increased to 1.6. cesium-illite site I Log K increased by 1 to 6.7. Divalent cation-illite site I $\log \mathrm{K}$ increased to -0.75 from -2.05 . 


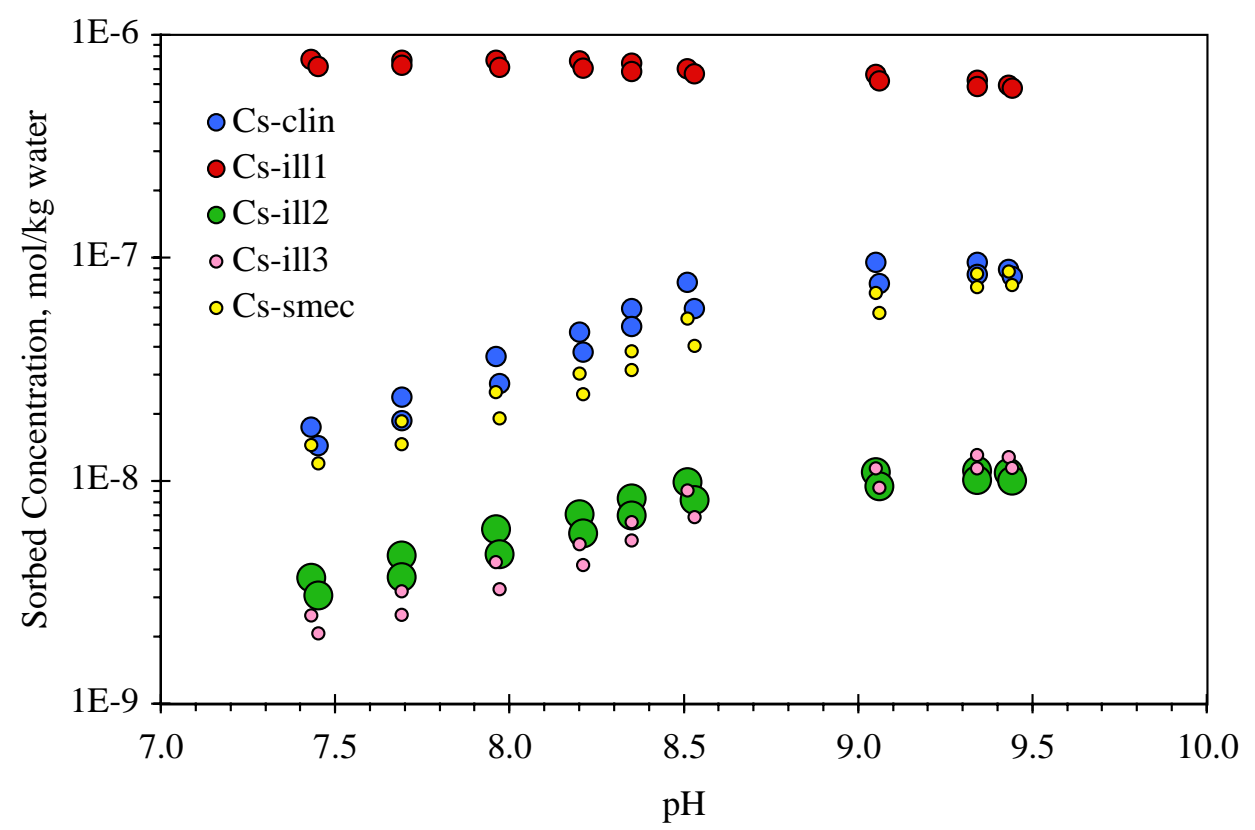

Figure 9. Predicted distribution of cesium on ion exchanging minerals in $0.1 \mathrm{mg} / \mathrm{L}$ cesium $\mathrm{U}-1 \mathrm{a}$ alluvium sorption samples. clin = clinoptilolite; ill1 = illite site I; ill2 = illite site II; ill3 = illite site III ; smec = smectite.

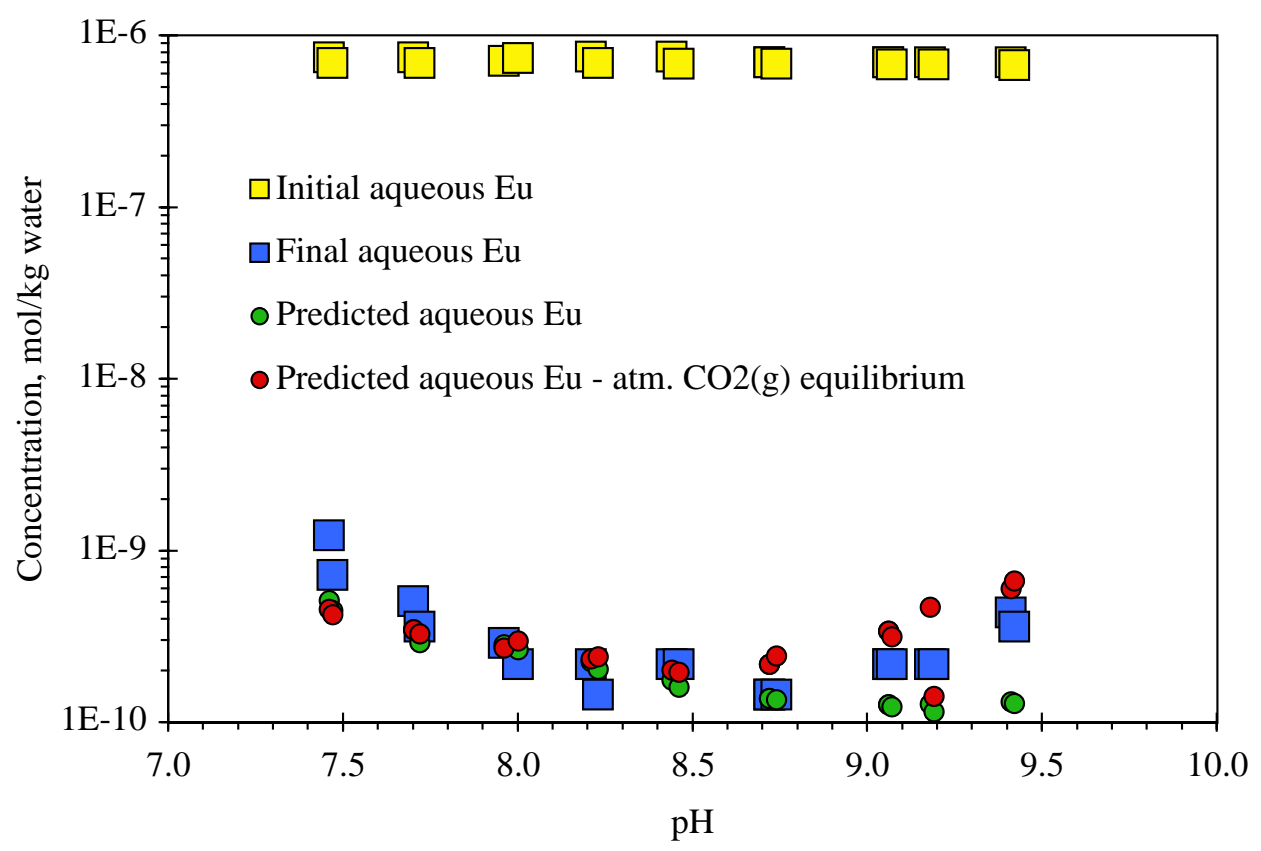

Figure 10. Measured and predicted concentrations of europium in the $0.1 \mathrm{mg} / \mathrm{L}$ europium $\mathrm{U}-1 \mathrm{a}$ alluvium sorption samples. Predicted aqueous europium calculated assuming equilibrium with calcite (green dots) or assuming equilibrium with atmospheric $\mathrm{CO}_{2}(\mathrm{~g})$ (red dots). 


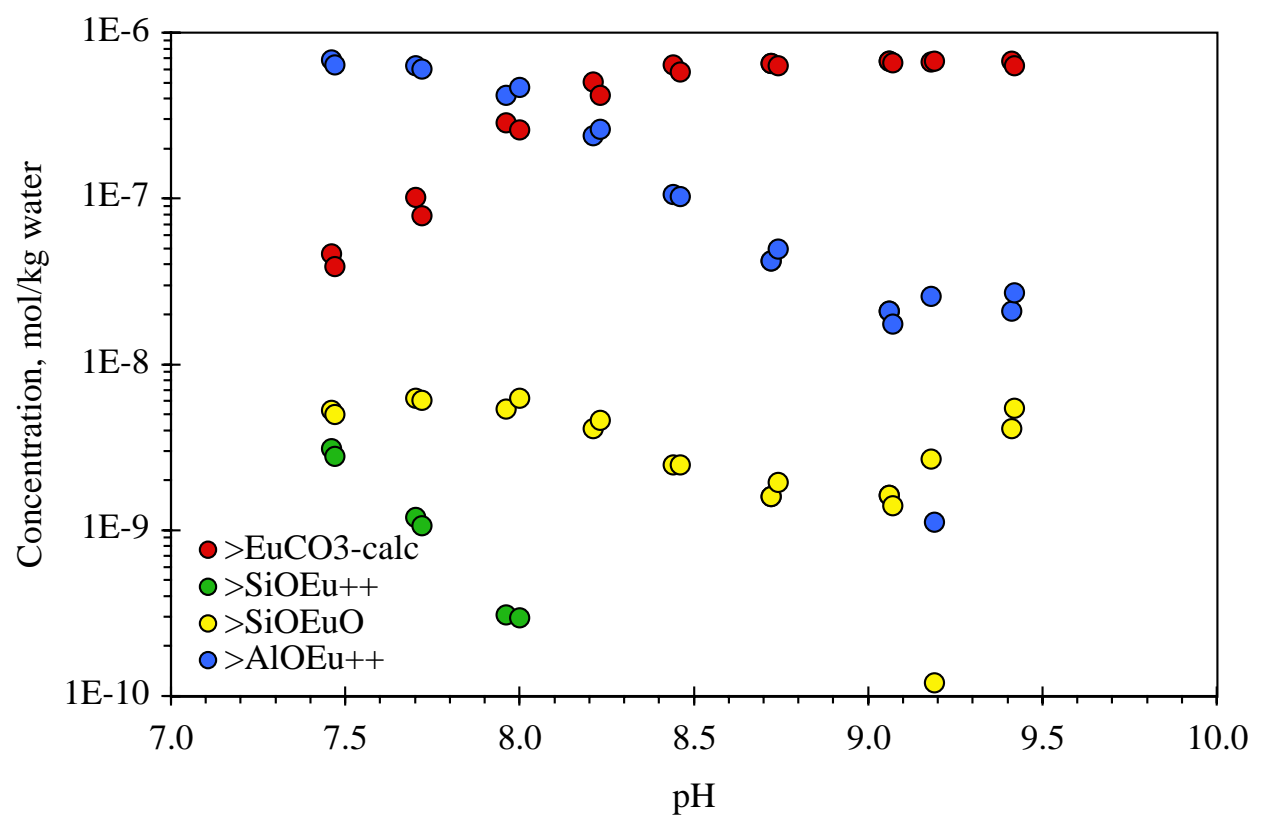

Figure 11. Predicted distribution of europium on radionuclide sorbing minerals in the $0.1 \mathrm{mg} / \mathrm{L}$ europium $\mathrm{U}-1$ a alluvium sorption samples. $>\mathrm{SiOEu}^{2+},>\mathrm{SiOEuO}$, and $>\mathrm{AlOEu}$ are smectite surface sites, $>\mathrm{EuCO} 3-$ calc are calcite surface sites.

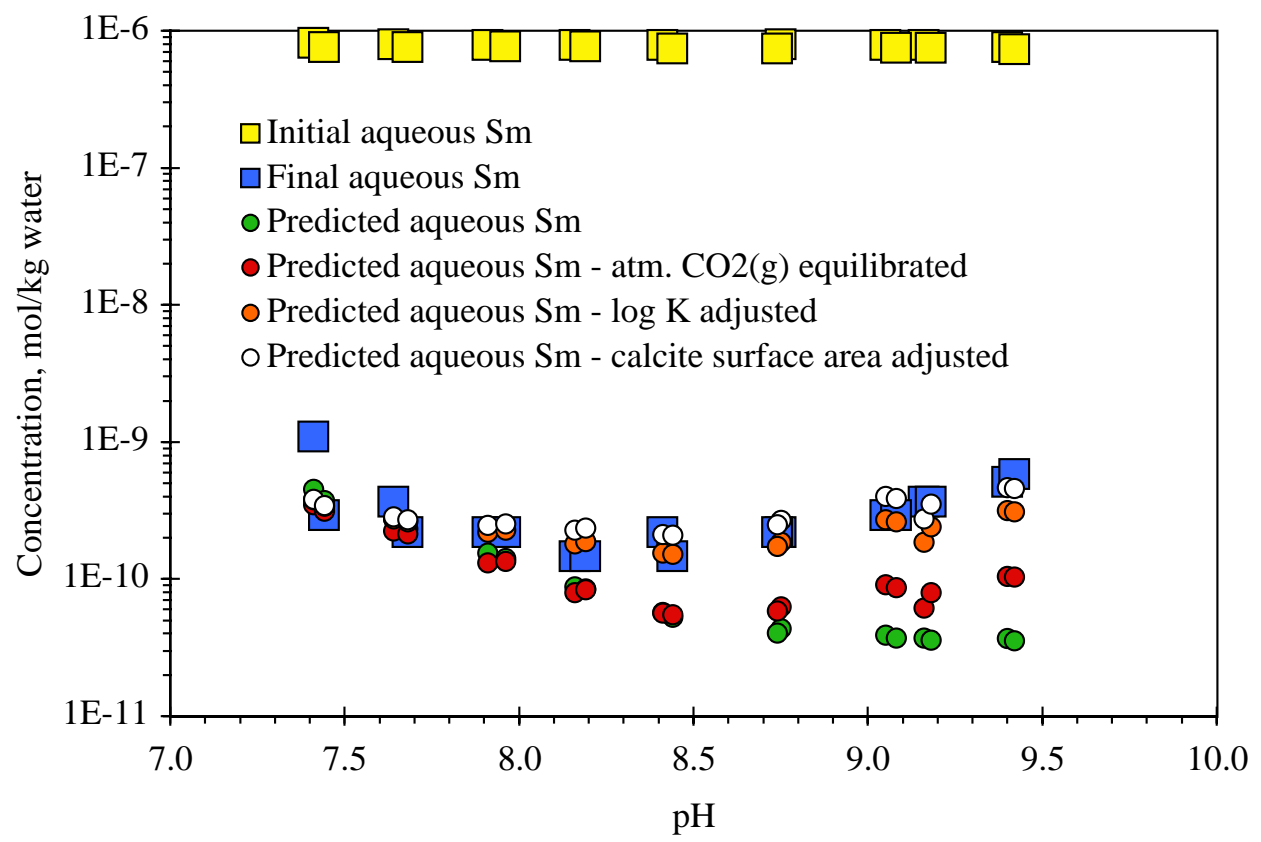

Figure 12. Measured and predicted concentrations of samarium in the $0.1 \mathrm{mg} / \mathrm{L}$ samarium $\mathrm{U}-1 \mathrm{a}$ alluvium sorption samples. Predicted aqueous samarium calculated assuming solution equilibrium with calcite (green), assuming solution equilibrium with atmospheric $\mathrm{CO}_{2}(\mathrm{~g})$ (red), assuming solution equilibrium with atmospheric $\mathrm{CO}_{2}(\mathrm{~g})$ and adjusting samarium-calcite $\log \mathrm{K}$ to be the same as for europium (orange), and assuming solution equilibrium with atmospheric $\mathrm{CO}_{2}(\mathrm{~g})$ and adjusting calcite reactive surface area from 2.2 to $0.5 \mathrm{~m}^{2} / \mathrm{g}$ (white). 


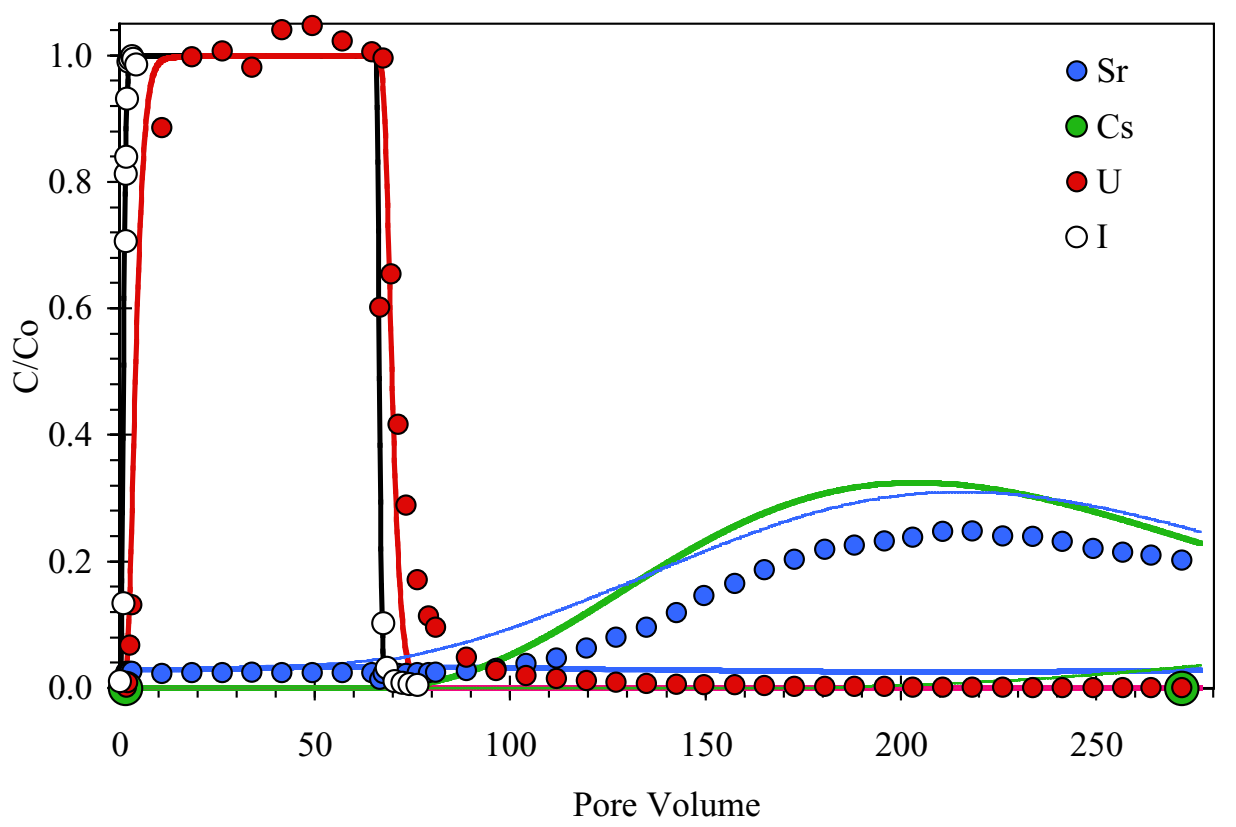

Figure 13. Breakthrough data for Experiment \#1 (U-1a alluvium). Lines represent the fit to data using our mechanistic model and reaction constants and mineral reactivities defined in Appendix E. Thin lines represent model fits using adjusted constants defined in Table 9.

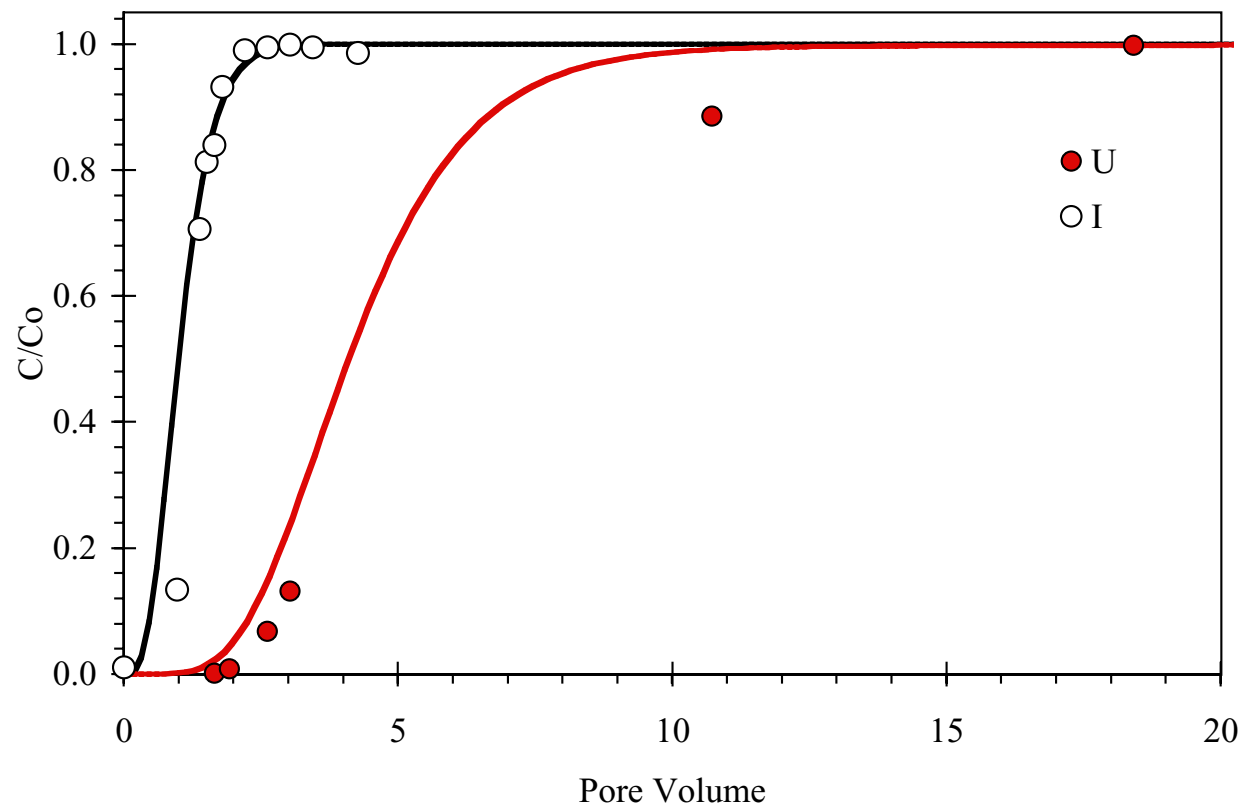

Figure 14. Iodide and uranium breakthrough data for Experiment \#1 (U-1a alluvium), 0 to 20 pore volume range. Lines represent the fit to data using our mechanistic model and reaction constants and mineral reactivities defined in Appendix E. 


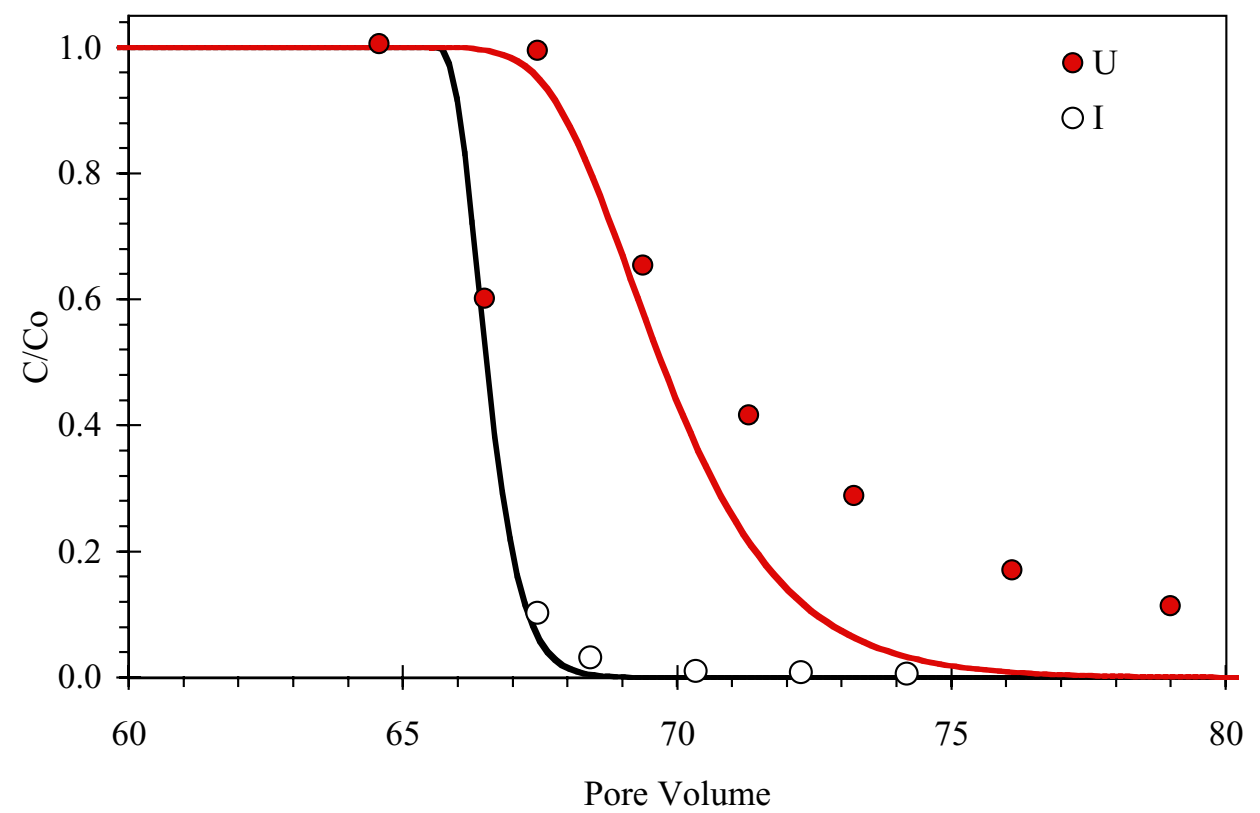

Figure 15. Iodide and uranium breakthrough data for Experiment \#1 (U-1a alluvium), 60 to 80 pore volume range. Lines represent the fit to data using our mechanistic model and reaction constants and mineral reactivities defined in Appendix E.

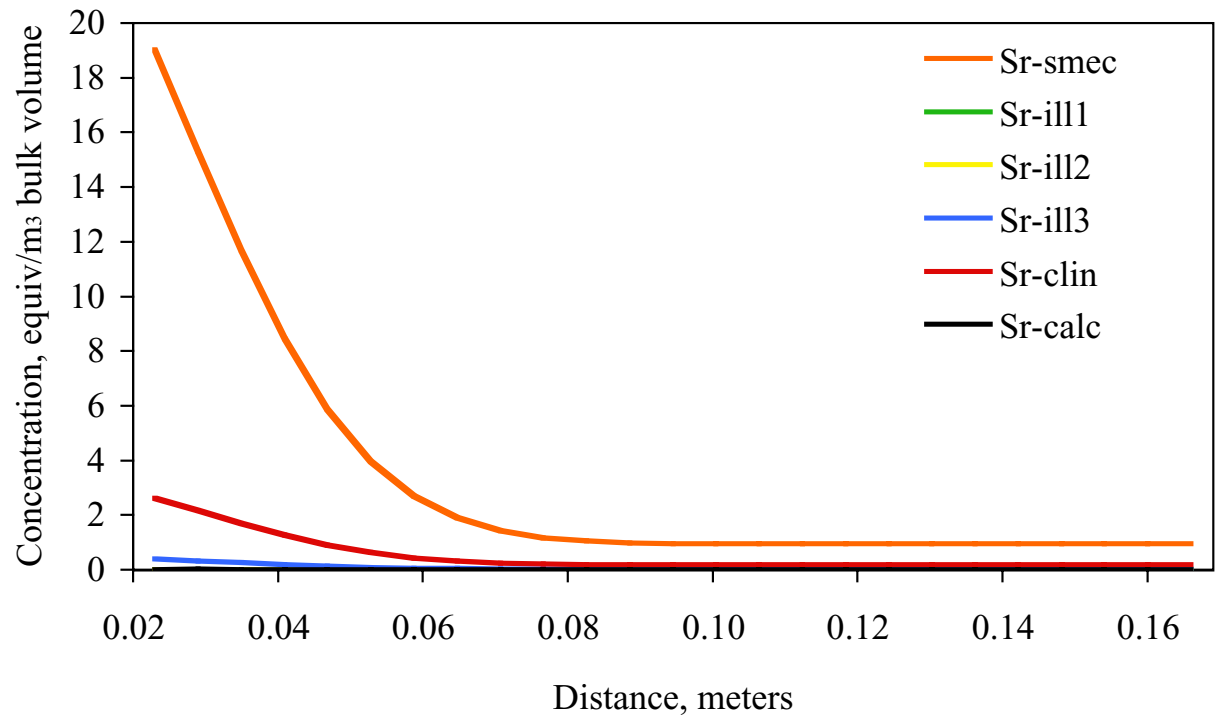

Figure 16. Spatial distribution and strontium associations with minerals in column Experiment \#1 (U-1a alluvium). Lines represent the fit to data using our mechanistic model and reaction constants and mineral reactivities defined in Appendix E. Spatial distribution at 65 pore volumes is shown. clin = clinoptilolite; ill1 = illite site I; ill2 = illite site II; ill3 = illite site III ; smec = smectite; calc = calcite . 


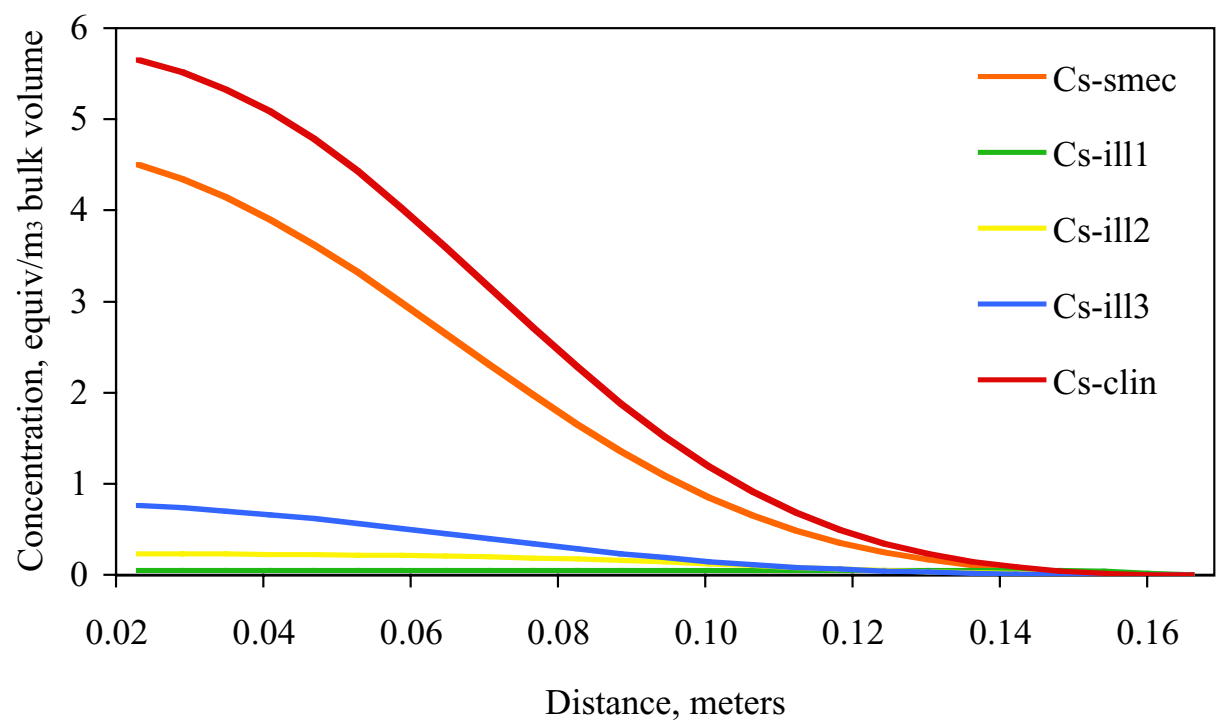

Figure 17. Spatial distribution and cesium associations with minerals in column Experiment \#1 (U-1a alluvium). Lines represent the fit to data using our mechanistic model and reaction constants and mineral reactivities defined in Appendix E. Spatial distribution at 65 pore volumes is shown. clin = clinoptilolite; ill1 = illite site I; ill2 = illite site II; ill3 = illite site III ; smec = smectite. 


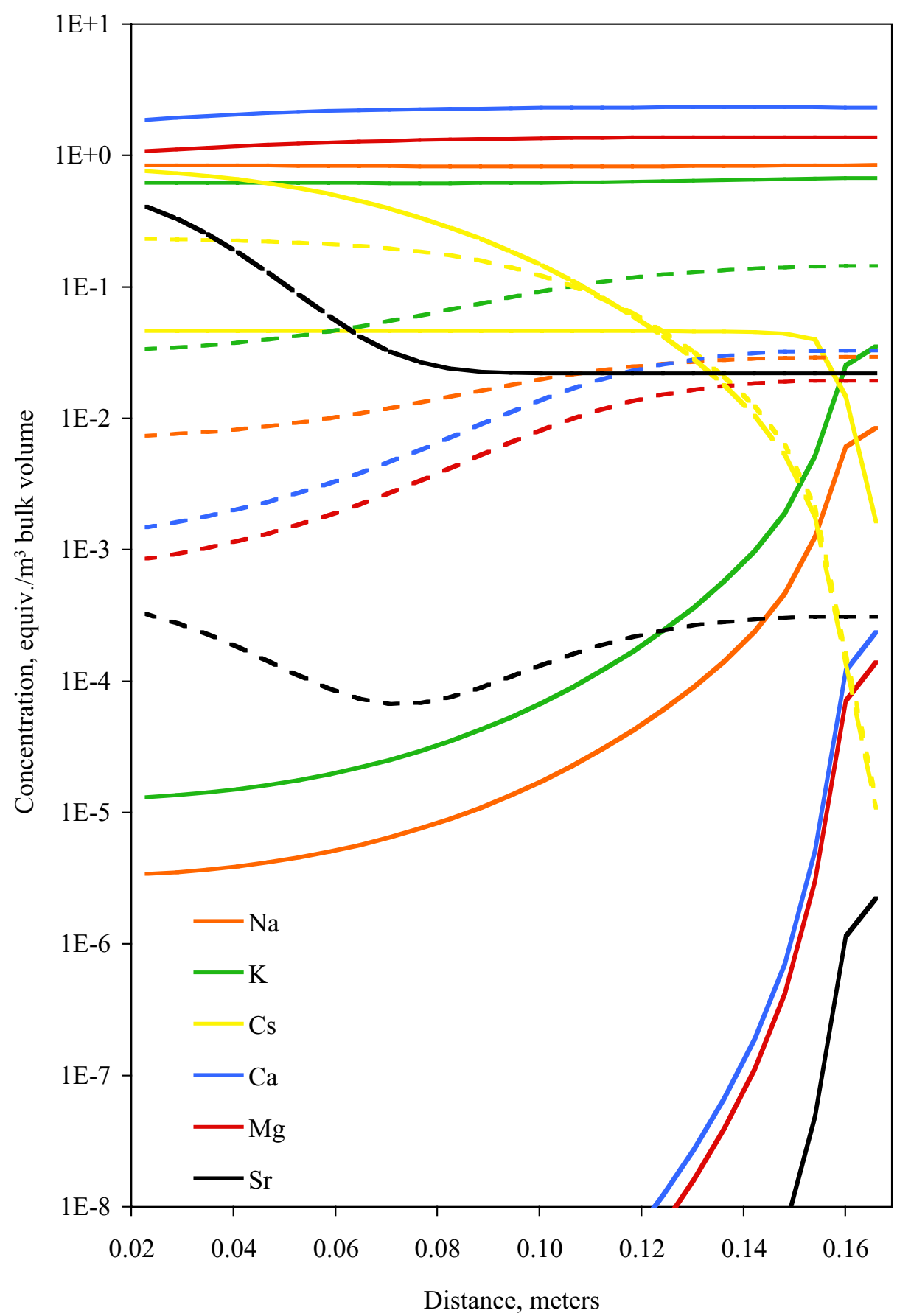

Figure 18. Cations occupying ion exchange sites on illite in column Experiment \#1 (U-1a alluvium). Lines represent the fit to data using our mechanistic model and reaction constants and mineral reactivities defined in Appendix E. Spatial distribution at 65 pore volumes is shown. Solid lines represent the ion exchange site that preferentially sorbs cesium. Other sites are represented by long-dashed and short-dashed lines. 


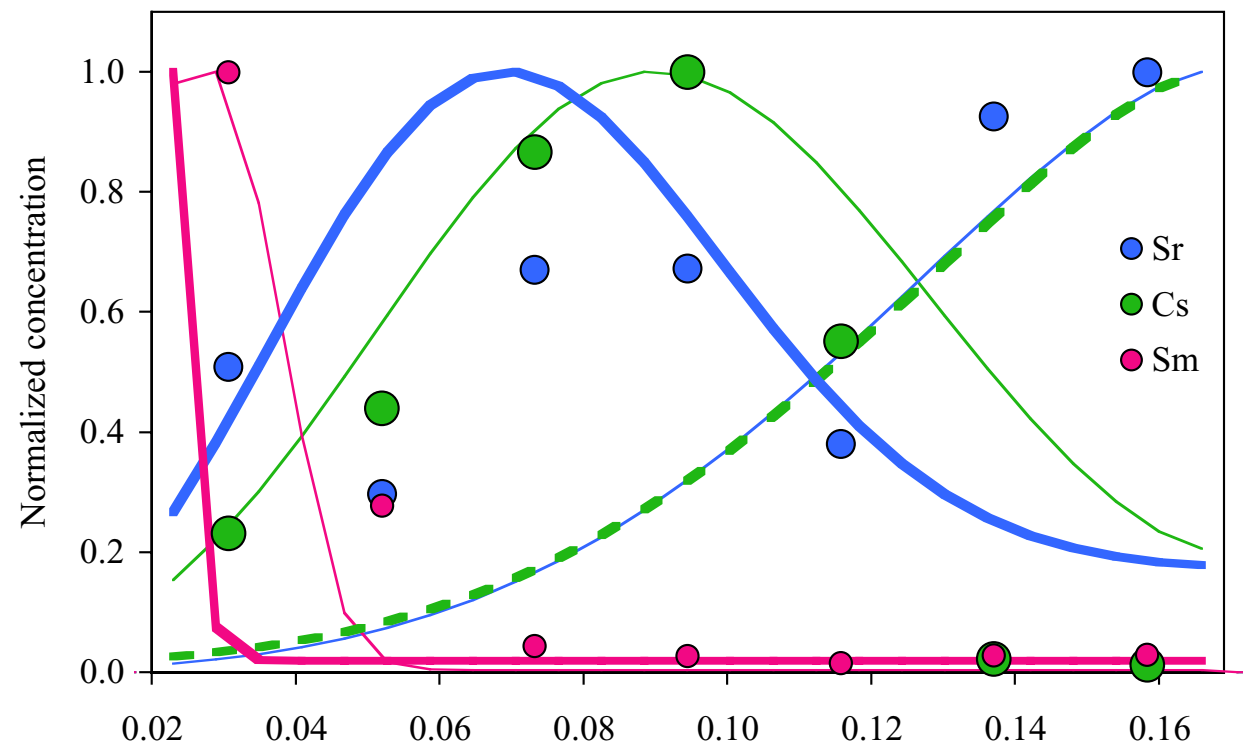

Distance, meters

Figure 19. Results of SIMS analysis of column Experiment \#1 (U-1a alluvium, 275 pore volumes). Thick lines represent the fit to data using our mechanistic model and reaction constants and mineral reactivities defined in Appendix E (Cs line dashed to reveal other data fit). Thin lines represent model fits using adjusted constants defined in Table 9.

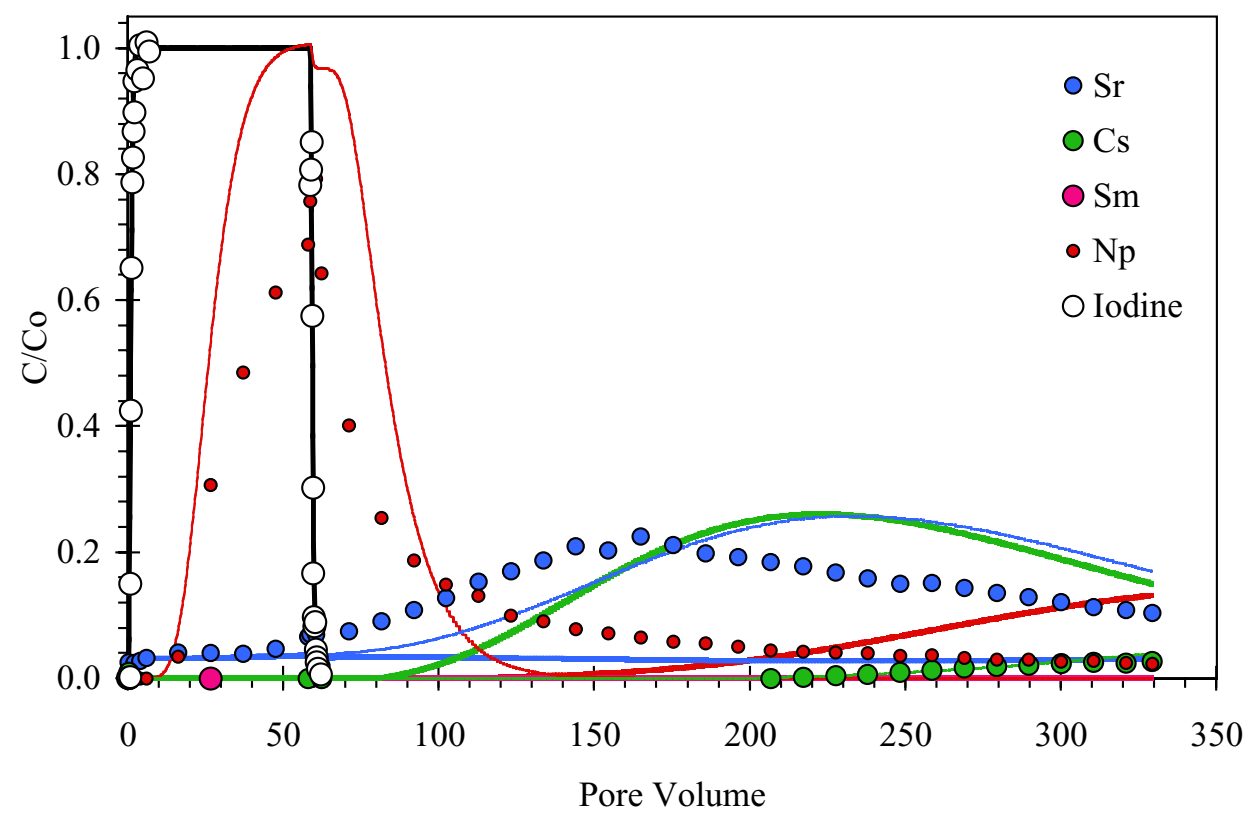

Figure 20. Breakthrough data for Experiment \#2 (U-1a alluvium). Thick lines represent the fit to data using our mechanistic model and reaction constants and mineral reactivities defined in Appendix E. Thin lines represent model fits using adjusted constants defined in Table 9. 


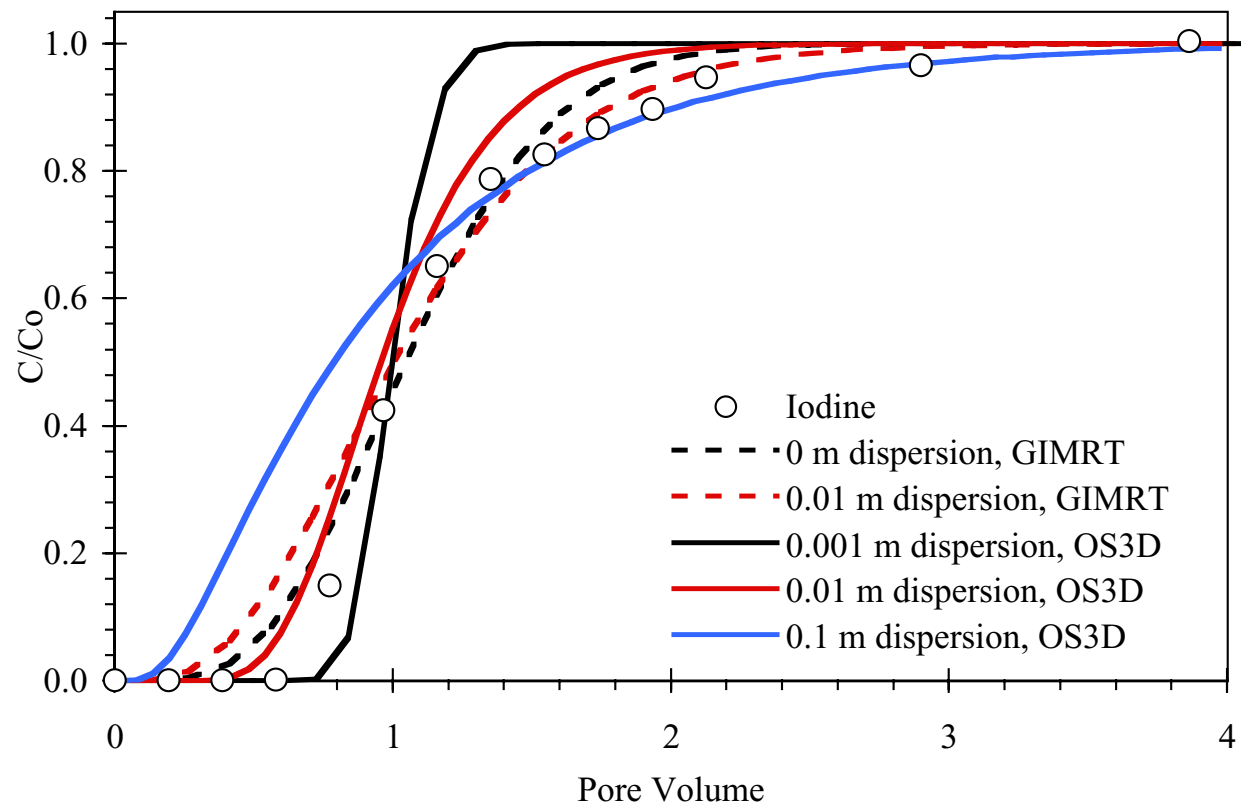

Figure 21. Iodide breakthrough data for Experiment \#2 (U-1a alluvium), 0 to 4 pore volume range. Lines represent predicted breakthrough based on the GIMRT and OS3D models and several dispersivities.

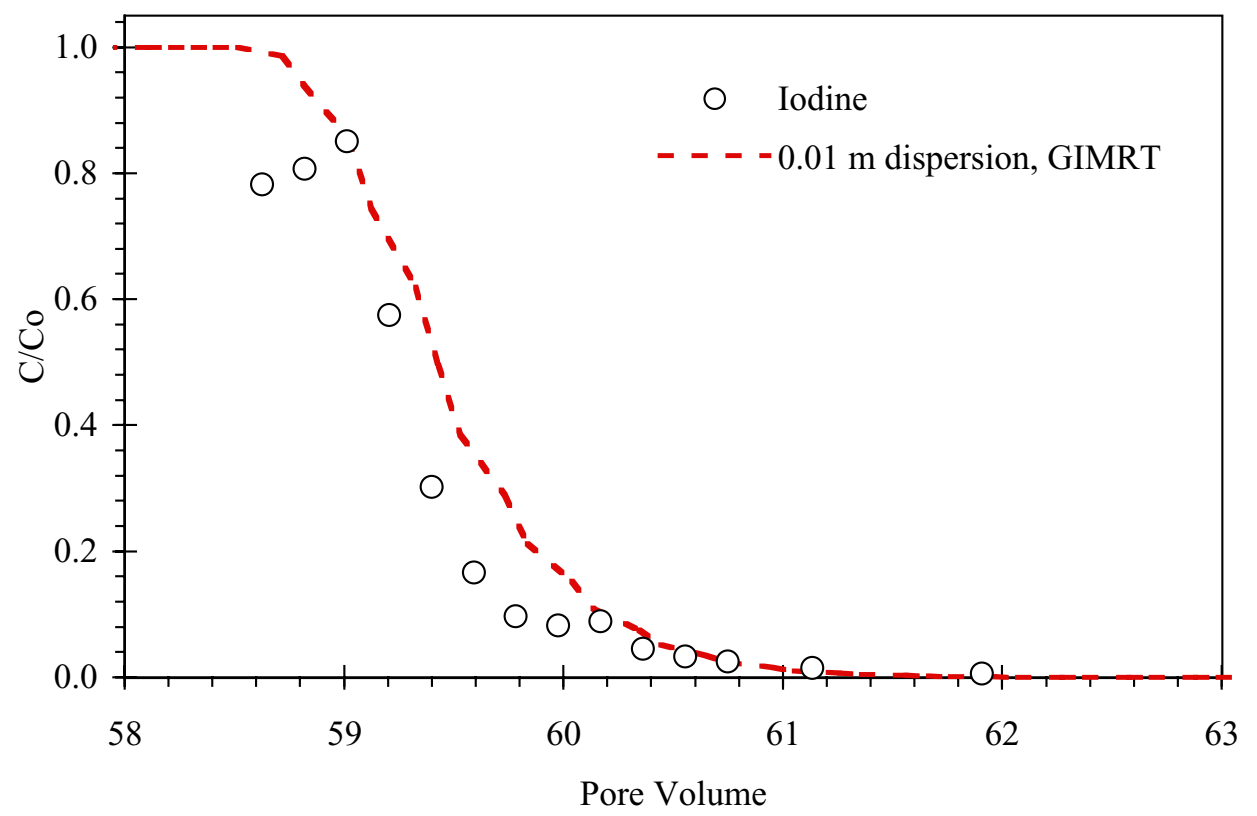

Figure 22. Iodide breakthrough data for Experiment \#2 (U-1a alluvium), 58 to 63 pore volume range. Lines represent predicted breakthrough based on the GIMRT models and a dispersion of 0.01 meters. 


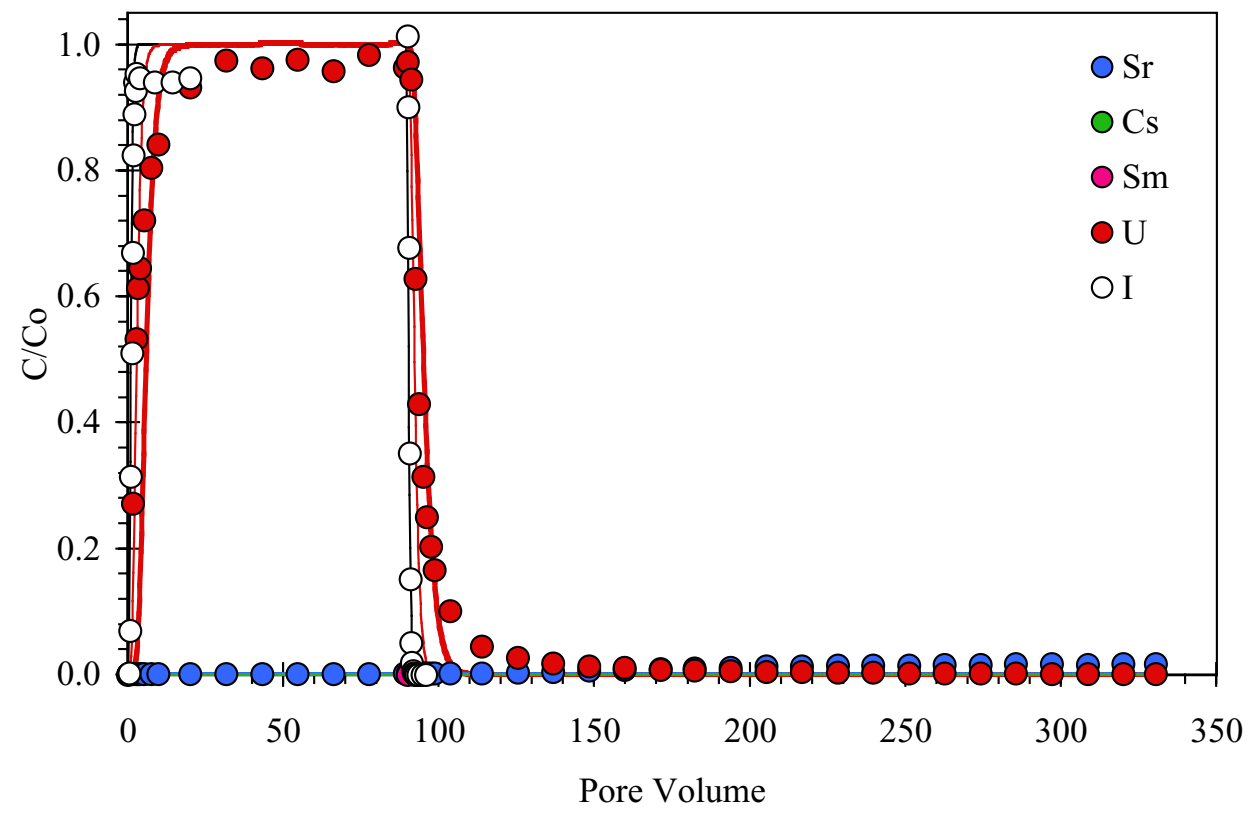

Figure 23. Breakthrough data for Experiment \#3 (UE-5n alluvium). Thick lines represent the fit to data using our mechanistic model and reaction constants and mineral reactivities defined in Appendix E. Thin lines represent model fits using adjusted constants defined in Table 9.

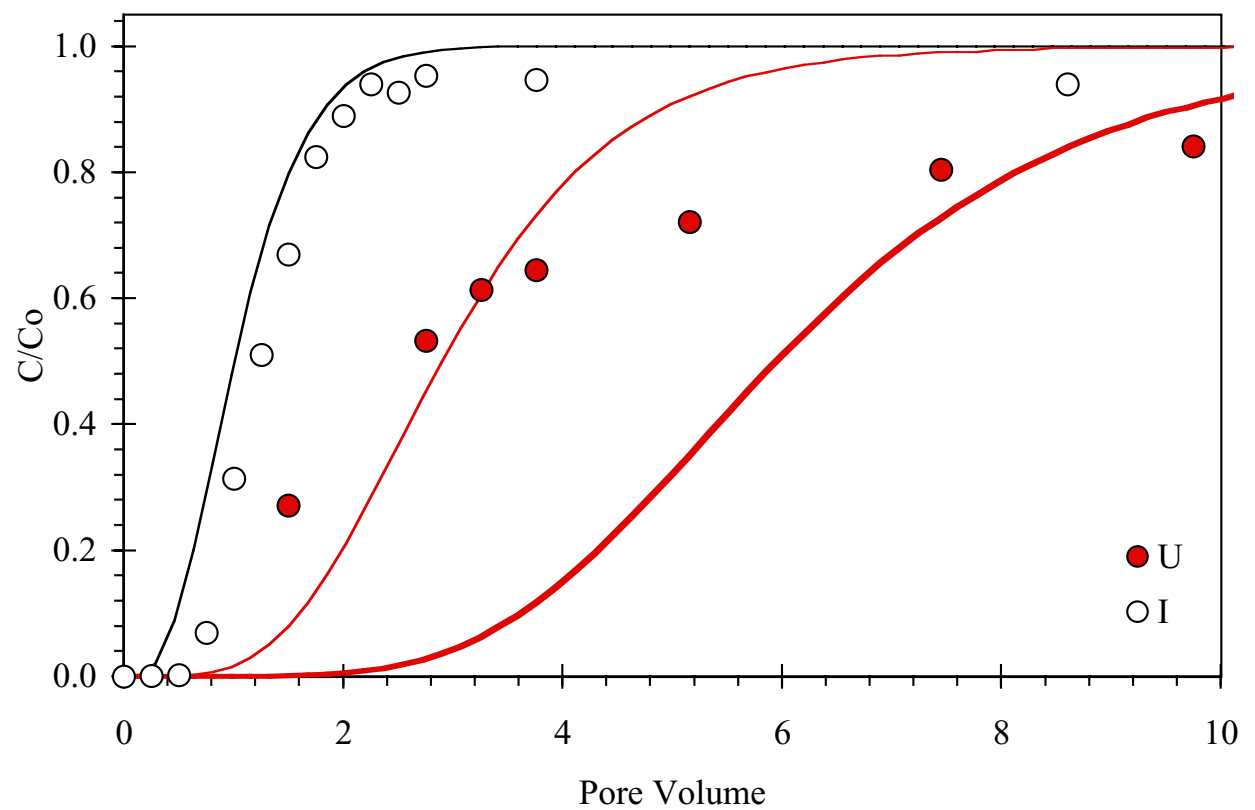

Figure 24. Iodide and uranium breakthrough data for Experiment \#3 (UE-5n alluvium), 0 to 10 pore volume range. Thick lines represent the fit to data using our mechanistic model and reaction constants and mineral reactivities defined in Appendix E. Thin lines represent model fits using adjusted constants defined in Table 9. 


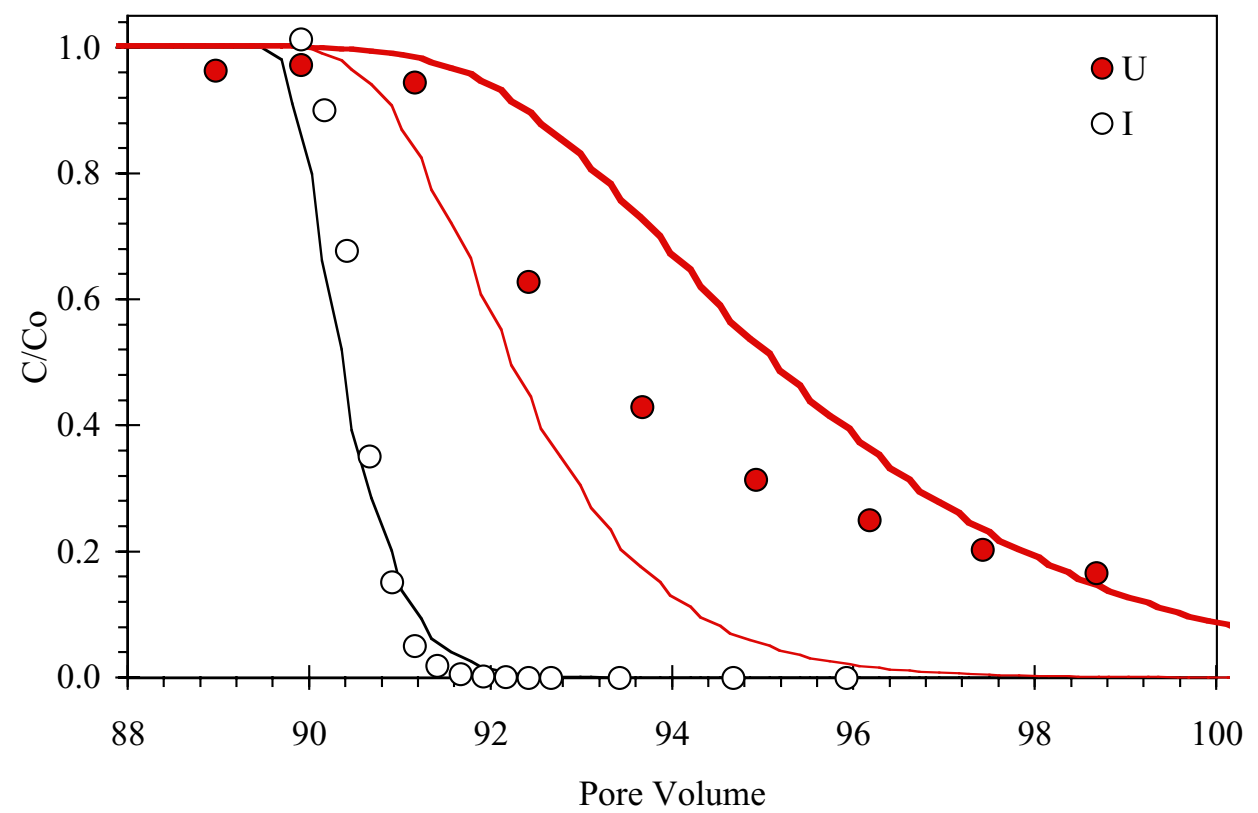

Figure 25. Iodide and uranium breakthrough data for Experiment \#3 (UE-5n alluvium), 88 to 100 pore volume range. Thick lines represent the fit to data using our mechanistic model and reaction constants and mineral reactivities defined in Appendix E. Thin lines represent model fits using adjusted constants defined in Table 9.

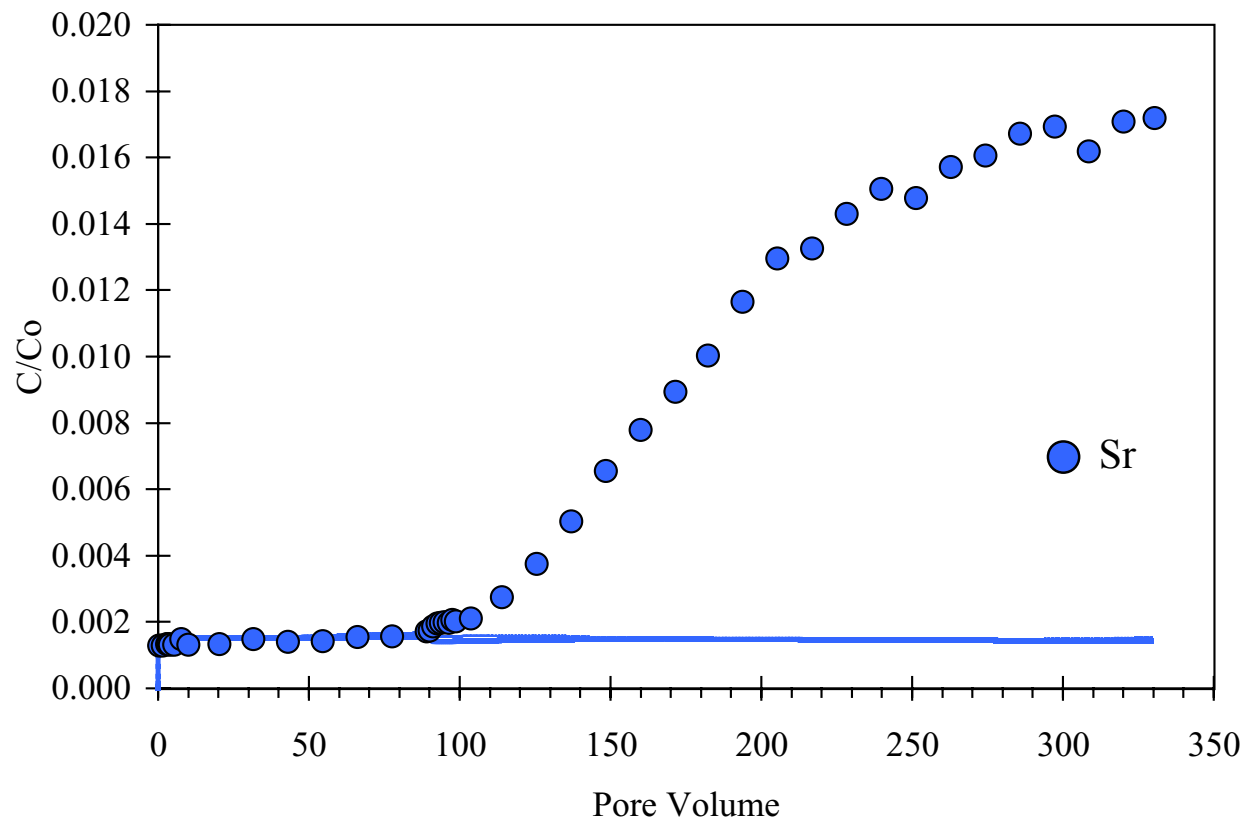

Figure 26. Strontium breakthrough data for Experiment \#3 (UE-5n alluvium). Thick lines represent the fit to data using our mechanistic model and reaction constants and mineral reactivities defined in Appendix E. Thin lines represent model fits using adjusted constants defined in Table 9. 


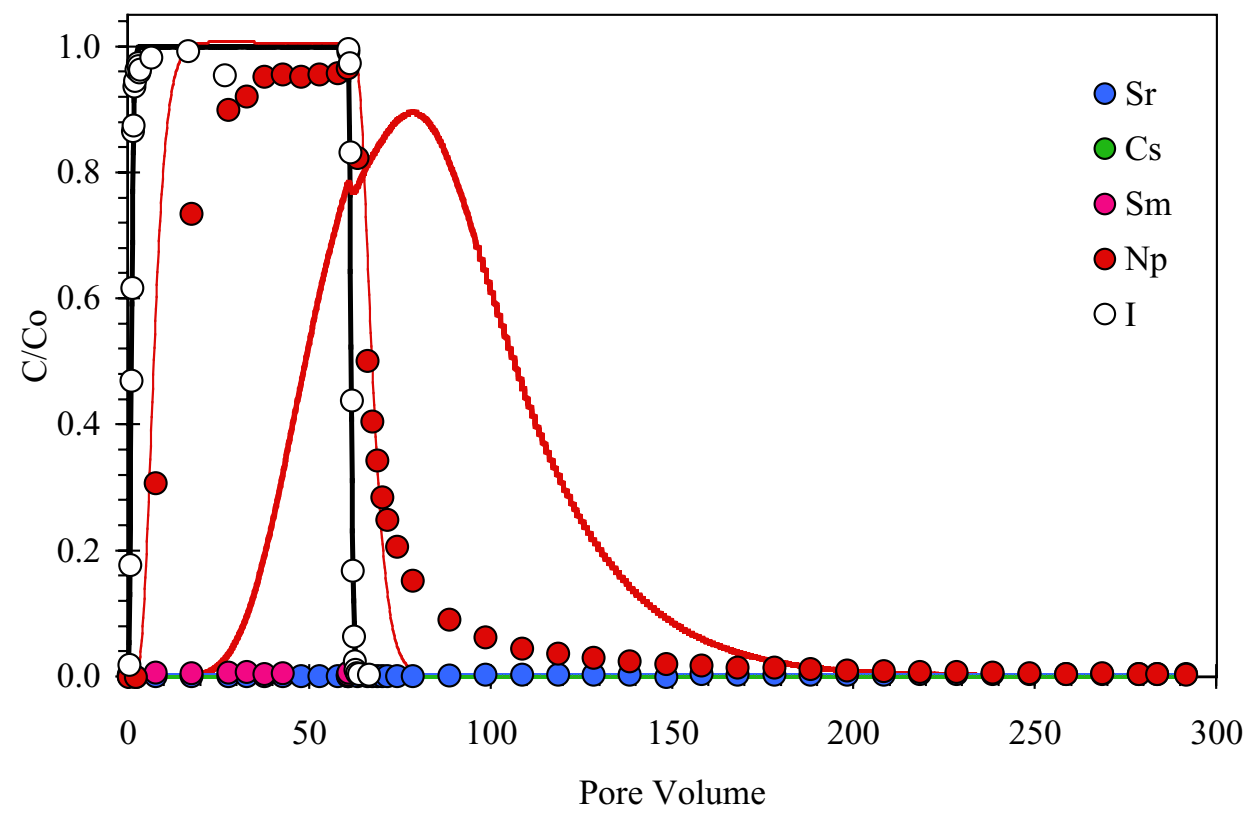

Figure 27. Breakthrough data for Experiment \#4 (UE-5n alluvium). Thick lines represent the fit to data using our mechanistic model and reaction constants and mineral reactivities defined in Appendix E. Thin lines represent model fits using adjusted constants defined in Table 9.

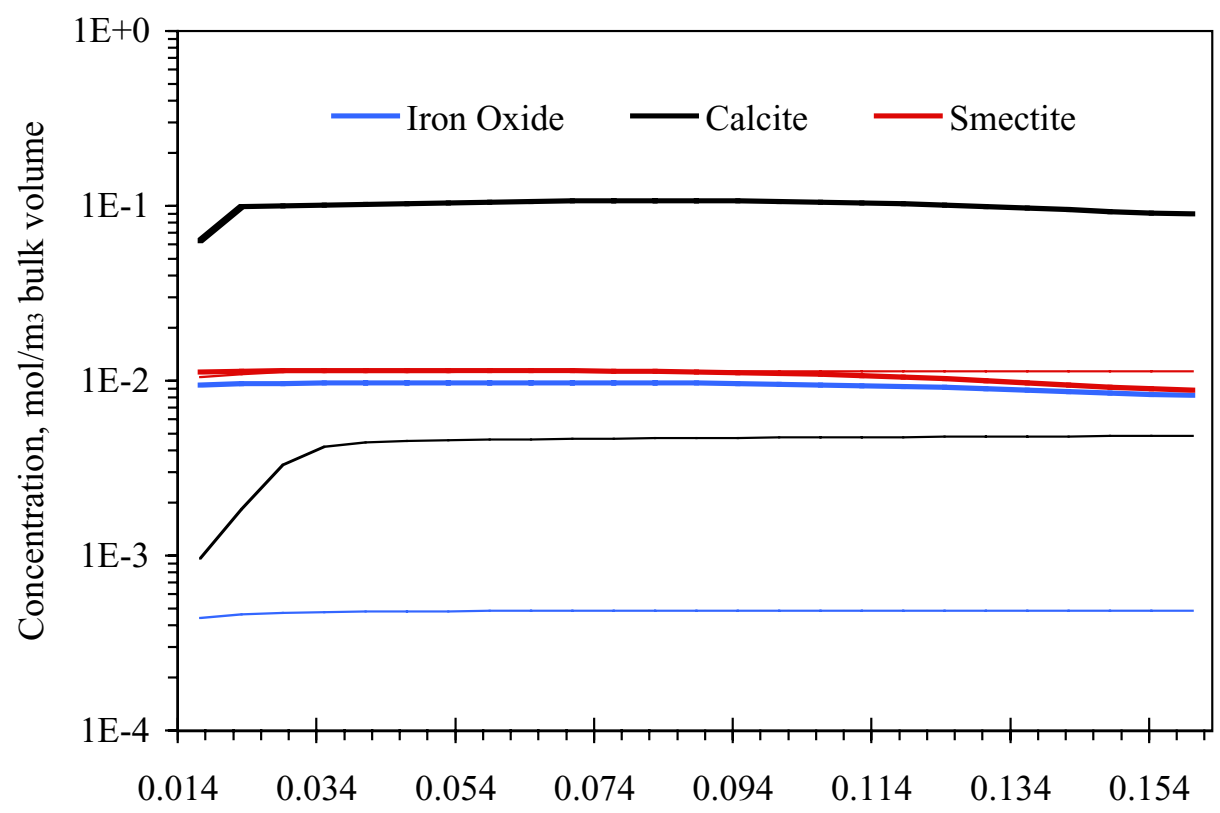

Distance, meters

Figure 28. Predicted profile of neptunium distribution at 60 pore volumes for Experiment \#4 (UE-5n alluvium). Thick lines represent the fit to data using our mechanistic model and reaction constants and mineral reactivities defined in Appendix E. Thin lines represent model fits using adjusted constants defined in Table 9. 


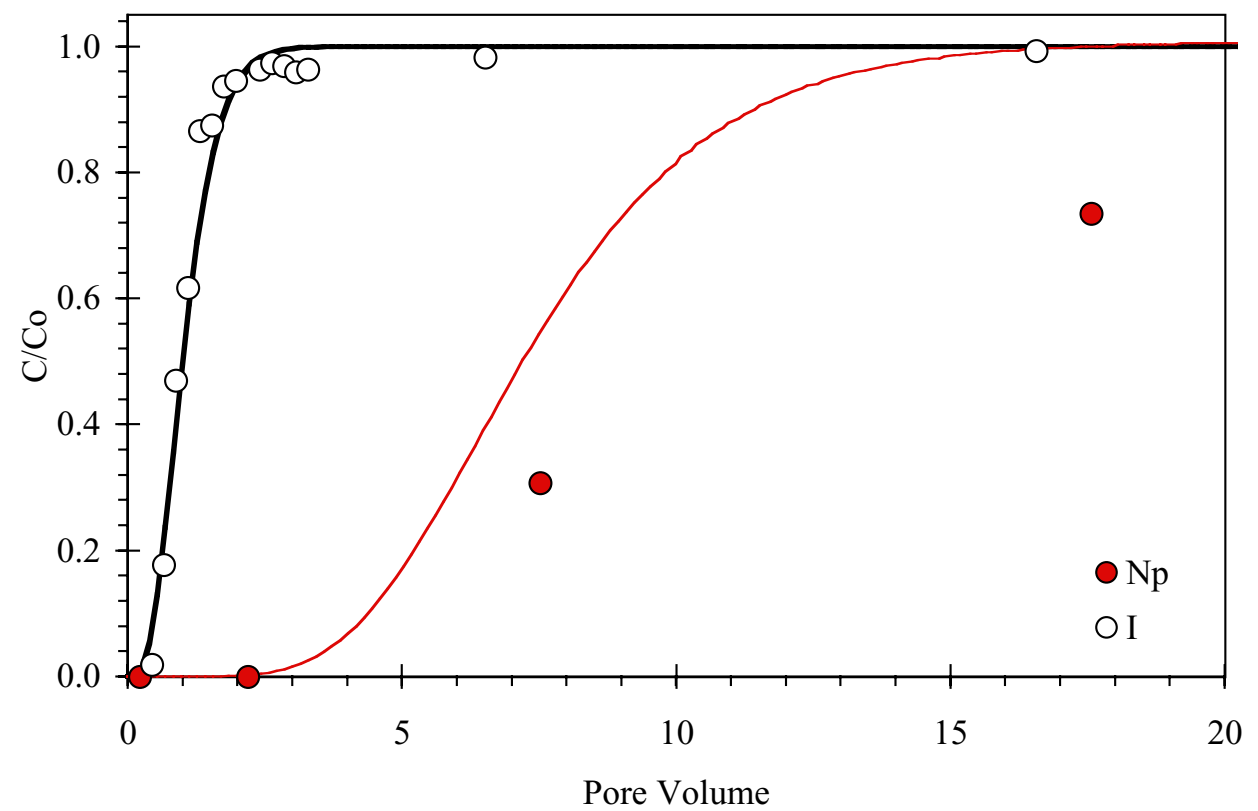

Figure 29. Iodide and neptunium breakthrough data for Experiment \#4 (UE-5n alluvium), 0 to 20 pore volume range. Thick lines represent the fit to data using our mechanistic model and reaction constants and mineral reactivities defined in Appendix E. Thin lines represent model fits using adjusted constants defined in Table 9.

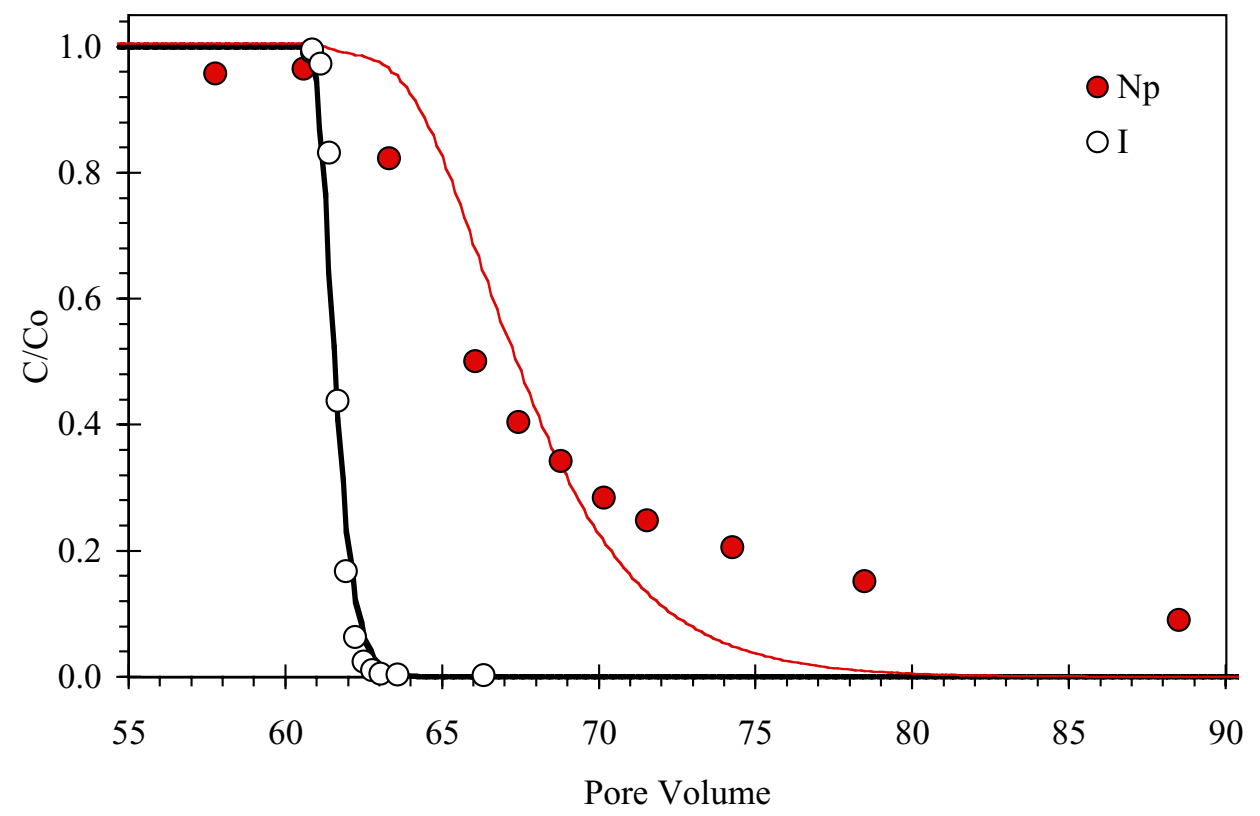

Figure 30. Iodide and neptunium breakthrough data for Experiment \#4 (UE-5n alluvium), 55 to 90 pore volume range. Thick lines represent the fit to data using our mechanistic model and reaction constants and mineral reactivities defined in Appendix E. Thin lines represent model fits using adjusted constants defined in Table 9. 


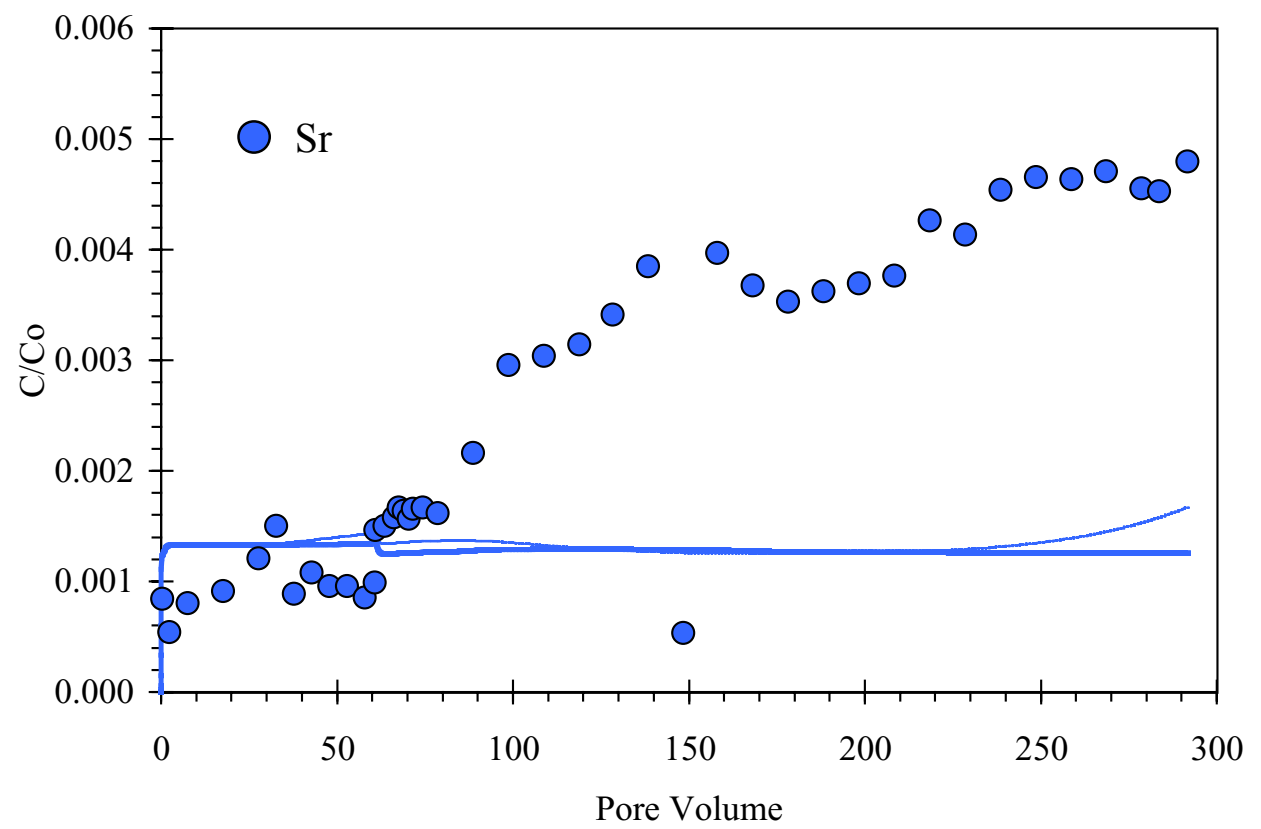

Figure 31. Strontium breakthrough data for Experiment \#4 (UE-5n alluvium). Thick lines represent the fit to data using our mechanistic model and reaction constants and mineral reactivities defined in Appendix E. Thin lines represent model fits using adjusted constants defined in Table 9. 


\section{Appendix A. Column Breakthrough Data}

The following appendices list all measured and derived data from the flow-through column experiments performed on $\mathrm{U}-1 \mathrm{a}$ and $\mathrm{UE}-5 \mathrm{n}$ alluvium. The following notes identify and clarify various table entries.

The alluvium volume is the mass of dried alluvium (in grams) in the column divided by the measured average mineral density (in grams per milliliter).

The column volume is calculated by the measured dimensions of the column using the equation: volume $=\pi \times(\text { diameter } / 2)^{2} \times$ length.

The column pore volume is the column volume minus the alluvium volume.

The porosity is calculated as the pore volume in milliliters divided by the column volume in milliliters multiplied by 100 .

The pore volume is defined as the column pore volume plus the volume in the tubing from the inflow to the outflow fraction collector in milliliters.

C/Co for the sorbing elements is the measured quantities in ppb from the outflow fractions divided by the measured quantities in ppb from the starting sorption solution.

The accumulated run time is the experiment length in hours.

na indicates samples not analyzed.

nd indicates analyzed values below detection limit of ICP-MS.

The flow through solution used in the experiments is a synthetic Frenchman Flat groundwater to which the sorbers of interest (Iodide, Strontium, Cesium, Samarium, and either Uranium or Neptunium) have been added in varying concentrations (see Table 5). The synthetic solution has roughly the same ionic strength, $\mathrm{pH}$, and $\mathrm{pH}$-buffering capacity as typical Frenchman Flat groundwater. 
Table A-1. Flow-through Experiment \#1 data.

UGTA Reactive-Transport Column Experiment \#1 using alluvium U-1A

Column "A" Dimension (IDxL):0.9906 cm x $14.895 \mathrm{~cm}$

Alluvium mass (g) $\quad 15.34$

Alluvium volume (mL) $\quad 5.90$

Column volume $(\mathrm{mL}) \quad 11.48$

Column pore volume $(\mathrm{mL}) \quad 5.58$

Porosity (\%) 48.61

Pore volume $(\mathrm{mL}) \quad 7.28$

\begin{tabular}{|c|c|c|c|c|c|c|c|}
\hline Sample\# & $\begin{array}{l}\text { Accumulated run } \\
\text { time (hrs) }\end{array}$ & $\begin{array}{l}\text { Column } \\
\text { pore } \\
\text { volumes }\end{array}$ & $\begin{array}{l}\mathrm{C} / \mathrm{Co} \\
\text { Iodide }\end{array}$ & $\begin{array}{c}\mathrm{C} / \mathrm{Co} \\
\text { Strontium }\end{array}$ & $\begin{array}{l}\mathrm{C} / \mathrm{Co} \\
\text { Cesium }\end{array}$ & $\begin{array}{c}\mathrm{C} / \mathrm{Co} \\
\text { Samarium }\end{array}$ & $\begin{array}{c}\mathrm{C} / \mathrm{Co} \\
\text { Uranium }\end{array}$ \\
\hline $1 \mathrm{~S}-1$ & 1.17 & 1.25 & $1.44 \mathrm{E}-01$ & na & na & na & na \\
\hline $1 \mathrm{~S}-2$ & 1.42 & 1.79 & $7.56 \mathrm{E}-01$ & $2.43 \mathrm{E}-02$ & nd & nd & nd \\
\hline $1 \mathrm{~S}-3$ & 1.75 & 1.97 & $8.70 \mathrm{E}-01$ & na & na & na & na \\
\hline $1 \mathrm{~S}-4$ & 1.92 & 2.15 & 8.99E-01 & $2.67 \mathrm{E}-02$ & nd & nd & $2.05 \mathrm{E}-03$ \\
\hline $1 \mathrm{~S}-5$ & 2.08 & 2.33 & $9.97 \mathrm{E}-01$ & na & na & na & na \\
\hline $1 \mathrm{~S}-6$ & 2.25 & 2.51 & na & $2.59 \mathrm{E}-02$ & nd & nd & $8.64 \mathrm{E}-03$ \\
\hline $1 \mathrm{~S}-8$ & 2.58 & 2.87 & $1.06 \mathrm{E}+00$ & na & na & na & na \\
\hline $1 \mathrm{~S}-11$ & 3.08 & 3.41 & $1.06 \mathrm{E}+00$ & $2.68 \mathrm{E}-02$ & nd & nd & $6.86 \mathrm{E}-02$ \\
\hline $1 \mathrm{~S}-14$ & 3.58 & 3.94 & $1.07 \mathrm{E}+00$ & $2.71 \mathrm{E}-02$ & nd & nd & $1.32 \mathrm{E}-01$ \\
\hline $1 \mathrm{~S}-17$ & 4.08 & 4.48 & $1.06 \mathrm{E}+00$ & na & na & na & na \\
\hline $1 \mathrm{~S}-23$ & 5.08 & 5.56 & $1.05 \mathrm{E}+00$ & na & na & na & na \\
\hline $1 \mathrm{~S}-40$ & 12.42 & 13.98 & na & 2.39E-02 & nd & nd & 8.87E-01 \\
\hline $1 \mathrm{~S}-48$ & 21.75 & 24.02 & na & $2.45 \mathrm{E}-02$ & nd & nd & $9.98 \mathrm{E}-01$ \\
\hline $1 \mathrm{~S}-56$ & 31.08 & 34.05 & na & $2.44 \mathrm{E}-02$ & nd & nd & $1.01 \mathrm{E}+00$ \\
\hline $1 \mathrm{~S}-64$ & 40.42 & 44.09 & na & $2.55 \mathrm{E}-02$ & nd & nd & $9.81 \mathrm{E}-01$ \\
\hline $1 \mathrm{~S}-72$ & 49.75 & 54.12 & na & $2.50 \mathrm{E}-02$ & nd & nd & $1.04 \mathrm{E}+00$ \\
\hline $1 \mathrm{~S}-80$ & 59.08 & 64.16 & na & $2.52 \mathrm{E}-02$ & nd & nd & $1.05 \mathrm{E}+00$ \\
\hline $1 \mathrm{~S}-88$ & 68.42 & 74.20 & na & $2.46 \mathrm{E}-02$ & nd & nd & $1.02 \mathrm{E}+00$ \\
\hline $1 \mathrm{~S}-96$ & 77.75 & 84.23 & na & $2.42 \mathrm{E}-02$ & nd & nd & $1.01 \mathrm{E}+00$ \\
\hline 1D-1 & 80.09 & 86.74 & $1.37 \mathrm{E}+00$ & $1.46 \mathrm{E}-02$ & nd & nd & $6.02 \mathrm{E}-01$ \\
\hline 1D-2 & 80.67 & 88.00 & $1.11 \mathrm{E}-01$ & $2.41 \mathrm{E}-02$ & nd & nd & $9.96 \mathrm{E}-01$ \\
\hline $1 \mathrm{D}-3$ & 90.84 & 89.25 & $3.52 \mathrm{E}-02$ & na & na & na & na \\
\hline $1 \mathrm{D}-4$ & 92.00 & 90.51 & na & $2.36 \mathrm{E}-02$ & nd & nd & $6.55 \mathrm{E}-01$ \\
\hline $1 \mathrm{D}-5$ & 93.17 & 91.76 & $1.23 \mathrm{E}-02$ & na & na & na & na \\
\hline $1 \mathrm{D}-6$ & 94.34 & 93.02 & na & 2.39E-02 & nd & nd & $4.18 \mathrm{E}-01$ \\
\hline $1 \mathrm{D}-7$ & 95.50 & 94.27 & $9.47 \mathrm{E}-03$ & na & na & na & na \\
\hline $1 \mathrm{D}-8$ & 96.67 & 95.53 & na & $2.37 \mathrm{E}-02$ & nd & nd & $2.89 \mathrm{E}-01$ \\
\hline 1D-9 & 97.84 & 96.78 & $6.85 \mathrm{E}-03$ & na & na & na & na \\
\hline 1D-11 & 100.17 & 99.29 & $5.98 \mathrm{E}-03$ & $2.47 \mathrm{E}-02$ & nd & nd & $1.71 \mathrm{E}-01$ \\
\hline 1D-14 & 103.67 & 103.05 & na & $2.42 \mathrm{E}-02$ & nd & nd & $1.14 \mathrm{E}-01$ \\
\hline 1D-16 & 106.00 & 105.56 & na & $2.58 \mathrm{E}-02$ & nd & nd & $9.68 \mathrm{E}-02$ \\
\hline $1 \mathrm{D}-24$ & 115.34 & 115.60 & na & $2.85 \mathrm{E}-02$ & nd & nd & 4.97E-02 \\
\hline $1 \mathrm{D}-32$ & 124.67 & 125.64 & na & $3.14 \mathrm{E}-02$ & nd & nd & $2.84 \mathrm{E}-02$ \\
\hline 1D-40 & 134.00 & 135.67 & na & $3.91 \mathrm{E}-02$ & nd & nd & $2.02 \mathrm{E}-02$ \\
\hline 1D-48 & 143.34 & 145.71 & na & 4.79E-02 & nd & nd & $1.54 \mathrm{E}-02$ \\
\hline
\end{tabular}


Table A-1, cont.

\begin{tabular}{cccccccc}
\hline Sample\# & $\begin{array}{c}\text { Accumulated run } \\
\text { time (hrs) }\end{array}$ & $\begin{array}{c}\text { Column } \\
\text { pore } \\
\text { volumes }\end{array}$ & $\begin{array}{c}\text { C/Co } \\
\text { Iodide }\end{array}$ & $\begin{array}{c}\text { C/Co } \\
\text { Strontium }\end{array}$ & $\begin{array}{c}\text { C/Co } \\
\text { Cesium }\end{array}$ & $\begin{array}{c}\text { C/Co } \\
\text { Samarium }\end{array}$ & $\begin{array}{c}\text { C/Co } \\
\text { Uranium }\end{array}$ \\
\hline 1D-56 & 152.67 & 155.74 & na & $6.40 \mathrm{E}-02$ & nd & nd & $1.18 \mathrm{E}-02$ \\
1D-64 & 163.66 & 165.78 & na & $8.06 \mathrm{E}-02$ & nd & nd & $1.05 \mathrm{E}-02$ \\
1D-72 & 172.99 & 175.82 & na & $9.67 \mathrm{E}-02$ & nd & nd & $7.94 \mathrm{E}-03$ \\
1D-80 & 182.32 & 185.85 & na & $1.19 \mathrm{E}-01$ & nd & nd & $6.91 \mathrm{E}-03$ \\
1D-88 & 191.02 & 195.21 & na & $1.47 \mathrm{E}-01$ & nd & nd & $5.89 \mathrm{E}-03$ \\
1D-96 & 200.36 & 205.24 & na & $1.66 \mathrm{E}-01$ & nd & nd & $5.12 \mathrm{E}-03$ \\
1D-104 & 209.69 & 215.28 & na & $1.87 \mathrm{E}-01$ & nd & nd & $4.35 \mathrm{E}-03$ \\
1D-112 & 219.02 & 225.32 & na & $2.04 \mathrm{E}-01$ & nd & nd & $3.84 \mathrm{E}-03$ \\
1D-120 & 228.36 & 235.35 & na & $2.20 \mathrm{E}-01$ & nd & nd & $3.59 \mathrm{E}-03$ \\
1D-128 & 237.69 & 245.39 & na & $2.26 \mathrm{E}-01$ & nd & nd & $3.33 \mathrm{E}-03$ \\
1D-136 & 247.02 & 255.43 & na & $2.34 \mathrm{E}-01$ & nd & nd & $3.07 \mathrm{E}-03$ \\
1D-144 & 256.02 & 264.75 & na & $2.39 \mathrm{E}-01$ & nd & nd & $2.56 \mathrm{E}-03$ \\
1D-152 & 265.22 & 274.78 & na & $2.48 \mathrm{E}-01$ & nd & nd & $2.30 \mathrm{E}-03$ \\
1D-160 & 274.55 & 284.82 & na & $2.49 \mathrm{E}-01$ & nd & nd & $1.79 \mathrm{E}-03$ \\
1D-168 & 283.89 & 294.85 & na & $2.41 \mathrm{E}-01$ & nd & nd & $2.30 \mathrm{E}-03$ \\
1D-176 & 293.22 & 304.89 & na & $2.40 \mathrm{E}-01$ & nd & nd & $1.54 \mathrm{E}-03$ \\
1D-184 & 302.55 & 314.93 & na & $2.32 \mathrm{E}-01$ & nd & nd & $1.54 \mathrm{E}-03$ \\
1D-192 & 311.89 & 324.96 & na & $2.21 \mathrm{E}-01$ & nd & nd & $1.54 \mathrm{E}-03$ \\
1D-200 & 221.22 & 335.00 & na & $2.16 \mathrm{E}-01$ & nd & nd & $1.54 \mathrm{E}-03$ \\
1D-208 & 330.29 & 344.55 & na & $2.11 \mathrm{E}-01$ & nd & nd & $1.02 \mathrm{E}-03$ \\
1D-216 & 339.62 & 354.59 & na & $2.03 \mathrm{E}-01$ & $2.67 \mathrm{E}-04$ & nd & $1.02 \mathrm{E}-03$ \\
\hline
\end{tabular}


Table A-2. Flow-through Experiment \#2 data.

UGTA Reactive-Transport Column Experiment \#2 using alluvium U-1A

Column "B" Dimension (IDxL):0.9906cm x 14.907cm

$\begin{array}{ll}\text { Alluvium mass }(\mathrm{g}) & 16.01 \\ \text { Alluvium volume }(\mathrm{mL}) & 6.16 \\ \text { Column volume }(\mathrm{mL}) & 11.49 \\ \text { Column pore volume }(\mathrm{mL}) & 5.33 \\ \text { Porosity }(\%) & 46.39 \\ \text { Pore volume }(\mathrm{mL}) & 6.73\end{array}$

\begin{tabular}{|c|c|c|c|c|c|c|c|}
\hline Sample\# & $\begin{array}{l}\text { Accumulated run } \\
\text { time (hrs) }\end{array}$ & $\begin{array}{c}\text { Column } \\
\text { pore } \\
\text { volumes }\end{array}$ & $\begin{array}{l}\mathrm{C} / \mathrm{Co} \\
\text { Iodide }\end{array}$ & $\begin{array}{c}\mathrm{C} / \mathrm{Co} \\
\text { Strontium }\end{array}$ & $\begin{array}{c}\mathrm{C} / \mathrm{Co} \\
\text { Cesium }\end{array}$ & $\begin{array}{c}\mathrm{C} / \mathrm{Co} \\
\text { Samarium }\end{array}$ & $\begin{array}{c}\mathrm{C} / \mathrm{Co} \\
\text { Neptunium }\end{array}$ \\
\hline $2 \mathrm{~S}-1$ & 0.17 & 0.19 & $9.57 \mathrm{E}-04$ & $2.54 \mathrm{E}-02$ & $2.48 \mathrm{E}-02$ & $1.12 \mathrm{E}-03$ & nd \\
\hline $2 \mathrm{~S}-2$ & 0.25 & 0.39 & $1.32 \mathrm{E}-03$ & na & na & na & na \\
\hline $2 \mathrm{~S}-3$ & 0.42 & 0.58 & $2.05 \mathrm{E}-03$ & na & na & na & na \\
\hline $2 \mathrm{~S}-4$ & 0.58 & 0.77 & $1.50 \mathrm{E}-01$ & na & na & na & na \\
\hline $2 \mathrm{~S}-5$ & 0.75 & 0.97 & $4.25 \mathrm{E}-01$ & na & na & na & na \\
\hline $2 S-6$ & 0.92 & 1.16 & $6.52 \mathrm{E}-01$ & na & na & na & na \\
\hline $2 \mathrm{~S}-7$ & 1.08 & 1.35 & $7.88 \mathrm{E}-01$ & na & na & na & na \\
\hline $2 \mathrm{~S}-8$ & 1.25 & 1.55 & $8.27 \mathrm{E}-01$ & na & na & na & na \\
\hline $2 \mathrm{~S}-9$ & 1.42 & 1.74 & 8.68E-01 & na & na & na & na \\
\hline $2 \mathrm{~S}-10$ & 1.58 & 1.93 & 8.98E-01 & $2.43 \mathrm{E}-02$ & nd & nd & nd \\
\hline $2 \mathrm{~S}-11$ & 1.75 & 2.12 & $9.48 \mathrm{E}-01$ & na & na & na & na \\
\hline $2 S-15$ & 2.42 & 2.90 & $9.66 \mathrm{E}-01$ & na & na & na & na \\
\hline $2 \mathrm{~S}-20$ & 3.25 & 3.86 & $1.00 \mathrm{E}+00$ & $2.80 \mathrm{E}-02$ & nd & nd & nd \\
\hline $2 \mathrm{~S}-25$ & 4.08 & 4.83 & $9.52 \mathrm{E}-01$ & na & na & na & na \\
\hline $2 \mathrm{~S}-30$ & 4.92 & 5.79 & $1.01 \mathrm{E}+00$ & $3.23 \mathrm{E}-02$ & nd & nd & nd \\
\hline $2 \mathrm{~S}-31$ & 5.45 & 6.84 & $9.95 \mathrm{E}-01$ & na & na & na & na \\
\hline $2 \mathrm{~S}-40$ & 13.55 & 16.22 & na & 4.19E-02 & nd & nd & $3.50 \mathrm{E}-02$ \\
\hline $2 \mathrm{~S}-50$ & 22.55 & 26.65 & na & $4.00 \mathrm{E}-02$ & $2.05 \mathrm{E}-03$ & $1.98 \mathrm{E}-04$ & $3.07 \mathrm{E}-01$ \\
\hline $2 \mathrm{~S}-60$ & 31.55 & 37.08 & na & $3.88 \mathrm{E}-02$ & nd & nd & 4.86E-01 \\
\hline $2 \mathrm{~S}-70$ & 40.55 & 47.51 & na & $4.66 \mathrm{E}-02$ & nd & nd & $6.13 \mathrm{E}-01$ \\
\hline $2 \mathrm{~S}-80$ & 49.55 & 57.94 & na & $6.58 \mathrm{E}-02$ & $5.26 \mathrm{E}-04$ & nd & $6.89 \mathrm{E}-01$ \\
\hline 2D-1 & 50.38 & 58.67 & $7.83 \mathrm{E}-01$ & 7.10E-02 & nd & nd & 7.57E-01 \\
\hline $2 \mathrm{D}-2$ & 50.46 & 58.92 & 8.08E-01 & na & na & na & na \\
\hline $2 \mathrm{D}-3$ & 50.63 & 59.16 & 8.51E-01 & na & na & na & na \\
\hline $2 \mathrm{D}-4$ & 50.79 & 59.41 & $5.76 \mathrm{E}-01$ & na & na & na & na \\
\hline $2 \mathrm{D}-5$ & 50.96 & 59.65 & $3.03 \mathrm{E}-01$ & na & na & na & na \\
\hline $2 \mathrm{D}-6$ & 51.13 & 59.89 & $1.67 \mathrm{E}-01$ & na & na & na & na \\
\hline $2 \mathrm{D}-7$ & 51.29 & 60.14 & $9.75 \mathrm{E}-02$ & na & na & na & na \\
\hline $2 \mathrm{D}-8$ & 51.46 & 60.38 & 8.30E-02 & na & na & na & na \\
\hline $2 \mathrm{D}-9$ & 51.63 & 60.63 & $9.02 \mathrm{E}-02$ & na & na & na & na \\
\hline 2D-10 & 51.79 & 60.87 & $4.55 \mathrm{E}-02$ & $6.96 \mathrm{E}-02$ & nd & nd & 7.93E-01 \\
\hline 2D-11 & 51.96 & 61.11 & $3.35 \mathrm{E}-02$ & na & na & na & na \\
\hline 2D-12 & 52.13 & 61.36 & $2.58 \mathrm{E}-02$ & na & na & na & na \\
\hline $2 \mathrm{D}-14$ & 52.46 & 61.84 & $1.54 \mathrm{E}-02$ & na & na & na & na \\
\hline 2D-18 & 53.13 & 62.82 & $6.81 \mathrm{E}-03$ & na & na & na & na \\
\hline
\end{tabular}


Table A-2, cont.

\begin{tabular}{|c|c|c|c|c|c|c|c|}
\hline Sample\# & $\begin{array}{l}\text { Accumulated run } \\
\text { time (hrs) }\end{array}$ & $\begin{array}{l}\text { Column } \\
\text { pore } \\
\text { volumes }\end{array}$ & $\begin{array}{l}\mathrm{C} / \mathrm{Co} \\
\text { Iodide }\end{array}$ & $\begin{array}{c}\mathrm{C} / \mathrm{Co} \\
\text { Strontium }\end{array}$ & $\begin{array}{l}\mathrm{C} / \mathrm{Co} \\
\text { Cesium }\end{array}$ & $\begin{array}{c}\text { C/Co } \\
\text { Samarium }\end{array}$ & $\begin{array}{c}\text { C/Co } \\
\text { Neptunium }\end{array}$ \\
\hline $2 \mathrm{D}-20$ & 53.46 & 63.31 & na & $2.06 \mathrm{E}-02$ & $6.29 \mathrm{E}-04$ & nd & $6.43 \mathrm{E}-01$ \\
\hline 2D-30 & 60.63 & 74.33 & na & $7.54 \mathrm{E}-02$ & nd & nd & 4.01E-01 \\
\hline 2D-40 & 69.63 & 87.50 & na & 9.04E-02 & nd & nd & $2.55 \mathrm{E}-01$ \\
\hline 2D-50 & 78.63 & 100.68 & na & 1.09E-01 & nd & nd & $1.87 \mathrm{E}-01$ \\
\hline 2D-60 & 87.63 & 113.85 & na & $1.28 \mathrm{E}-01$ & nd & nd & 1.49E-01 \\
\hline 2D-70 & 96.63 & 127.02 & na & $1.53 \mathrm{E}-01$ & nd & nd & $1.31 \mathrm{E}-01$ \\
\hline $2 \mathrm{D}-80$ & 105.63 & 140.19 & na & $1.70 \mathrm{E}-01$ & nd & nd & $1.00 \mathrm{E}-01$ \\
\hline 2D-90 & 114.63 & 153.36 & na & $1.87 \mathrm{E}-01$ & nd & nd & $9.14 \mathrm{E}-02$ \\
\hline 2D-100 & 123.63 & 166.53 & na & $2.10 \mathrm{E}-01$ & nd & nd & 7.83E-02 \\
\hline $2 \mathrm{D}-110$ & 132.63 & 179.71 & na & 2.03E-01 & nd & nd & 7.16E-02 \\
\hline $2 \mathrm{D}-120$ & 141.63 & 192.88 & na & $2.26 \mathrm{E}-01$ & nd & nd & $6.53 \mathrm{E}-02$ \\
\hline 2D-130 & 150.63 & 206.05 & na & $2.12 \mathrm{E}-01$ & nd & nd & $5.83 \mathrm{E}-02$ \\
\hline $2 \mathrm{D}-140$ & 159.63 & 219.22 & na & 1.99E-01 & nd & nd & $5.61 \mathrm{E}-02$ \\
\hline 2D-150 & 168.63 & 232.39 & na & 1.92E-01 & nd & nd & $5.07 \mathrm{E}-02$ \\
\hline 2D-160 & 177.63 & 245.56 & na & $1.85 \mathrm{E}-01$ & $8.10 \mathrm{E}-04$ & nd & 4.47E-02 \\
\hline 2D-170 & 186.63 & 258.74 & na & 1.79E-01 & $4.95 \mathrm{E}-03$ & nd & 4.23E-02 \\
\hline 2D-180 & 195.63 & 271.91 & na & 1.69E-01 & $1.05 \mathrm{E}-02$ & nd & 4.17E-02 \\
\hline 2D-190 & 204.63 & 285.08 & na & 1.59E-01 & $1.72 \mathrm{E}-02$ & nd & 4.06E-02 \\
\hline 2D-200 & 213.63 & 298.25 & na & $1.50 \mathrm{E}-01$ & $2.54 \mathrm{E}-02$ & nd & $3.62 \mathrm{E}-02$ \\
\hline 2D-210 & 222.31 & 310.96 & na & $1.51 \mathrm{E}-01$ & $3.35 \mathrm{E}-02$ & nd & $3.69 \mathrm{E}-02$ \\
\hline $2 \mathrm{D}-220$ & 231.31 & 324.13 & na & $1.44 \mathrm{E}-01$ & $4.08 \mathrm{E}-02$ & nd & $3.23 \mathrm{E}-02$ \\
\hline 2D-230 & 240.31 & 337.30 & na & $1.36 \mathrm{E}-01$ & 4.74E-02 & nd & $3.05 \mathrm{E}-02$ \\
\hline $2 \mathrm{D}-240$ & 249.31 & 350.47 & na & $1.29 \mathrm{E}-01$ & $5.12 \mathrm{E}-02$ & nd & $2.98 \mathrm{E}-02$ \\
\hline $2 \mathrm{D}-250$ & 258.31 & 363.64 & na & $1.22 \mathrm{E}-01$ & $5.57 \mathrm{E}-02$ & nd & $2.70 \mathrm{E}-02$ \\
\hline 2D-260 & 267.31 & 376.82 & na & 1.14E-01 & $6.11 \mathrm{E}-02$ & nd & $2.85 \mathrm{E}-02$ \\
\hline 2D-270 & 276.31 & 389.99 & na & 1.09E-01 & $5.92 \mathrm{E}-02$ & nd & $2.52 \mathrm{E}-02$ \\
\hline 2D-278 & 283.51 & 400.52 & na & $1.04 \mathrm{E}-01$ & $6.38 \mathrm{E}-02$ & nd & $2.35 \mathrm{E}-02$ \\
\hline
\end{tabular}


Table A-3 Flow-through Experiment \#3 data.

UGTA Reactive-Transport Column Experiment \#3 using alluvium UE5N 1140'+1160'

Column "C" Dimension (IDxL):0.9906 cm x 14.872cm

\begin{tabular}{|c|c|c|c|c|c|c|c|}
\hline Alluvium 1 & ass (g) & 18.26 & & & & & \\
\hline Alluvium & lume (mL) & 7.13 & & & & & \\
\hline Column vo & Ime $(\mathrm{mL})$ & 11.46 & & & & & \\
\hline Column pc & volume (mL) & 4.33 & & & & & \\
\hline Porosity ( & & 37.76 & & & & & \\
\hline Pore volun & $(\mathrm{mL})$ & 5.73 & & & & & \\
\hline Sample\# & $\begin{array}{l}\text { Accumulated run } \\
\text { time (hrs) }\end{array}$ & $\begin{array}{l}\text { Column } \\
\text { pore } \\
\text { volumes }\end{array}$ & $\begin{array}{l}\mathrm{C} / \mathrm{Co} \\
\text { Iodide }\end{array}$ & $\begin{array}{c}\mathrm{C} / \mathrm{Co} \\
\text { Strontium }\end{array}$ & $\begin{array}{c}\mathrm{C} / \mathrm{Co} \\
\text { Cesium }\end{array}$ & $\begin{array}{c}\mathrm{C} / \mathrm{Co} \\
\text { Samarium }\end{array}$ & $\begin{array}{c}\mathrm{C} / \mathrm{Co} \\
\text { Uranium }\end{array}$ \\
\hline $3 \mathrm{~S}-1$ & 0.20 & 0.33 & $6.46 \mathrm{E}-04$ & $1.31 \mathrm{E}-03$ & $1.25 \mathrm{E}-03$ & nd & nd \\
\hline $3 \mathrm{~S}-2$ & 0.30 & 0.66 & $2.28 \mathrm{E}-03$ & na & na & na & na \\
\hline $3 S-3$ & 0.50 & 0.99 & $6.94 \mathrm{E}-02$ & na & na & na & na \\
\hline $3 \mathrm{~S}-4$ & 0.70 & 1.33 & $3.15 \mathrm{E}-01$ & na & na & na & na \\
\hline $3 S-5$ & 0.90 & 1.66 & $5.11 \mathrm{E}-01$ & na & na & na & na \\
\hline $3 S-6$ & 1.10 & 1.99 & $6.69 \mathrm{E}-01$ & $1.31 \mathrm{E}-03$ & nd & nd & $2.72 \mathrm{E}-01$ \\
\hline $3 \mathrm{~S}-7$ & 1.30 & 2.32 & $8.24 \mathrm{E}-01$ & na & na & na & na \\
\hline $3 S-8$ & 1.50 & 2.65 & 8.89E-01 & na & na & na & na \\
\hline $3 S-9$ & 1.70 & 2.98 & $9.40 \mathrm{E}-01$ & na & na & na & na \\
\hline $3 \mathrm{~S}-10$ & 1.90 & 3.32 & $9.27 \mathrm{E}-01$ & na & na & na & na \\
\hline $3 \mathrm{~S}-11$ & 2.10 & 3.65 & $9.53 \mathrm{E}-01$ & $1.34 \mathrm{E}-03$ & nd & nd & $5.33 \mathrm{E}-01$ \\
\hline $3 S-13$ & 2.50 & 4.31 & na & $1.35 \mathrm{E}-03$ & nd & nd & $6.14 \mathrm{E}-01$ \\
\hline $3 \mathrm{~S}-15$ & 2.90 & 4.97 & $9.46 \mathrm{E}-01$ & $1.32 \mathrm{E}-03$ & nd & nd & $6.45 \mathrm{E}-01$ \\
\hline $3 \mathrm{~S}-17$ & 3.66 & 6.82 & na & $1.33 \mathrm{E}-03$ & nd & nd & $7.22 \mathrm{E}-01$ \\
\hline $3 S-19$ & 5.49 & 9.86 & na & $1.49 \mathrm{E}-03$ & nd & nd & $8.05 \mathrm{E}-01$ \\
\hline $3 \mathrm{~S}-20$ & 6.41 & 11.38 & $9.40 \mathrm{E}-01$ & na & na & na & na \\
\hline $3 \mathrm{~S}-21$ & 7.33 & 12.90 & na & $1.31 \mathrm{E}-03$ & nd & nd & $8.41 \mathrm{E}-01$ \\
\hline $3 \mathrm{~S}-25$ & 10.99 & 18.98 & $9.40 \mathrm{E}-01$ & na & na & na & na \\
\hline $3 \mathrm{~S}-30$ & 15.58 & 26.58 & $9.46 \mathrm{E}-01$ & 1.34E-03 & nd & nd & $9.32 \mathrm{E}-01$ \\
\hline $3 \mathrm{~S}-40$ & 24.74 & 41.78 & na & $1.49 \mathrm{E}-03$ & nd & nd & $9.75 \mathrm{E}-01$ \\
\hline $3 \mathrm{~S}-50$ & 33.91 & 56.98 & na & $1.41 \mathrm{E}-03$ & nd & nd & $9.62 \mathrm{E}-01$ \\
\hline $3 \mathrm{~S}-60$ & 43.08 & 72.17 & na & $1.42 \mathrm{E}-03$ & nd & nd & $9.76 \mathrm{E}-01$ \\
\hline $3 \mathrm{~S}-70$ & 52.24 & 87.37 & na & $1.56 \mathrm{E}-03$ & nd & nd & $9.59 \mathrm{E}-01$ \\
\hline $3 \mathrm{~S}-80$ & 61.41 & 102.57 & na & $1.58 \mathrm{E}-03$ & nd & nd & $9.83 \mathrm{E}-01$ \\
\hline $3 \mathrm{~S}-90$ & 70.58 & 117.77 & na & $1.74 \mathrm{E}-03$ & nd & nd & $9.64 \mathrm{E}-01$ \\
\hline $3 \mathrm{D}-1$ & 71.51 & 119.01 & $1.01 \mathrm{E}+00$ & $1.76 \mathrm{E}-03$ & nd & $2.66 \mathrm{E}-04$ & $9.72 \mathrm{E}-01$ \\
\hline $3 \mathrm{D}-2$ & 71.61 & 119.34 & $9.00 \mathrm{E}-01$ & na & na & na & na \\
\hline $3 \mathrm{D}-3$ & 71.81 & 119.67 & $6.78 \mathrm{E}-01$ & na & na & na & na \\
\hline $3 \mathrm{D}-4$ & 72.01 & 120.01 & $3.51 \mathrm{E}-01$ & na & na & na & na \\
\hline $3 \mathrm{D}-5$ & 72.21 & 120.34 & $1.52 \mathrm{E}-01$ & na & na & na & na \\
\hline $3 \mathrm{D}-6$ & 72.41 & 120.67 & $5.08 \mathrm{E}-02$ & $1.88 \mathrm{E}-03$ & nd & nd & $9.44 \mathrm{E}-01$ \\
\hline $3 \mathrm{D}-7$ & 72.61 & 121.00 & $1.91 \mathrm{E}-02$ & na & na & na & na \\
\hline $3 \mathrm{D}-8$ & 72.81 & 121.33 & $5.72 \mathrm{E}-03$ & na & na & na & na \\
\hline $3 \mathrm{D}-9$ & 73.01 & 121.66 & $2.26 \mathrm{E}-03$ & na & na & na & na \\
\hline $3 \mathrm{D}-10$ & 73.21 & 122.00 & $8.57 \mathrm{E}-04$ & na & na & na & na \\
\hline
\end{tabular}


Table A-3, cont.

\begin{tabular}{|c|c|c|c|c|c|c|c|}
\hline Sample\# & $\begin{array}{l}\text { Accumulated run } \\
\text { time (hrs) }\end{array}$ & $\begin{array}{l}\text { Column } \\
\text { pore } \\
\text { volumes }\end{array}$ & $\begin{array}{l}\mathrm{C} / \mathrm{Co} \\
\text { Iodide }\end{array}$ & $\begin{array}{c}\mathrm{C} / \mathrm{Co} \\
\text { Strontium }\end{array}$ & $\begin{array}{l}\mathrm{C} / \mathrm{Co} \\
\text { Cesium }\end{array}$ & $\begin{array}{c}\text { C/Co } \\
\text { Samarium }\end{array}$ & $\begin{array}{c}\mathrm{C} / \mathrm{Co} \\
\text { Uranium }\end{array}$ \\
\hline $3 \mathrm{D}-11$ & 73.41 & 122.33 & $4.72 \mathrm{E}-04$ & $1.96 \mathrm{E}-03$ & nd & nd & $6.29 \mathrm{E}-01$ \\
\hline $3 \mathrm{D}-12$ & 73.61 & 122.66 & $2.87 \mathrm{E}-04$ & na & na & na & na \\
\hline $3 \mathrm{D}-15$ & 74.21 & 123.65 & $2.35 \mathrm{E}-04$ & na & na & na & na \\
\hline $3 \mathrm{D}-16$ & 74.41 & 123.99 & na & $1.98 \mathrm{E}-03$ & nd & nd & $4.29 \mathrm{E}-01$ \\
\hline $3 \mathrm{D}-20$ & 75.21 & 125.31 & $1.23 \mathrm{E}-04$ & na & na & na & na \\
\hline $3 \mathrm{D}-21$ & 75.41 & 125.64 & na & $2.02 \mathrm{E}-03$ & nd & nd & $3.14 \mathrm{E}-01$ \\
\hline $3 \mathrm{D}-25$ & 75.41 & 126.97 & $1.02 \mathrm{E}-04$ & na & na & na & na \\
\hline $3 \mathrm{D}-26$ & 76.21 & 127.30 & na & $1.98 \mathrm{E}-03$ & nd & nd & $2.50 \mathrm{E}-01$ \\
\hline $3 \mathrm{D}-30$ & 76.41 & 128.63 & $7.43 \mathrm{E}-05$ & na & na & na & na \\
\hline 3D-31 & 77.41 & 128.96 & na & $2.07 \mathrm{E}-03$ & nd & nd & $2.03 \mathrm{E}-01$ \\
\hline $3 \mathrm{D}-36$ & 78.21 & 130.62 & na & $2.03 \mathrm{E}-03$ & nd & nd & $1.67 \mathrm{E}-01$ \\
\hline $3 \mathrm{D}-41$ & 81.92 & 137.03 & na & $2.12 \mathrm{E}-03$ & nd & nd & $1.01 \mathrm{E}-01$ \\
\hline $3 \mathrm{D}-50$ & 89.25 & 150.70 & na & $2.75 \mathrm{E}-03$ & nd & nd & $4.48 \mathrm{E}-02$ \\
\hline $3 \mathrm{D}-60$ & 99.34 & 165.90 & na & $3.76 \mathrm{E}-03$ & nd & nd & $2.66 \mathrm{E}-02$ \\
\hline $3 \mathrm{D}-70$ & 108.50 & 181.10 & na & $5.05 \mathrm{E}-03$ & nd & nd & $1.83 \mathrm{E}-02$ \\
\hline $3 \mathrm{D}-80$ & 117.67 & 196.30 & na & $6.55 \mathrm{E}-03$ & nd & nd & $1.29 \mathrm{E}-02$ \\
\hline $3 \mathrm{D}-90$ & 126.84 & 211.49 & na & 7.79E-03 & nd & nd & $1.09 \mathrm{E}-02$ \\
\hline 3D-100 & 136.00 & 226.69 & na & $8.96 \mathrm{E}-03$ & nd & nd & $7.80 \mathrm{E}-03$ \\
\hline $3 \mathrm{D}-110$ & 144.98 & 241.25 & na & $1.00 \mathrm{E}-02$ & nd & nd & $6.86 \mathrm{E}-03$ \\
\hline 3D-120 & 153.95 & 256.45 & na & $1.17 \mathrm{E}-02$ & nd & nd & $6.05 \mathrm{E}-03$ \\
\hline 3D-130 & 163.12 & 271.65 & na & $1.30 \mathrm{E}-02$ & nd & nd & $4.74 \mathrm{E}-03$ \\
\hline $3 \mathrm{D}-140$ & 172.29 & 286.85 & na & $1.33 \mathrm{E}-02$ & nd & nd & $4.12 \mathrm{E}-03$ \\
\hline $3 \mathrm{D}-150$ & 181.45 & 302.04 & na & $1.43 \mathrm{E}-02$ & nd & nd & $3.37 \mathrm{E}-03$ \\
\hline $3 \mathrm{D}-160$ & 190.62 & 317.24 & na & $1.51 \mathrm{E}-02$ & nd & nd & $2.99 \mathrm{E}-03$ \\
\hline $3 \mathrm{D}-170$ & 199.79 & 332.44 & na & $1.48 \mathrm{E}-02$ & nd & nd & $2.74 \mathrm{E}-03$ \\
\hline 3D-180 & 208.95 & 347.63 & na & $1.57 \mathrm{E}-02$ & nd & nd & $2.12 \mathrm{E}-03$ \\
\hline 3D-190 & 218.12 & 362.83 & na & $1.61 \mathrm{E}-02$ & nd & nd & $1.93 \mathrm{E}-03$ \\
\hline $3 \mathrm{D}-200$ & 227.29 & 378.03 & na & $1.67 \mathrm{E}-02$ & nd & nd & $1.68 \mathrm{E}-03$ \\
\hline $3 \mathrm{D}-210$ & 236.45 & 393.23 & na & $1.70 \mathrm{E}-02$ & nd & nd & $1.43 \mathrm{E}-03$ \\
\hline $3 \mathrm{D}-220$ & 245.62 & 408.42 & na & $1.62 \mathrm{E}-02$ & nd & nd & $1.37 \mathrm{E}-03$ \\
\hline $3 \mathrm{D}-230$ & 254.79 & 423.62 & na & $1.71 \mathrm{E}-02$ & nd & nd & $1.18 \mathrm{E}-03$ \\
\hline 3D-239 & 263.04 & 437.30 & na & $1.72 \mathrm{E}-02$ & nd & nd & $8.11 \mathrm{E}-04$ \\
\hline
\end{tabular}


Table A-4 Flow-through Experiment \#4 data.

UGTA Reactive-Transport Column Experiment \#4 using alluvium UE5N 1140'+1160'

Column "D" Dimension (IDxL): $0.9906 \mathrm{~cm}$ x $14.899 \mathrm{~cm}$

\begin{tabular}{|c|c|c|c|c|c|c|c|}
\hline \multicolumn{2}{|c|}{ Alluvium mass (g) } & \multicolumn{6}{|l|}{15.32} \\
\hline \multicolumn{2}{|c|}{ Alluvium volume (mL) } & 5.98 & & & & & \\
\hline \multicolumn{2}{|c|}{ Column volume (mL) } & 11.48 & & & & & \\
\hline \multicolumn{2}{|c|}{ Column pore volume $(\mathrm{mL})$} & 5.50 & & & & & \\
\hline \multicolumn{2}{|c|}{ Porosity (\%) } & 47.89 & & & & & \\
\hline \multicolumn{2}{|c|}{ Pore volume $(\mathrm{mL})$} & 6.90 & & & & & \\
\hline Sample\# & $\begin{array}{l}\text { Accumulated run } \\
\text { time (hrs) }\end{array}$ & $\begin{array}{l}\text { Column } \\
\text { pore } \\
\text { volumes }\end{array}$ & $\begin{array}{l}\mathrm{C} / \mathrm{Co} \\
\text { Iodide }\end{array}$ & $\begin{array}{c}\mathrm{C} / \mathrm{Co} \\
\text { Strontium }\end{array}$ & $\begin{array}{l}\mathrm{C} / \mathrm{Co} \\
\text { Cesium }\end{array}$ & $\begin{array}{c}\mathrm{C} / \mathrm{Co} \\
\text { Samarium }\end{array}$ & $\begin{array}{c}\text { C/Co } \\
\text { Neptunium }\end{array}$ \\
\hline $4 \mathrm{~S}-1$ & 0.20 & 0.27 & na & $8.47 \mathrm{E}-04$ & nd & $3.23 \mathrm{E}-03$ & nd \\
\hline $4 \mathrm{~S}-2$ & 0.30 & 0.55 & $1.79 \mathrm{E}-02$ & na & na & na & na \\
\hline $4 \mathrm{~S}-3$ & 0.50 & 0.82 & $1.67 \mathrm{E}-01$ & na & na & na & na \\
\hline $4 S-4$ & 0.70 & 1.10 & $4.41 \mathrm{E}-01$ & na & na & na & na \\
\hline $4 S-5$ & 0.90 & 1.37 & $5.79 \mathrm{E}-01$ & na & na & na & na \\
\hline $4 S-6$ & 1.10 & 1.65 & $8.14 \mathrm{E}-01$ & na & na & na & na \\
\hline $4 S-7$ & 1.30 & 1.92 & $8.22 \mathrm{E}-01$ & na & na & na & na \\
\hline $4 S-8$ & 1.50 & 2.20 & $8.80 \mathrm{E}-01$ & na & na & na & na \\
\hline $4 S-9$ & 1.70 & 2.47 & $8.89 \mathrm{E}-01$ & na & na & na & na \\
\hline $4 S-10$ & 1.90 & 2.75 & na & $5.47 \mathrm{E}-04$ & nd & nd & $7.53 \mathrm{E}-05$ \\
\hline $4 \mathrm{~S}-11$ & 2.10 & 3.02 & $9.06 \mathrm{E}-01$ & na & na & na & na \\
\hline $4 S-12$ & 2.30 & 3.30 & $9.15 \mathrm{E}-01$ & na & na & na & na \\
\hline $4 S-13$ & 2.50 & 3.57 & $9.11 \mathrm{E}-01$ & na & na & na & na \\
\hline $4 S-14$ & 2.70 & 3.85 & $9.02 \mathrm{E}-01$ & na & na & na & na \\
\hline $4 S-15$ & 2.90 & 4.12 & $9.06 \mathrm{E}-01$ & na & na & na & na \\
\hline $4 S-19$ & 5.49 & 8.18 & $9.24 \mathrm{E}-01$ & na & na & na & na \\
\hline $4 \mathrm{~S}-20$ & 6.41 & 9.44 & na & $8.06 \mathrm{E}-04$ & nd & $6.47 \mathrm{E}-03$ & $3.08 \mathrm{E}-01$ \\
\hline $4 S-29$ & 14.66 & 20.78 & $9.33 \mathrm{E}-01$ & na & na & na & na \\
\hline $4 \mathrm{~S}-30$ & 15.58 & 22.04 & na & $9.19 \mathrm{E}-04$ & nd & 5.39E-03 & $7.35 \mathrm{E}-01$ \\
\hline $4 S-39$ & 23.83 & 33.39 & 8.97E-01 & na & na & na & na \\
\hline $4 \mathrm{~S}-40$ & 24.74 & 34.65 & na & $1.21 \mathrm{E}-03$ & nd & $6.47 \mathrm{E}-03$ & 8.99E-01 \\
\hline $4 \mathrm{~S}-45$ & 29.33 & 40.95 & na & $1.51 \mathrm{E}-03$ & nd & $7.54 \mathrm{E}-03$ & $9.20 \mathrm{E}-01$ \\
\hline $4 \mathrm{~S}-50$ & 33.91 & 47.25 & na & 8.88E-04 & nd & $4.31 \mathrm{E}-03$ & $9.52 \mathrm{E}-01$ \\
\hline $4 S-55$ & 38.49 & 53.55 & na & $1.08 \mathrm{E}-03$ & nd & 5.39E-03 & $9.56 \mathrm{E}-01$ \\
\hline $4 S-60$ & 43.08 & 59.85 & na & $9.61 \mathrm{E}-04$ & nd & nd & $9.53 \mathrm{E}-01$ \\
\hline $4 \mathrm{~S}-65$ & 47.66 & 66.15 & na & $9.61 \mathrm{E}-04$ & nd & nd & $9.56 \mathrm{E}-01$ \\
\hline $4 S-70$ & 52.24 & 72.46 & na & $8.57 \mathrm{E}-04$ & nd & nd & $9.58 \mathrm{E}-01$ \\
\hline $4 \mathrm{~S}-73$ & 54.90 & 75.98 & na & $9.92 \mathrm{E}-04$ & nd & $3.23 \mathrm{E}-03$ & $9.66 \mathrm{E}-01$ \\
\hline 4D-1 & 55.15 & 76.32 & $9.36 \mathrm{E}-01$ & $1.47 \mathrm{E}-03$ & nd & $6.47 \mathrm{E}-03$ & $9.91 \mathrm{E}-01$ \\
\hline $4 \mathrm{D}-2$ & 55.15 & 76.67 & $9.15 \mathrm{E}-01$ & na & na & na & na \\
\hline $4 \mathrm{D}-3$ & 55.15 & 77.01 & $7.82 \mathrm{E}-01$ & na & na & na & na \\
\hline $4 \mathrm{D}-4$ & 55.15 & 77.35 & 4.13E-01 & na & na & na & na \\
\hline $4 D-5$ & 55.15 & 77.70 & $1.58 \mathrm{E}-01$ & na & na & na & na \\
\hline $4 \mathrm{D}-6$ & 55.15 & 78.04 & $5.98 \mathrm{E}-02$ & na & na & na & na \\
\hline 4D-7 & 55.15 & 78.39 & $2.37 \mathrm{E}-02$ & na & na & na & na \\
\hline
\end{tabular}


Table A-4, cont.

\begin{tabular}{|c|c|c|c|c|c|c|c|}
\hline Sample\# & $\begin{array}{l}\text { Accumulated run } \\
\text { time (hrs) }\end{array}$ & $\begin{array}{c}\text { Pore } \\
\text { volumes }\end{array}$ & $\begin{array}{l}\mathrm{C} / \mathrm{Co} \\
\text { Iodide }\end{array}$ & $\begin{array}{c}\mathrm{C} / \mathrm{Co} \\
\text { Strontium }\end{array}$ & $\begin{array}{l}\mathrm{C} / \mathrm{Co} \\
\text { Cesium }\end{array}$ & $\begin{array}{c}\mathrm{C} / \mathrm{Co} \\
\text { Samarium }\end{array}$ & $\begin{array}{c}\mathrm{C} / \mathrm{Co} \\
\text { Neptunium }\end{array}$ \\
\hline 4D-8 & 55.15 & 78.73 & $1.09 \mathrm{E}-02$ & na & na & na & na \\
\hline 4D-9 & 55.15 & 79.07 & $5.66 \mathrm{E}-03$ & na & na & na & na \\
\hline 4D-10 & 57.28 & 79.42 & na & $1.51 \mathrm{E}-03$ & nd & nd & $8.24 \mathrm{E}-01$ \\
\hline 4D-11 & 55.15 & 79.76 & $3.87 \mathrm{E}-03$ & na & na & na & na \\
\hline $4 \mathrm{D}-20$ & 59.78 & 82.85 & na & $1.58 \mathrm{E}-03$ & nd & nd & $5.01 \mathrm{E}-01$ \\
\hline $4 \mathrm{D}-21$ & 55.15 & 83.20 & $2.90 \mathrm{E}-03$ & na & na & na & na \\
\hline $4 \mathrm{D}-25$ & 61.03 & 84.57 & na & $1.67 \mathrm{E}-03$ & nd & nd & $4.05 \mathrm{E}-01$ \\
\hline $4 \mathrm{D}-30$ & 62.28 & 86.29 & na & $1.64 \mathrm{E}-03$ & nd & nd & $3.43 \mathrm{E}-01$ \\
\hline $4 \mathrm{D}-35$ & 63.53 & 88.01 & na & $1.57 \mathrm{E}-03$ & nd & nd & $2.85 \mathrm{E}-01$ \\
\hline $4 \mathrm{D}-40$ & 64.78 & 89.73 & na & $1.66 \mathrm{E}-03$ & nd & nd & $2.49 \mathrm{E}-01$ \\
\hline $4 \mathrm{D}-50$ & 67.28 & 93.17 & na & $1.67 \mathrm{E}-03$ & nd & nd & $2.07 \mathrm{E}-01$ \\
\hline $4 \mathrm{D}-60$ & 70.78 & 98.44 & na & $1.62 \mathrm{E}-03$ & nd & nd & $1.52 \mathrm{E}-01$ \\
\hline $4 \mathrm{D}-70$ & 79.94 & 111.04 & na & $2.17 \mathrm{E}-03$ & nd & nd & $9.11 \mathrm{E}-02$ \\
\hline $4 \mathrm{D}-80$ & 89.11 & 123.64 & na & $2.96 \mathrm{E}-03$ & nd & nd & $6.32 \mathrm{E}-02$ \\
\hline 4D-90 & 98.28 & 136.25 & na & $3.05 \mathrm{E}-03$ & nd & nd & $4.50 \mathrm{E}-02$ \\
\hline 4D-100 & 107.44 & 148.85 & na & $3.15 \mathrm{E}-03$ & nd & nd & $3.67 \mathrm{E}-02$ \\
\hline 4D-110 & 116.42 & 160.92 & na & $3.42 \mathrm{E}-03$ & nd & nd & 2.99E-02 \\
\hline 4D-120 & 125.39 & 173.53 & na & $3.85 \mathrm{E}-03$ & nd & nd & 2.49E-02 \\
\hline 4D-130 & 134.56 & 186.13 & na & $5.37 \mathrm{E}-04$ & nd & nd & $2.01 \mathrm{E}-02$ \\
\hline 4D-140 & 143.39 & 198.28 & na & $3.98 \mathrm{E}-03$ & nd & nd & $1.81 \mathrm{E}-02$ \\
\hline 4D-150 & 152.56 & 210.88 & na & $3.68 \mathrm{E}-03$ & nd & nd & $1.48 \mathrm{E}-02$ \\
\hline $4 \mathrm{D}-160$ & 161.73 & 223.48 & na & $3.53 \mathrm{E}-03$ & nd & nd & $1.43 \mathrm{E}-02$ \\
\hline $4 \mathrm{D}-170$ & 170.89 & 236.08 & na & $3.63 \mathrm{E}-03$ & nd & nd & $1.27 \mathrm{E}-02$ \\
\hline 4D-180 & 180.06 & 248.69 & na & $3.70 \mathrm{E}-03$ & nd & nd & $1.01 \mathrm{E}-02$ \\
\hline 4D-190 & 189.23 & 261.29 & na & $3.77 \mathrm{E}-03$ & nd & nd & $9.25 \mathrm{E}-03$ \\
\hline 4D-200 & 198.39 & 273.89 & na & $4.27 \mathrm{E}-03$ & nd & nd & $8.10 \mathrm{E}-03$ \\
\hline 4D-210 & 207.56 & 286.50 & na & $4.14 \mathrm{E}-03$ & nd & nd & $8.21 \mathrm{E}-03$ \\
\hline $4 \mathrm{D}-220$ & 216.73 & 299.10 & na & $4.55 \mathrm{E}-03$ & nd & nd & $6.20 \mathrm{E}-03$ \\
\hline $4 \mathrm{D}-230$ & 225.89 & 311.70 & na & $4.66 \mathrm{E}-03$ & nd & nd & $5.85 \mathrm{E}-03$ \\
\hline $4 D-240$ & 235.06 & 324.31 & na & $4.64 \mathrm{E}-03$ & nd & nd & 4.95E-03 \\
\hline $4 D-250$ & 244.23 & 336.91 & na & $4.71 \mathrm{E}-03$ & nd & nd & $5.05 \mathrm{E}-03$ \\
\hline $4 \mathrm{D}-260$ & 253.39 & 349.51 & na & $4.56 \mathrm{E}-03$ & nd & nd & $4.30 \mathrm{E}-03$ \\
\hline 4D-265 & 257.98 & 355.81 & na & $4.53 \mathrm{E}-03$ & nd & nd & $4.23 \mathrm{E}-03$ \\
\hline $4 D-273$ & 265.31 & 365.90 & na & $4.80 \mathrm{E}-03$ & nd & nd & $3.12 \mathrm{E}-03$ \\
\hline
\end{tabular}




\section{Appendix B. Quantitative X-ray Diffraction Data}

\section{Los Alamos}

NATIONAL LABORATORY

\section{memorandum}

Hydrology, Geochemistry, and Geology (EES-6)
To/MS: $\quad$ Rick Warren, EES-6, D469

From/MS: Steve J. Chipera, EES-6, D469

Phone/Fax:7-1110/5-3285

E-mail: chipera@lanl.gov

Date: $\quad$ August $30^{\text {th }}, 2001$

\section{Subject: QXRD Results for the Miscellaneous High-Priority Samples}

Hi Rick,

Attached are the QXRD results for the samples that you wanted me to expedite. It appears that I ran them a while back but had not gotten to the data analysis. Hope this gives you what you desire!

As per your Request for format of QXRD results email of 01-MAR-2001, I will use the "Alternatively, a simple statement in the letter of transmittal will suffice that all the above minerals are reported if above detection limits" clause.

Therefore, calcite, cristobalite, feldspar, glass, hematite, mica, opal-CT, quartz, smectite, tridymite, analcime, clinoptilolite, and mordenite are all reported if above detection limits (as are all other minerals). If not reported, they were not observed to be present in the samples.

Table B.1 QXRD Analysis

\begin{tabular}{|c|c|c|c|c|c|c|c|c|c|c|c|c|c|c|c|c|}
\hline Sample & $\begin{array}{c}\text { Smect } \\
\text { ite }\end{array}$ & $\begin{array}{l}\begin{array}{l}\text { Clinop- } \\
\text { tilolite }\end{array} \\
\end{array}$ & $\begin{array}{c}\text { Kaolin } \\
\text { ite }\end{array}$ & $\begin{array}{l}\text { Chlor- } \\
\text { ite? }\end{array}$ & $\begin{array}{l}\text { Tridy- } \\
\text { mite }\end{array}$ & $\begin{array}{l}\text { Cristo } \\
\text { balite }\end{array}$ & Quartz & K-Spar & $\begin{array}{l}\text { Plagio } \\
\text { clase }\end{array}$ & Glass & $\begin{array}{l}\text { Hem- } \\
\text { atite }\end{array}$ & Biotite & $\begin{array}{c}\text { Horn- } \\
\text { blende }\end{array}$ & $\begin{array}{l}\text { Cal- } \\
\text { cite }\end{array}$ & $\begin{array}{c}\text { Dol- } \\
\text { omite }\end{array}$ & Total \\
\hline UE5N-1140 S(2 & 14.2 & 24.3 & --- & --- & --- & 2.2 & 8.5 & 11.3 & 34.3 & --- & 0.3 & 4.4 & 0.6 & 2.6 & --- & 102.6 \\
\hline UE5N-1160 S(2 & 9.4 & 15.8 & --- & --- & --- & 1.0 & 8.3 & 9.0 & 32.9 & 18.1 & 0.3 & 2.2 & 0.7 & 2.6 & --- & 100.3 \\
\hline U1A/102C/V2(b & 28.9 & 1.2 & 3.8 & 0.1 & --- & --- & 16.9 & 4.2 & 8.9 & 10.7 & --- & 3.2 & 0.4 & 17.5 & 0.5 & 96.4 \\
\hline TH030801/1(C & --- & 2.4 & --- & --- & 2.7 & 1.2 & 4.1 & 9.0 & 14.5 & 67.5 & 0.4 & 1.9 & 0.1 & --- & --- & 103.7 \\
\hline TH030801/2(C & --- & 2.1 & --- & --- & 1.9 & 1.9 & 4.9 & 7.4 & 18.4 & 62.9 & 0.8 & 1.6 & 0.1 & --- & --- & 102.1 \\
\hline TH030801/3(C & --- & --- & --- & --- & --- & 15.5 & 10.9 & 37.0 & 31.7 & --- & 0.9 & 3.9 & --- & --- & --- & 99.9 \\
\hline TH030801/6(C & --- & --- & --- & --- & --- & 2.8 & 29.8 & 36.3 & 29.9 & --- & 0.6 & 3.4 & --- & --- & --- & 102.9 \\
\hline
\end{tabular}

Call me if you have any questions.

$\mathrm{SJC}: \mathrm{sjc}$ 
Table B.2 QXRD Analysis

\begin{tabular}{|c|c|c|c|c|c|c|c|c|}
\hline \multicolumn{3}{|c|}{ UE5N-1140 S(2 } & \multicolumn{3}{|c|}{ UE5N-1160 S(2 } & \multicolumn{3}{|c|}{ U1A/102C/V2(b } \\
\hline Phase & Amount & $\begin{array}{c}\text { Normalized } \\
\text { to } 100 \%\end{array}$ & Phase & Amount & $\begin{array}{c}\text { Normalized } \\
\text { to } 100 \%\end{array}$ & Phase & Amount & $\begin{array}{r}\text { Normalized } \\
\text { to } 100 \%\end{array}$ \\
\hline Quartz & 8.5 & 8.3 & Clinoptilolite & 15.8 & 15.7 & Quartz & 16.9 & 17.5 \\
\hline Clinoptilolite & 24.3 & 23.7 & Quartz & 8.3 & 8.3 & Calcite & 17.5 & 18.2 \\
\hline Sanidine & 2.9 & 2.8 & Sanidine & 2.4 & 2.4 & Sanidine & 1.1 & 1.1 \\
\hline Orthoclase & 8.4 & 8.2 & Orthoclase & 6.6 & 6.6 & Orthoclase & 3.1 & 3.2 \\
\hline Bytownite & 29.9 & 29.1 & Bytownite & 30.9 & 30.8 & Bytownite & 8.9 & 9.3 \\
\hline Albite & 4.4 & 4.3 & Albite & 2.0 & 2.0 & Kaolinite & 3.8 & 4.0 \\
\hline \multirow[t]{2}{*}{ Smectite } & 14.2 & 13.8 & Smectite & 9.4 & 9.4 & Smectite & 28.9 & 30.0 \\
\hline & 0.0 & 0.0 & Glass & 18.1 & 18.1 & Glass & 10.7 & 11.1 \\
\hline Biotite & 4.4 & 4.3 & Biotite & 2.2 & 2.2 & Biotite & 3.2 & 3.4 \\
\hline Calcite & 2.6 & 2.5 & Calcite & 2.6 & 2.6 & Chlorite & 0.1 & 0.1 \\
\hline Hornblende & 0.6 & 0.5 & Hornblende & 0.7 & 0.7 & Hornblende & 0.4 & 0.4 \\
\hline Cristobalite & 2.2 & 2.2 & Cristobalite & 1.0 & 1.0 & Clinoptilolite & 1.2 & 1.3 \\
\hline \multirow[t]{3}{*}{ Hematite } & 0.3 & 0.3 & Hematite & 0.3 & 0.3 & Dolomite & 0.5 & 0.5 \\
\hline & 0.0 & 0.0 & & 0.0 & 0.0 & & 0.0 & 0.0 \\
\hline & 0.0 & 0.0 & & 0.0 & 0.0 & & 0.0 & 0.0 \\
\hline Total & 102.6 & 100 & Total & 100.3 & 100 & Total & 96.4 & 100 \\
\hline \multicolumn{2}{|c|}{ TH030801/1(C } & & \multicolumn{2}{|c|}{ TH030801/2(C } & & \multicolumn{2}{|c|}{ TH030801/3(C } & \\
\hline Phase & Amount & $\begin{array}{r}\text { Normalized } \\
\text { to } 100 \%\end{array}$ & Phase & Amount & $\begin{array}{c}\text { Normalized } \\
\text { to } 100 \%\end{array}$ & Phase & Amount & $\begin{array}{r}\text { Normalized } \\
\text { to } 100 \%\end{array}$ \\
\hline Glass & 67.5 & 65.1 & Glass & 62.9 & 61.6 & Quartz & 10.9 & 10.9 \\
\hline Quartz & 4.1 & 3.9 & Quartz & 4.9 & 4.8 & Cristobalite & 15.5 & 15.5 \\
\hline Sanidine & 3.4 & 3.3 & Sanidine & 3.2 & 3.1 & Sanidine & 22.2 & 22.2 \\
\hline Orthoclase & 5.5 & 5.3 & Orthoclase & 4.3 & 4.2 & Orthoclase & 14.8 & 14.8 \\
\hline Bytownite & 9.1 & 8.8 & Bytownite & 13.2 & 12.9 & Bytownite & 21.4 & 21.4 \\
\hline \multirow[t]{2}{*}{ Albite } & 5.3 & 5.1 & Albite & 5.2 & 5.1 & Albite & 10.3 & 10.3 \\
\hline & 0.0 & 0.0 & & 0.0 & 0.0 & Biotite & 3.9 & 3.9 \\
\hline Clinoptilolite & 2.4 & 2.3 & Clinoptilolite & 2.1 & 2.1 & Hematite & 0.9 & 0.9 \\
\hline Biotite & 1.9 & 1.8 & Biotite & 1.6 & 1.5 & & 0.0 & 0.0 \\
\hline Hematite & 0.4 & 0.4 & Hematite & 0.8 & 0.8 & & 0.0 & 0.0 \\
\hline Cristobalite & 1.2 & 1.1 & Cristobalite & 1.9 & 1.9 & & 0.0 & 0.0 \\
\hline Tridymite & 2.7 & 2.6 & Tridymite & 1.9 & 1.9 & & 0.0 & 0.0 \\
\hline \multirow[t]{3}{*}{ Hornblende } & 0.1 & 0.1 & Hornblende & 0.1 & 0.1 & & 0.0 & 0.0 \\
\hline & 0.0 & 0.0 & & 0.0 & 0.0 & & 0.0 & 0.0 \\
\hline & 0.0 & 0.0 & & 0.0 & 0.0 & & 0.0 & 0.0 \\
\hline Total & 103.7 & 100 & Total & 102.1 & 100 & Total & 99.9 & 100 \\
\hline \multicolumn{9}{|c|}{ TH030801/6(C } \\
\hline Phase & Amount & $\begin{array}{r}\text { Normalized } \\
\text { to } 100 \%\end{array}$ & & & & & & \\
\hline Quartz & 29.8 & 29.0 & & & & & & \\
\hline Cristobalite & 2.8 & 2.7 & & & & & & \\
\hline Sanidine & 17.0 & 16.5 & & & & & & \\
\hline Orthoclase & 19.4 & 18.8 & & & & & & \\
\hline Bytownite & 18.8 & 18.2 & & & & & & \\
\hline Albite & 11.1 & 10.8 & & & & & & \\
\hline Biotite & 3.4 & 3.4 & & & & & & \\
\hline \multirow[t]{8}{*}{ Hematite } & 0.6 & 0.6 & & & & & & \\
\hline & 0.0 & 0.0 & & & & & & \\
\hline & 0.0 & 0.0 & & & & & & \\
\hline & 0.0 & 0.0 & & & & & & \\
\hline & 0.0 & 0.0 & & & & & & \\
\hline & 0.0 & 0.0 & & & & & & \\
\hline & 0.0 & 0.0 & & & & & & \\
\hline & 0.0 & 0.0 & & & & & & \\
\hline Total & 102.9 & 100 & & & & & & \\
\hline
\end{tabular}




\section{Appendix C. Characterization Data for U-1a Alluvium}

The following tables contain the various data collected for samples U-1a.102C.V1 to V5. A description of the sampling location, petrology, and other data can be found in Rose et al. (1999).

Table C-1. Coarse particle size determination of U-1a.102C.V1 to V5 samples.

\begin{tabular}{lcccc}
\hline Sample & $\begin{array}{c}> \\
\end{array}$ & ---- g, air dry ---- & mass $\% \dagger$ & $\begin{array}{c}<1 \mathrm{~mm} \\
\text { mass } \% \text { oven dry }\end{array}$ \\
\hline V1 & 1912 & 1024 & 3.4 & 34 \\
V2 & $0 *$ & $1862 *$ & 8.0 & $100^{*}$ \\
V3 & 1651 & 998 & 3.2 & 37 \\
V4 & 469 & 1111 & 3.3 & 70 \\
V5 & 1875 & 420 & 3.8 & 18 \\
\hline
\end{tabular}

* sample V2 was highly cemented and required significant crushing to disaggregate grains; result may overestimate the $<1 \mathrm{~mm}$ fraction.

$\dagger$ mass $\%=100 \times$ (air dry-oven dry)/oven dry. Water content measured for air dry

$<1 \mathrm{~mm}$ fraction.

Table C-2. Elemental analysis of saturation paste extracts ${ }^{\dagger}$ of U1A.102C.V1 to V5 alluvium samples.

\begin{tabular}{|c|c|c|c|c|c|c|c|c|c|c|}
\hline Sample & $\mathrm{pH}$ & $\mathrm{Na}$ & $\mathrm{Mg}$ & $\bar{K}$ & $\mathrm{Ca}$ & $\mathrm{Sr}$ & Cs & $\mathrm{Sm}$ & $\mathrm{Eu}$ & $\mathrm{U}$ \\
\hline 102C.V1 & 8.47 & $9.15 \mathrm{E}-4$ & $2.16 \mathrm{E}-4$ & $1.47 \mathrm{E}-4$ & $2.91 \mathrm{E}-4$ & $1.61 \mathrm{E}-6$ & $1.1 \mathrm{E}-9$ & $-t$ & $5.8 \mathrm{E}-11$ & $1.7 \mathrm{E}-9$ \\
\hline 102C.V2 & 8.54 & $1.01 \mathrm{E}-3$ & $2.47 \mathrm{E}-4$ & $1.70 \mathrm{E}-4$ & 3.57E-4 & $1.92 \mathrm{E}-6$ & $6.0 \mathrm{E}-10$ & - & 3.4E-11 & $3.0 \mathrm{E}-9$ \\
\hline 102C.V3 & 8.45 & $9.13 \mathrm{E}-4$ & $2.04 \mathrm{E}-4$ & $1.52 \mathrm{E}-4$ & 2.89E-4 & $1.49 \mathrm{E}-6$ & $8.0 \mathrm{E}-10$ & - & - & $1.7 \mathrm{E}-9$ \\
\hline 102C.V4 & 8.41 & $9.67 \mathrm{E}-4$ & $2.24 \mathrm{E}-4$ & $1.50 \mathrm{E}-4$ & $3.21 \mathrm{E}-4$ & $1.69 \mathrm{E}-6$ & $3.2 \mathrm{E}-10$ & - & - & $2.8 \mathrm{E}-9$ \\
\hline 102C.V5 & 8.49 & $1.57 \mathrm{E}-3$ & $1.65 \mathrm{E}-4$ & $1.51 \mathrm{E}-4$ & $2.28 \mathrm{E}-4$ & $1.23 \mathrm{E}-6$ & $4.2 \mathrm{E}-10$ & $1.7 \mathrm{E}-10$ & $3.5 \mathrm{E}-11$ & $1.8 \mathrm{E}-9$ \\
\hline
\end{tabular}

$\dagger$ Approximate saturation paste with saturation estimated at $50 \%$ porosity and $2.65 \mathrm{~g} / \mathrm{cm}^{3}$ rock density. \pm not detected.

I $\mathrm{RSD}<3 \%$ for $\mathrm{Na}, \mathrm{Mg}, \mathrm{K}, \mathrm{Ca}$, and $\mathrm{Sr} ;<10 \%$ for $\mathrm{Cs} ;<50 \%$ for $\mathrm{Sm}$ and $\mathrm{Eu} ;<15 \%$ for $\mathrm{U}$. $\S \mathrm{Cl}^{-}, \mathrm{NO}_{3}{ }^{-}$, and $\mathrm{SO}_{4}{ }^{2-}$ concentrations in these samples were approximately 3.6E-4, 2.2E-5, and 7.7E-5 $\mathrm{mol} / \mathrm{L}$, respectively. 


\section{Appendix D. Batch Sorption Data.}

Table D-1. Data for strontium (10 mg/L) sorption to U-1a alluvium

\begin{tabular}{|c|c|c|c|c|c|c|c|c|c|}
\hline \multirow{2}{*}{$\begin{array}{l}\text { Sample } \\
\text { Name }\end{array}$} & \multirow{2}{*}{$\begin{array}{l}\text { Solid } \\
\text { Conc. } \\
\mathrm{g} / \mathrm{mL}\end{array}$} & \multirow{2}{*}{$\begin{array}{c}\mathrm{Sr} \\
\text { Added } \\
\mathrm{mol} / \mathrm{l}\end{array}$} & \multirow{2}{*}{$\begin{array}{l}\text { Sorption } \\
\text { Time } \\
\text { days }\end{array}$} & \multirow{2}{*}{$\begin{array}{c}\text { Final } \\
\mathrm{pH}\end{array}$} & \multicolumn{5}{|c|}{------------- Final Concentration --------------- } \\
\hline & & & & & $\mathrm{Sr}$ & $\mathrm{Na}$ & $\begin{array}{r}\mathrm{Mg} \\
\mathrm{nol} / \mathrm{L}\end{array}$ & $\mathrm{K}$ & $\mathrm{Ca}$ \\
\hline $50 \mathrm{I} \mathrm{Sr}$ & 0.049 & $1.11 \mathrm{E}-4$ & 2 & 7.51 & $2.36 \mathrm{E}-4$ & $8.57 \mathrm{E}-4$ & $2.59 \mathrm{E}-3$ & 7.80E-4 & $3.74 \mathrm{E}-2$ \\
\hline $75 \mathrm{I} \mathrm{Sr}$ & 050 & $11 \mathrm{E}-4$ & 2 & 7.72 & $45 \mathrm{E}-4$ & $7.56 \mathrm{E}-4$ & $1.77 \mathrm{E}-3$ & $5.02 \mathrm{E}-4$ & $1.22 \mathrm{E}-2$ \\
\hline $00 \mathrm{I} \mathrm{Sr}$ & 18 & $1 \mathrm{E}-4$ & 2 & 8.00 & -5 & 35E-4 & -3 & -4 & $1.72 \mathrm{E}-3$ \\
\hline $25 \mathrm{I} \mathrm{Sr}$ & 050 & $11 \mathrm{E}-4$ & 2 & 8.23 & $9 \mathrm{E}-5$ & $15 \mathrm{E}-3$ & $5.40 \mathrm{E}-4$ & $3.13 \mathrm{E}-4$ & $7.75 \mathrm{E}-4$ \\
\hline $50 \mathrm{I} \mathrm{Sr}$ & 049 & $11 \mathrm{E}-4$ & 2 & 8.26 & $2.07 \mathrm{E}-5$ & $1.81 \mathrm{E}-3$ & $3.05 \mathrm{E}-4$ & $2.82 \mathrm{E}-4$ & $4.20 \mathrm{E}-4$ \\
\hline $75 \mathrm{I} \mathrm{Sr}$ & 0.050 & $11 \mathrm{E}-4$ & 2 & 8.37 & $1.37 \mathrm{E}-5$ & $3.08 \mathrm{E}-3$ & $1.92 \mathrm{E}-4$ & $3.00 \mathrm{E}-4$ & $2.55 \mathrm{E}-4$ \\
\hline $00 \mathrm{I} \mathrm{Sr}$ & 0.049 & $10 \mathrm{E}-4$ & 2 & 8.56 & $35 \mathrm{E}-6$ & $4.82 \mathrm{E}-3$ & $1.21 \mathrm{E}-4$ & $2.38 \mathrm{E}-4$ & $1.43 \mathrm{E}-4$ \\
\hline $25 \mathrm{I} \mathrm{Sr}$ & 050 & $10 \mathrm{E}-4$ & 2 & 8.86 & $92 \mathrm{E}-6$ & $6.86 \mathrm{E}-3$ & $8.04 \mathrm{E}-5$ & $2.42 \mathrm{E}-4$ & $8.49 \mathrm{E}-5$ \\
\hline $50 \mathrm{I} \mathrm{Sr}$ & 048 & 08E-4 & 6 & 9.42 & $15 \mathrm{E}-6$ & $1.75 \mathrm{E}-2$ & $6.90 \mathrm{E}-5$ & $3.48 \mathrm{E}-4$ & $3.25 \mathrm{E}-5$ \\
\hline $50 \mathrm{II} \mathrm{Sr}$ & 0.048 & $1.10 \mathrm{E}-4$ & 2 & 7.53 & $1.60 \mathrm{E}-4$ & $8.02 \mathrm{E}-4$ & $2.57 \mathrm{E}-3$ & $6.10 \mathrm{E}-4$ & $3.49 \mathrm{E}-2$ \\
\hline $75 \mathrm{II} \mathrm{Sr}$ & 0.049 & $1.10 \mathrm{E}-4$ & 2 & 7.79 & -4 & $7.86 \mathrm{E}-4$ & $1.82 \mathrm{E}-3$ & 4.55E-4 & $9.04 \mathrm{E}-3$ \\
\hline $00 \mathrm{II} \mathrm{Sr}$ & 050 & $0 \mathrm{E}-4$ & 2 & 8.07 & & $9.31 \mathrm{E}-4$ & $1.03 \mathrm{E}-3$ & 3.4 & $2.42 \mathrm{E}-3$ \\
\hline $25 \mathrm{II} \mathrm{Sr}$ & 049 & 11E-4 & 2 & 8.28 & & $1.26 \mathrm{E}-3$ & $5.49 \mathrm{E}-4$ & 3.27 & $8.42 \mathrm{E}-4$ \\
\hline $50 \mathrm{II} \mathrm{Sr}$ & 0.049 & $1.11 \mathrm{E}-4$ & 2 & 8.32 & & $1.93 \mathrm{E}-3$ & $3.13 \mathrm{E}-4$ & $2.99 \mathrm{E}-4$ & $4.94 \mathrm{E}-4$ \\
\hline 75 II Sr & 50 & $10 \mathrm{E}-4$ & 2 & 8.45 & & $3.41 \mathrm{E}-3$ & 3E-4 & $3.05 \mathrm{E}-4$ & $3.16 \mathrm{E}-4$ \\
\hline $00 \mathrm{II} \mathrm{Sr}$ & 0.048 & $1.10 \mathrm{E}-4$ & 2 & 8.67 & & $5.11 \mathrm{E}-3$ & E-4 & 2.26 & $4.18 \mathrm{E}-4$ \\
\hline $25 \mathrm{II} \mathrm{Sr}$ & 048 & $10 \mathrm{E}-4$ & 2 & 8.90 & & $7.27 \mathrm{E}-3$ & $5 E-5$ & 2.0 & $6.77 \mathrm{E}-5$ \\
\hline $50 \mathrm{II} \mathrm{Sr}$ & 0.048 & $1.08 \mathrm{E}-4$ & 6 & 9.43 & & $1.68 \mathrm{E}-2$ & E-5 & $2.99 \mathrm{E}-4$ & $3.46 \mathrm{E}-5$ \\
\hline 50 III IN & 0.0 & - & - & - & & $7.96 \mathrm{E}-4$ & $3.31 \mathrm{E}-3$ & 5.34E-4 & $3.56 \mathrm{E}-2$ \\
\hline $75 \mathrm{III} \mathrm{I}$ & 0. & - & - & 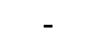 & & E-4 & E-3 & 4.3 & $9.93 \mathrm{E}-3$ \\
\hline $00 \mathrm{I}$ & 0 & - & - & - & & E-4 & E-3 & 3.1 & $2.41 \mathrm{E}-3$ \\
\hline $25 \mathrm{I}$ & & - & - & - & & -3 & -4 & 2.33 & 8.04E-4 \\
\hline $50 \mathrm{Il}$ & 0 & - & - & - & & $9 \mathrm{E}-3$ & E-4 & $1.69 \mathrm{E}-4$ & $6.16 \mathrm{E}-4$ \\
\hline $75 \mathrm{III} \mathrm{II}$ & 0 & - & - & - & & E-3 & E-4 & 1.8 & $2.46 \mathrm{E}-4$ \\
\hline $00 \mathrm{I}$ & & - & - & - & & E-3 & E-4 & 1.7 & $1.30 \mathrm{E}-4$ \\
\hline $25 \mathrm{I}$ & 0.050 & - & - & - & & $6.89 \mathrm{E}-3$ & $8.58 \mathrm{E}-5$ & $2.15 \mathrm{E}-4$ & $1.05 \mathrm{E}-4$ \\
\hline $50 \mathrm{IIl}$ & 0.049 & - & - & - & & $1.74 \mathrm{E}-2$ & $1.24 \mathrm{E}-4$ & 2.01E-4 & $5.44 \mathrm{E}-5$ \\
\hline $50 \mathrm{III}$ IN & - & $1.11 \mathrm{E}-4$ & 2 & 7.51 & & E-4 & 3.29E-3 & 6.2 & 4.39E-2 \\
\hline .75 III INIT Sr & - & $1.11 \mathrm{E}-4$ & 2 & 7.78 & & $5.29 \mathrm{E}-4$ & $1.98 \mathrm{E}-3$ & $5.85 \mathrm{E}-4$ & $1.06 \mathrm{E}-2$ \\
\hline $.00 \mathrm{III} \mathrm{II}$ & - & $1.11 \mathrm{E}-4$ & 2 & 8.03 & $6 \mathrm{E}-4$ & $9.40 \mathrm{E}-4$ & $1.10 \mathrm{E}-3$ & $2.93 \mathrm{E}-4$ & $2.51 \mathrm{E}-3$ \\
\hline $.25 \mathrm{III} \mathrm{I}$ & - & $1.11 \mathrm{E}-4$ & 2 & 8.27 & 1. & $1.15 \mathrm{E}-3$ & $5.28 \mathrm{E}-4$ & $2.29 \mathrm{E}-4$ & $8.84 \mathrm{E}-4$ \\
\hline $.50 \mathrm{III} \mathrm{IN}$ & - & $1.11 \mathrm{E}-4$ & 2 & 8.43 & & $1.59 \mathrm{E}-3$ & $2.87 \mathrm{E}-4$ & $1.69 \mathrm{E}-4$ & $4.17 \mathrm{E}-4$ \\
\hline $.75 \mathrm{III} \mathrm{IN}$ & - & $1.11 \mathrm{E}-4$ & 2 & 8.66 & $1.27 \mathrm{E}-4$ & $2.82 \mathrm{E}-3$ & $1.76 \mathrm{E}-4$ & $1.71 \mathrm{E}-4$ & $2.44 \mathrm{E}-4$ \\
\hline 00 III IN & - & $1.11 \mathrm{E}-4$ & 2 & 8.83 & $2 \mathrm{E}-4$ & $4.75 \mathrm{E}-3$ & $1.11 \mathrm{E}-4$ & $1.58 \mathrm{E}-4$ & $1.42 \mathrm{E}-4$ \\
\hline & - & IE-4 & 2 & 9. & & $7.17 \mathrm{E}-3$ & $8.97 \mathrm{E}-5$ & $2.25 \mathrm{E}-4$ & $9.97 \mathrm{E}-5$ \\
\hline $.50 \mathrm{III}$ INIT Sr & - & $1.11 \mathrm{E}-4$ & 6 & 9.43 & $8.18 \mathrm{E}-5$ & $1.75 \mathrm{E}-2$ & $9.27 \mathrm{E}-5$ & $2.34 \mathrm{E}-4$ & $3.56 \mathrm{E}-5$ \\
\hline
\end{tabular}


Table D-2. Data for strontium (1 mg/L) sorption to U-1a alluvium.

\begin{tabular}{|c|c|c|c|c|c|c|c|c|c|}
\hline \multirow{3}{*}{$\begin{array}{l}\text { Sample } \\
\text { Name }\end{array}$} & \multirow{3}{*}{$\begin{array}{l}\text { Solid } \\
\text { Conc. } \\
\mathrm{g} / \mathrm{mL}\end{array}$} & \multirow{3}{*}{$\begin{array}{c}\mathrm{Sr} \\
\text { Added } \\
\mathrm{mol} / 1\end{array}$} & \multirow{3}{*}{$\begin{array}{l}\text { Sorption } \\
\text { Time } \\
\text { days }\end{array}$} & \multirow{3}{*}{$\begin{array}{c}\text { Final } \\
\mathrm{pH}\end{array}$} & \multicolumn{5}{|c|}{--------------- Final Concentration -------------- } \\
\hline & & & & & $\mathrm{Sr}$ & $\mathrm{Na}$ & $\mathrm{Mg}$ & K & $\mathrm{Ca}$ \\
\hline & & & & & 620 & $828 \mathrm{~F}-4$ & $315 \mathrm{~F}-3$ & & $54 \mathrm{E}$ \\
\hline $\begin{array}{l}.50 \mathrm{I} \mathrm{Sr} \\
75 \mathrm{ISr}\end{array}$ & 0.050 & $1.01 \mathrm{E}-5$ & 6 & 7.39 & & & & $64 \mathrm{E}-4$ & 3 \\
\hline $75 \mathrm{I} \mathrm{Sr}$ & 050 & $01 \mathrm{E}-5$ & 6 & 7.66 & $.59 \mathrm{E}-5$ & $8.31 \mathrm{E}-4$ & $1.89 \mathrm{E}-3$ & $6.57 \mathrm{E}-4$ & $88 \mathrm{E}-3$ \\
\hline $00 \mathrm{I} \mathrm{Sr}$ & 050 & $1.01 \mathrm{E}-5$ & 6 & 7.95 & $1.77 \mathrm{E}-5$ & $9.75 \mathrm{E}-4$ & $1.08 \mathrm{E}-3$ & 4.57E-4 & $.33 \mathrm{E}-3$ \\
\hline $25 \mathrm{I} \mathrm{Sr}$ & 49 & $02 \mathrm{E}-5$ & 6 & 8.22 & -6 & $28 \mathrm{E}-3$ & $5.29 \mathrm{E}-4$ & $3.88 \mathrm{E}-4$ & 21E-4 \\
\hline $50 \mathrm{I} \mathrm{Sr}$ & 50 & $01 \mathrm{E}-5$ & 6 & 8.35 & 4.61E-6 & $2.01 \mathrm{E}-3$ & $2.79 \mathrm{E}-4$ & $3.63 \mathrm{E}-4$ & $95 \mathrm{E}-4$ \\
\hline $75 \mathrm{I} \mathrm{Sr}$ & 50 & $2 \mathrm{E}-5$ & 6 & 8.50 & 2.96 & 46E-3 & $1.66 \mathrm{E}-4$ & $3.59 \mathrm{E}-4$ & $.23 \mathrm{E}-4$ \\
\hline $00 \mathrm{I} \mathrm{Sr}$ & 050 & $1.01 \mathrm{E}-5$ & 6 & 8.74 & $1.44 \mathrm{E}-6$ & $5.36 \mathrm{E}-3$ & $8.57 \mathrm{E}-5$ & $2.22 \mathrm{E}-4$ & $1.18 \mathrm{E}-4$ \\
\hline $25 \mathrm{I} \mathrm{Sr}$ & 54 & $32 \mathrm{E}-5$ & 6 & 8.91 & & -3 & -5 & -4 & $59 \mathrm{E}-5$ \\
\hline $50 \mathrm{I} \mathrm{Sr}$ & 154 & $2 \mathrm{E}-5$ & 6 & 9.32 & 7 & $.83 \mathrm{E}-2$ & $7.24 \mathrm{E}-5$ & 3.6 & $5.21 \mathrm{E}-5$ \\
\hline $50 \mathrm{II} \mathrm{Sr}$ & 49 & $1 \mathrm{E}-5$ & 6 & 7.44 & $6 .($ & $5 \mathrm{E}-4$ & $3.52 \mathrm{E}-3$ & $6.83 \mathrm{E}-4$ & $3.16 \mathrm{E}-2$ \\
\hline $75 \mathrm{II} \mathrm{Sr}$ & 050 & $1.01 \mathrm{E}-5$ & 6 & 7.70 & $3.44 \mathrm{E}-5$ & $8.40 \mathrm{E}-4$ & $2.12 \mathrm{E}-3$ & $5.42 \mathrm{E}-4$ & $1.04 \mathrm{E}-2$ \\
\hline $00 \mathrm{II} \mathrm{Sr}$ & 50 & $02 \mathrm{E}-5$ & 6 & 7.99 & -5 & $.03 \mathrm{E}-3$ & $1.21 \mathrm{E}-3$ & $4.18 \mathrm{E}-4$ & $2.74 \mathrm{E}-3$ \\
\hline $5 \mathrm{II} \mathrm{Sr}$ & 50 & $01 \mathrm{E}-5$ & 6 & 8.23 & -6 & $17 \mathrm{E}-3$ & $5.78 \mathrm{E}-4$ & $3.16 \mathrm{E}-4$ & $9.25 \mathrm{E}-4$ \\
\hline $50 \mathrm{II} \mathrm{Sr}$ & 050 & $1.02 \mathrm{E}-5$ & 6 & 8.35 & $4.31 \mathrm{E}-6$ & $1.99 \mathrm{E}-3$ & $3.05 \mathrm{E}-4$ & $3.48 \mathrm{E}-4$ & $4.45 \mathrm{E}-4$ \\
\hline $75 \mathrm{II} \mathrm{Sr}$ & 050 & $.02 \mathrm{E}-5$ & 6 & 8.51 & 2.6 & $3.24 \mathrm{E}-3$ & $1.74 \mathrm{E}-4$ & $2.73 \mathrm{E}-4$ & $2.40 \mathrm{E}-4$ \\
\hline $00 \mathrm{II} \mathrm{Sr}$ & 50 & $1.01 \mathrm{E}-5$ & 6 & 8.90 & -6 & $4.98 \mathrm{E}-3$ & $7.75 \mathrm{E}-5$ & $2.24 \mathrm{E}-4$ & $9.40 \mathrm{E}-5$ \\
\hline $25 \mathrm{II} \mathrm{Sr}$ & 551 & $1.27 \mathrm{E}-5$ & 6 & 8.92 & & $9.23 \mathrm{E}-3$ & $5.43 \mathrm{E}-5$ & $2.81 \mathrm{E}-4$ & $5.76 \mathrm{E}-5$ \\
\hline $50 \mathrm{I} \mathrm{Sr}$ & 050 & $18 \mathrm{E}-5$ & 6 & 9.32 & $8.79 \mathrm{E}-7$ & $1.72 \mathrm{E}-2$ & $7.24 \mathrm{E}-5$ & $3.38 \mathrm{E}-4$ & $4.12 \mathrm{E}-5$ \\
\hline $50 \mathrm{I}$ & 551 & - & - & - & 5.2 & $8 \mathrm{E}-4$ & $3.42 \mathrm{E}-3$ & $5.61 \mathrm{E}-4$ & $3.57 \mathrm{E}-2$ \\
\hline $75 \mathrm{III}$ & 50 & - & - & - & $2.80 \mathrm{E}-5$ & $8.17 \mathrm{E}-4$ & $2.02 \mathrm{E}-3$ & $4.31 \mathrm{E}-4$ & $9.60 \mathrm{E}-3$ \\
\hline $00 \mathrm{III}$ & 50 & - & - & - & & E-3 & E-3 & 3.0 & $2.40 \mathrm{E}-3$ \\
\hline $.50 \mathrm{III} \mathrm{II}$ & 051 & - & - & - & 5.6 & $1.23 \mathrm{E}-3$ & $5.63 \mathrm{E}-4$ & $2.47 \mathrm{E}-4$ & $8.38 \mathrm{E}-4$ \\
\hline $25 \mathrm{I}$ & 50 & - & - & - & $3.04 \mathrm{E}-6$ & $1.97 \mathrm{E}-3$ & $2.99 \mathrm{E}-4$ & $1.98 \mathrm{E}-4$ & $4.06 \mathrm{E}-4$ \\
\hline $75 \mathrm{III} \mathrm{I}$ & 050 & - & - & 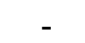 & $1.66 \mathrm{E}-6$ & $3.20 \mathrm{E}-3$ & $1.56 \mathrm{E}-4$ & $1.76 \mathrm{E}-4$ & $1.94 \mathrm{E}-4$ \\
\hline $00 \mathrm{III}$ I & 49 & - & - & - & & E-3 & E-5 & 1.4 & $2.48 \mathrm{E}-4$ \\
\hline $.25 \mathrm{III} \mathrm{I}$ & 050 & 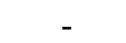 & - & - & & $7.70 \mathrm{E}-3$ & E-5 & $1.69 \mathrm{E}-4$ & $1.37 \mathrm{E}-5$ \\
\hline $.50 \mathrm{III} \mathrm{II}$ & 0.051 & - & - & - & $5.02 \mathrm{E}-7$ & $1.79 \mathrm{E}-2$ & $6.79 \mathrm{E}-5$ & $2.25 \mathrm{E}-4$ & $1.37 \mathrm{E}-5$ \\
\hline $.50 \mathrm{III} \mathrm{I}$ & - & $1.02 \mathrm{E}-5$ & 6 & 7.42 & $6.40 \mathrm{E}-5$ & $8.26 \mathrm{E}-4$ & $3.24 \mathrm{E}-3$ & $6.76 \mathrm{E}-4$ & $3.24 \mathrm{E}-2$ \\
\hline 75 III I & - & $1.02 \mathrm{E}-5$ & 6 & 7.68 & & & E-3 & 5.0 & $1.06 \mathrm{E}-2$ \\
\hline $.00 \mathrm{II}$ & - & $1.02 \mathrm{E}-5$ & 6 & 7.97 & $2.39 \mathrm{E}-5$ & $1.03 \mathrm{E}-3$ & $1.19 \mathrm{E}-3$ & $3.56 \mathrm{E}-4$ & $2.75 \mathrm{E}-3$ \\
\hline $25 \mathrm{III}$ & - & $1.02 \mathrm{E}-5$ & 6 & 8.23 & E-5 & $1.22 \mathrm{E}-3$ & $5.78 \mathrm{E}-4$ & $2.87 \mathrm{E}-4$ & $9.26 \mathrm{E}-4$ \\
\hline $50 \mathrm{II}$ & - & $1.02 \mathrm{E}-5$ & 6 & 8.35 & & E-3 & $3.06 \mathrm{E}-4$ & $2.61 \mathrm{E}-4$ & $4.43 \mathrm{E}-4$ \\
\hline $.75 \mathrm{III} \mathrm{I}$ & - & $1.02 \mathrm{E}-5$ & 6 & 8.51 & E-5 & $3.34 \mathrm{E}-3$ & $1.64 \mathrm{E}-4$ & $2.25 \mathrm{E}-4$ & $2.18 \mathrm{E}-4$ \\
\hline $.00 \mathrm{III} \mathrm{II}$ & - & $1.02 \mathrm{E}-5$ & 6 & 8.82 & $1.35 \mathrm{E}-5$ & $5.37 \mathrm{E}-3$ & $9.30 \mathrm{E}-5$ & $1.98 \mathrm{E}-4$ & $1.06 \mathrm{E}-4$ \\
\hline $25 \mathrm{III} \mathrm{I}$ & - & $1.23 \mathrm{E}-5$ & 6 & 8.92 & $1.38 \mathrm{E}-5$ & $9.57 \mathrm{E}-3$ & $6.33 \mathrm{E}-5$ & $1.97 \mathrm{E}-4$ & $9.33 \mathrm{E}-5$ \\
\hline .50 III INIT Sr & - & $1.23 \mathrm{E}-5$ & 6 & 9.32 & $1.43 \mathrm{E}-5$ & $1.67 \mathrm{E}-2$ & $7.69 \mathrm{E}-5$ & $2.81 \mathrm{E}-4$ & $6.59 \mathrm{E}-5$ \\
\hline
\end{tabular}


Table D-3. Data for cesium $(0.1 \mathrm{mg} / \mathrm{L})$ sorption to $\mathrm{U}-1 \mathrm{a}$ alluvium.

\begin{tabular}{|c|c|c|c|c|c|c|c|c|c|c|}
\hline \multirow{3}{*}{$\begin{array}{l}\text { Sample } \\
\text { Name }\end{array}$} & \multirow{3}{*}{$\begin{array}{l}\text { Solid } \\
\text { Conc. } \\
\mathrm{g} / \mathrm{mL}\end{array}$} & \multirow{3}{*}{$\begin{array}{c}\text { Cs } \\
\text { Added } \\
\text { mol/l }\end{array}$} & \multirow{3}{*}{$\begin{array}{c}\text { Sorption } \\
\text { Time } \\
\text { days }\end{array}$} & \multirow{3}{*}{$\begin{array}{c}\text { Final } \\
\mathrm{pH}\end{array}$} & \multicolumn{6}{|c|}{ Final Concentration } \\
\hline & & & & & Cs & $\mathrm{Sr}$ & $\mathrm{Na}$ & N & K & $\mathrm{a}$ \\
\hline & & & & & \multicolumn{6}{|c|}{$\mathrm{mol} / \mathrm{L}$} \\
\hline $7.50 \mathrm{I} \mathrm{Cs}$ & 0.054 & $8.82 \mathrm{E}-7$ & 6 & 7.43 & $1.49 \mathrm{E}-8$ & $4.43 \mathrm{E}-5$ & $8.85 \mathrm{E}-4$ & $2.65 \mathrm{E}-3$ & $9.45 \mathrm{E}-4$ & $3.24 \mathrm{E}-2$ \\
\hline $.75 \mathrm{I} \mathrm{Cs}$ & 0.055 & $8.75 \mathrm{E}-7$ & 6 & 7.69 & $8.44 \mathrm{E}-9$ & $2.71 \mathrm{E}-5$ & $9.62 \mathrm{E}-4$ & $2.16 \mathrm{E}-3$ & 7.82E-4 & $9.74 \mathrm{E}-3$ \\
\hline $3.00 \mathrm{I} \mathrm{Cs}$ & 0.056 & $8.86 \mathrm{E}-7$ & 6 & 7.96 & $7.20 \mathrm{E}-9$ & $1.24 \mathrm{E}-5$ & $1.18 \mathrm{E}-3$ & $1.27 \mathrm{E}-3$ & $6.02 \mathrm{E}-4$ & $2.19 \mathrm{E}-3$ \\
\hline $.25 \mathrm{I} \mathrm{Cs}$ & 0.056 & $8.86 \mathrm{E}-7$ & 6 & 8.20 & $5.63 \mathrm{E}-9$ & 4.27E-6 & $1.32 \mathrm{E}-3$ & $5.84 \mathrm{E}-4$ & 4.59E-4 & 7.30E-4 \\
\hline $.50 \mathrm{I} \mathrm{Cs}$ & 0.056 & $8.87 \mathrm{E}-7$ & 6 & 8.35 & $4.88 \mathrm{E}-9$ & $2.13 \mathrm{E}-6$ & $2.27 \mathrm{E}-3$ & $2.97 \mathrm{E}-4$ & $3.99 \mathrm{E}-4$ & $3.32 \mathrm{E}-4$ \\
\hline $.75 \mathrm{I} \mathrm{Cs}$ & 0.055 & $8.81 \mathrm{E}-7$ & 6 & 8.51 & $4.22 \mathrm{E}-9$ & $1.13 \mathrm{E}-6$ & $3.67 \mathrm{E}-3$ & $1.37 \mathrm{E}-4$ & $4.02 \mathrm{E}-4$ & $1.69 \mathrm{E}-4$ \\
\hline $.00 \mathrm{I} \mathrm{Cs}$ & 0.054 & $8.72 \mathrm{E}-7$ & 7.5 & 9.05 & $1.82 \mathrm{E}-9$ & $2.51 \mathrm{E}-7$ & $6.12 \mathrm{E}-3$ & $4.16 \mathrm{E}-5$ & $1.87 \mathrm{E}-4$ & $3.24 \mathrm{E}-5$ \\
\hline $.25 \mathrm{I} \mathrm{Cs}$ & 0.053 & $8.51 \mathrm{E}-7$ & 7.5 & 9.34 & $1.90 \mathrm{E}-9$ & $2.01 \mathrm{E}-7$ & $9.71 \mathrm{E}-3$ & $3.30 \mathrm{E}-5$ & $1.84 \mathrm{E}-4$ & $2.14 \mathrm{E}-5$ \\
\hline $.50 \mathrm{I} \mathrm{Cs}$ & 0.051 & $8.26 \mathrm{E}-7$ & 7.5 & 9.43 & $3.31 \mathrm{E}-9$ & $4.02 \mathrm{E}-7$ & $1.89 \mathrm{E}-2$ & $6.43 \mathrm{E}-5$ & $2.50 \mathrm{E}-4$ & $2.47 \mathrm{E}-5$ \\
\hline $.50 \mathrm{II} \mathrm{Cs}$ & 0.050 & $8.11 \mathrm{E}-7$ & 6 & 7.45 & $9.60 \mathrm{E}-9$ & $4.54 \mathrm{E}-5$ & $9.00 \mathrm{E}-4$ & $2.72 \mathrm{E}-3$ & 8.81E-4 & $3.44 \mathrm{E}-2$ \\
\hline $7.75 \mathrm{II} \mathrm{Cs}$ & 0.051 & $8.14 \mathrm{E}-7$ & 6 & 7.69 & $6.62 \mathrm{E}-9$ & $2.65 \mathrm{E}-5$ & $9.23 \mathrm{E}-4$ & $2.12 \mathrm{E}-3$ & $6.53 \mathrm{E}-4$ & $9.94 \mathrm{E}-3$ \\
\hline $3.00 \mathrm{II} \mathrm{Cs}$ & 0.050 & $8.04 \mathrm{E}-7$ & 6 & 7.97 & $5.88 \mathrm{E}-9$ & $1.21 \mathrm{E}-5$ & $1.14 \mathrm{E}-3$ & $1.24 \mathrm{E}-3$ & 5.01E-4 & $2.18 \mathrm{E}-3$ \\
\hline $3.25 \mathrm{II} \mathrm{Cs}$ & 0.051 & $8.11 \mathrm{E}-7$ & 6 & 8.21 & $5.46 \mathrm{E}-9$ & $4.27 \mathrm{E}-6$ & $1.35 \mathrm{E}-3$ & $5.93 \mathrm{E}-4$ & $4.14 \mathrm{E}-4$ & 7.33E-4 \\
\hline $3.50 \mathrm{II} \mathrm{Cs}$ & 0.050 & $8.03 \mathrm{E}-7$ & 6 & 8.35 & $4.88 \mathrm{E}-9$ & $2.01 \mathrm{E}-6$ & $2.33 \mathrm{E}-3$ & 2.97E-4 & $3.68 \mathrm{E}-4$ & $3.22 \mathrm{E}-4$ \\
\hline $3.75 \mathrm{II} \mathrm{Cs}$ & 0.050 & $8.05 \mathrm{E}-7$ & 6 & 8.53 & $4.39 \mathrm{E}-9$ & $1.13 \mathrm{E}-6$ & $3.82 \mathrm{E}-3$ & $1.33 \mathrm{E}-4$ & $3.06 \mathrm{E}-4$ & $1.71 \mathrm{E}-4$ \\
\hline $.00 \mathrm{II} \mathrm{Cs}$ & 0.049 & 7.91E-7 & 7.5 & 9.06 & $1.74 \mathrm{E}-9$ & $3.26 \mathrm{E}-7$ & $6.32 \mathrm{E}-3$ & 4.43E-5 & $1.88 \mathrm{E}-4$ & 4.64E-5 \\
\hline $9.25 \mathrm{II} \mathrm{Cs}$ & 0.049 & $7.86 \mathrm{E}-7$ & 7.5 & 9.34 & $1.82 \mathrm{E}-9$ & $2.13 \mathrm{E}-7$ & $1.01 \mathrm{E}-2$ & $3.53 \mathrm{E}-5$ & $1.75 \mathrm{E}-4$ & $2.36 \mathrm{E}-5$ \\
\hline $.50 \mathrm{II} \mathrm{Cs}$ & 0.049 & $7.83 \mathrm{E}-7$ & 7.5 & 9.44 & $4.30 \mathrm{E}-9$ & 4.27E-7 & $1.69 \mathrm{E}-2$ & $6.83 \mathrm{E}-5$ & $2.52 \mathrm{E}-4$ & $3.71 \mathrm{E}-5$ \\
\hline 7.50 III INIT Cs & 0.050 & 8.07E-7 & 6 & 7.44 & $7.95 \mathrm{E}-7$ & $4.47 \mathrm{E}-5$ & $9.00 \mathrm{E}-4$ & $2.70 \mathrm{E}-3$ & $7.03 \mathrm{E}-4$ & $3.40 \mathrm{E}-2$ \\
\hline 7.75 III INIT Cs & 0.050 & 8.07E-7 & 6 & 7.69 & $7.84 \mathrm{E}-7$ & $2.62 \mathrm{E}-5$ & $9.33 \mathrm{E}-4$ & $2.10 \mathrm{E}-3$ & $5.54 \mathrm{E}-4$ & $9.88 \mathrm{E}-3$ \\
\hline 8.00 III INIT Cs & 0.051 & 8.07E-7 & 6 & 7.97 & 7.43E-7 & $1.17 \mathrm{E}-5$ & $1.10 \mathrm{E}-3$ & $1.21 \mathrm{E}-3$ & $3.97 \mathrm{E}-4$ & $2.15 \mathrm{E}-3$ \\
\hline 3.25 III INIT Cs & 0.051 & $8.07 \mathrm{E}-7$ & 6 & 8.21 & $7.45 \mathrm{E}-7$ & $4.39 \mathrm{E}-6$ & $1.32 \mathrm{E}-3$ & 5.93E-4 & $3.26 \mathrm{E}-4$ & 7.88E-4 \\
\hline 8.50 III INIT Cs & 0.051 & $8.07 \mathrm{E}-7$ & 6 & 8.35 & 7.76E-7 & $2.13 \mathrm{E}-6$ & $2.26 \mathrm{E}-3$ & $2.98 \mathrm{E}-4$ & 2.79E-4 & $3.46 \mathrm{E}-4$ \\
\hline 8.75 III INIT Cs & 0.049 & $8.07 \mathrm{E}-7$ & 6 & 8.52 & $7.53 \mathrm{E}-7$ & $1.08 \mathrm{E}-6$ & $3.73 \mathrm{E}-3$ & $1.58 \mathrm{E}-4$ & 2.44E-4 & 1.79E-4 \\
\hline 9.00 III INIT Cs & 0.049 & $8.07 \mathrm{E}-7$ & 7.5 & 9.06 & 7.75E-7 & $3.77 \mathrm{E}-7$ & $6.46 \mathrm{E}-3$ & $5.20 \mathrm{E}-5$ & 2.01E-4 & 4.83E-5 \\
\hline 9.25 III INIT Cs & 0.050 & $8.07 \mathrm{E}-7$ & 7.5 & 9.34 & 7.77E-7 & $2.51 \mathrm{E}-7$ & $1.02 \mathrm{E}-2$ & 4.62E-5 & $1.92 \mathrm{E}-4$ & $3.62 \mathrm{E}-5$ \\
\hline 9.50 III INIT Cs & 0.049 & 8.07E-7 & 7.5 & 9.44 & $7.92 \mathrm{E}-7$ & $5.02 \mathrm{E}-7$ & $1.98 \mathrm{E}-2$ & $9.19 \mathrm{E}-5$ & $2.87 \mathrm{E}-4$ & $4.31 \mathrm{E}-5$ \\
\hline
\end{tabular}


Table D-4. Data for europium $(0.1 \mathrm{mg} / \mathrm{L})$ sorption to U-1a alluvium.

\begin{tabular}{|c|c|c|c|c|c|c|c|c|c|c|}
\hline \multirow{3}{*}{$\begin{array}{l}\text { Sample } \\
\text { Name }\end{array}$} & \multirow{3}{*}{$\begin{array}{l}\text { Solid } \\
\text { Conc. } \\
\mathrm{g} / \mathrm{mL}\end{array}$} & \multirow{3}{*}{$\begin{array}{c}\mathrm{Eu} \\
\text { Added } \\
\mathrm{mol} / \mathrm{l}\end{array}$} & \multirow{3}{*}{$\begin{array}{l}\text { Sorption } \\
\text { Time } \\
\text { days }\end{array}$} & \multirow{3}{*}{$\begin{array}{c}\text { Final } \\
\mathrm{pH}\end{array}$} & \multicolumn{2}{|c|}{--------------- H } & \multicolumn{2}{|c|}{ Final Concentration } & \multicolumn{2}{|c|}{------------------ } \\
\hline & & & & & $\mathrm{Eu}$ & $\mathrm{Sr}$ & $\mathrm{Na}$ & $\mathrm{Mg}$ & K & $\mathrm{Ca}$ \\
\hline & & & & & & & & & & \\
\hline $50 \mathrm{I} \mathrm{Eu}$ & 0.054 & $7.46 \mathrm{E}-7$ & 7.5 & 7.46 & $1.23 \mathrm{E}-9$ & $4.65 \mathrm{E}-5$ & $9.52 \mathrm{E}-4$ & $2.85 \mathrm{E}-3$ & $8.36 \mathrm{E}-4$ & $3.43 \mathrm{E}$ \\
\hline $75 \mathrm{I} \mathrm{Eu}$ & 054 & $45 \mathrm{E}-7$ & 7.5 & 7.70 & $5.07 \mathrm{E}-10$ & $2.80 \mathrm{E}-5$ & $1.00 \mathrm{E}-3$ & $2.25 \mathrm{E}-3$ & $6.78 \mathrm{E}-4$ & $1.03 \mathrm{E}-2$ \\
\hline $8.00 \mathrm{I} \mathrm{Eu}$ & 152 & $13 \mathrm{E}-7$ & 7.5 & 7.96 & 2.90 & $1.26 \mathrm{E}-5$ & $1.22 \mathrm{E}-3$ & $1.28 \mathrm{E}-3$ & $4.98 \mathrm{E}-4$ & $2.40 \mathrm{E}-3$ \\
\hline $.25 \mathrm{I} \mathrm{Eu}$ & 054 & $7.51 \mathrm{E}-7$ & 7.5 & 8.21 & $2.17 \mathrm{E}-10$ & $4.52 \mathrm{E}-6$ & $1.37 \mathrm{E}-3$ & $5.88 \mathrm{E}-4$ & $3.77 \mathrm{E}-4$ & $7.82 \mathrm{E}-4$ \\
\hline $0 \mathrm{I}$ Eu & 154 & IE-7 & 7.5 & 8.44 & 2.17 & 2.01E-6 & $2.76 \mathrm{E}-3$ & 2.63E-4 & & $3.10 \mathrm{E}-4$ \\
\hline $15 \mathrm{I} \mathrm{Eu}$ & 51 & $9 \mathrm{E}-7$ & 10 & 8.72 & 1.4 & $8.79 \mathrm{E}-7$ & $4.49 \mathrm{E}-3$ & $9.95 \mathrm{E}-5$ & & $1.33 \mathrm{E}-4$ \\
\hline $00 \mathrm{I} E u$ & 52 & $7.00 \mathrm{E}-7$ & 10 & 9.06 & 2.1 & E-7 & $6.84 \mathrm{E}-3$ & $4.82 \mathrm{E}-5$ & $E-4$ & $7.48 \mathrm{E}-5$ \\
\hline $25 \mathrm{I}$ Eu & 51 & $4 \mathrm{E}-7$ & 10 & 9.18 & 2.1 & $3.77 \mathrm{E}-7$ & $9.90 \mathrm{E}-3$ & 4.34E-5 & 1.8 & $6.64 \mathrm{E}-5$ \\
\hline $\mathrm{Eu}$ & 1 & 7 & 10 & 9.41 & & 5.0 & $1.86 \mathrm{E}-2$ & 7.42E-5 & & $5.35 \mathrm{E}-5$ \\
\hline $50 \mathrm{I}$ & 50 & $0 \mathrm{E}-7$ & 7.5 & 7.47 & 7.2 & 4.7 & $9.95 \mathrm{E}-4$ & $2.87 \mathrm{E}-3$ & $E-4$ & $3.57 \mathrm{E}-2$ \\
\hline $.75 \mathrm{II}$ & 51 & $2 \mathrm{E}-7$ & 7.5 & 7.72 & 3.6 & 2.9 & $1.07 \mathrm{E}-3$ & $2.36 \mathrm{E}-3$ & 6.7 & $1.11 \mathrm{E}-2$ \\
\hline $0 \mathrm{II}$ & 4 & -7 & 7.5 & 8.00 & 2.1 & -5 & $1.25 \mathrm{E}-3$ & $1.32 \mathrm{E}-3$ & 4.9 & $2.47 \mathrm{E}-3$ \\
\hline II Eu & 0 & -7 & 7.5 & 8.23 & 1.4 & 4.7 & $1.47 \mathrm{E}-3$ & $6.33 \mathrm{E}-4$ & 3.8 & $8.65 \mathrm{E}-4$ \\
\hline $50 \mathrm{II} \mathrm{Eu}$ & 51 & $7 \mathrm{E}-7$ & 7.5 & 8.46 & 2.1 & 2.0 & $2.71 \mathrm{E}-3$ & $2.61 \mathrm{E}-4$ & $E-4$ & $3.10 \mathrm{E}-4$ \\
\hline 75 II Eu & 50 & $35 \mathrm{E}-7$ & 10 & 8.74 & 1.45 & $8.79 \mathrm{E}-7$ & $4.58 \mathrm{E}-3$ & $1.01 \mathrm{E}-4$ & $2.52 \mathrm{E}-4$ & $1.42 \mathrm{E}-4$ \\
\hline $9.00 \mathrm{II}$ & 50 & IE-7 & 10 & 9.07 & 2.1 & $5.02 \mathrm{E}-7$ & $6.60 \mathrm{E}-3$ & $4.75 \mathrm{E}-5$ & E-4 & $6.07 \mathrm{E}-5$ \\
\hline $25 \mathrm{II} \mathrm{Eu}$ & 49 & E-7 & 10 & 9.19 & 2.1 & $3.77 \mathrm{E}-7$ & $8.90 \mathrm{E}-3$ & $3.85 \mathrm{E}-5$ & E-4 & $1.98 \mathrm{E}-5$ \\
\hline $.50 \mathrm{II} \mathrm{Eu}$ & 49 & $2 \mathrm{E}-7$ & 10 & 9.42 & 3.62 & $6.28 \mathrm{E}-7$ & $1.88 \mathrm{E}-2$ & $7.92 \mathrm{E}-5$ & E-4 & $6.07 \mathrm{E}-5$ \\
\hline $7.5 \mathrm{III} \mathrm{Eu}$ & 0.050 & $6.91 \mathrm{E}-7$ & 7.5 & 7.47 & 5.3 & $4.70 \mathrm{E}-5$ & $1.03 \mathrm{E}-3$ & $2.90 \mathrm{E}-3$ & $8.75 \mathrm{E}-4$ & $3.61 \mathrm{E}-2$ \\
\hline 7.75 III IN & 050 & $91 \mathrm{E}-7$ & 7.5 & 7.73 & 5.89 & $2.80 \mathrm{E}-5$ & $1.00 \mathrm{E}-3$ & $2.24 \mathrm{E}-3$ & $6.67 \mathrm{E}-4$ & $1.07 \mathrm{E}-2$ \\
\hline 8.00 III INI & 0.051 & $6.91 \mathrm{E}-7$ & 7.5 & 8.00 & 5.4 & $1.31 \mathrm{E}-5$ & $1.26 \mathrm{E}-3$ & $1.33 \mathrm{E}-3$ & 4.84E-4 & $2.58 \mathrm{E}-3$ \\
\hline 8.25 III INIT Eu & 0.050 & $6.91 \mathrm{E}-7$ & 7.5 & 8.25 & & $4.77 \mathrm{E}-6$ & $1.47 \mathrm{E}-3$ & $6.33 \mathrm{E}-4$ & $3.85 \mathrm{E}-4$ & $8.78 \mathrm{E}-4$ \\
\hline 8.50 III INIT Eu & 0.051 & $6.91 \mathrm{E}-7$ & 7.5 & 8.53 & $6.71 \mathrm{E}-7$ & $1.46 \mathrm{E}-5$ & $2.76 \mathrm{E}-3$ & $2.68 \mathrm{E}-4$ & $3.15 \mathrm{E}-4$ & $3.18 \mathrm{E}-4$ \\
\hline $8.75 \mathrm{II}$ & 0.052 & $6.91 \mathrm{E}-7$ & 10 & 8.86 & 6.8 & $8.79 \mathrm{E}-7$ & $4.58 \mathrm{E}-3$ & $1.14 \mathrm{E}-4$ & $2.57 \mathrm{E}-4$ & $1.50 \mathrm{E}-4$ \\
\hline 9.00 III IN & 0.051 & $6.91 \mathrm{E}-7$ & 10 & 9.19 & 6.93 & $5.02 \mathrm{E}-7$ & $6.99 \mathrm{E}-3$ & $6.24 \mathrm{E}-5$ & $2.02 \mathrm{E}-4$ & $7.66 \mathrm{E}-5$ \\
\hline 9.25 III INIT Eu & 0.051 & $6.91 \mathrm{E}-7$ & 10 & 9.27 & $6.91 \mathrm{E}-7$ & $5.02 \mathrm{E}-7$ & $1.02 \mathrm{E}-2$ & $5.79 \mathrm{E}-5$ & $2.02 \mathrm{E}-4$ & $6.70 \mathrm{E}-5$ \\
\hline 9.50 III INIT Eu & 0.049 & $6.91 \mathrm{E}-7$ & 10 & 9.45 & $6.83 \mathrm{E}-7$ & $6.28 \mathrm{E}-7$ & $1.89 \mathrm{E}-2$ & $1.02 \mathrm{E}-4$ & $2.84 \mathrm{E}-4$ & $6.67 \mathrm{E}-5$ \\
\hline
\end{tabular}


Table D-5. Data for samarium $(0.1 \mathrm{mg} / \mathrm{L})$ sorption to U-1a alluvium.

\begin{tabular}{|c|c|c|c|c|c|c|c|c|}
\hline \multirow{3}{*}{$\begin{array}{l}\text { Sample } \\
\text { Name }\end{array}$} & \multirow{3}{*}{$\begin{array}{l}\text { Solid } \\
\text { Conc. } \\
\mathrm{g} / \mathrm{mL}\end{array}$} & \multirow{3}{*}{$\begin{array}{l}\mathrm{Sm} \\
\text { Added } \\
\mathrm{mol} / 1\end{array}$} & \multirow{3}{*}{\multicolumn{2}{|c|}{$\begin{array}{ll}\text { Sorption } & \text { Final } \\
\text { Time } & \mathrm{pH}\end{array}$}} & \multicolumn{4}{|c|}{ 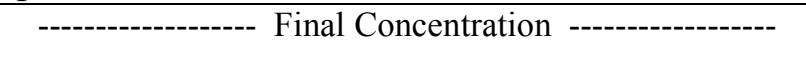 } \\
\hline & & & & & $\mathrm{Sm}$ & $\mathrm{Sr}$ & $\mathrm{Mg}$ & $\mathrm{Ca}$ \\
\hline & & & & & & & & \\
\hline $7.50 \mathrm{I} \mathrm{Sm}$ & 0.054 & $8.22 \mathrm{E}-7$ & 10 & 7.41 & $1.10 \mathrm{E}-9$ & $4.62 \mathrm{E}-5$ & $9.43 \mathrm{E}-42.77 \mathrm{E}-3$ & $7.74 \mathrm{E}-4 \quad 3.29 \mathrm{E}-2$ \\
\hline 7.75 I Sm & 0.052 & 7.99E-7 & 10 & 7.64 & $3.66 \mathrm{E}-10$ & $2.77 \mathrm{E}-5$ & $9.71 \mathrm{E}-4$ 2.17E-3 & $6.22 \mathrm{E}-4 \quad 9.96 \mathrm{E}-3$ \\
\hline $8.00 \mathrm{I} \mathrm{Sm}$ & 0.052 & $7.89 \mathrm{E}-7$ & 10 & 7.91 & $2.19 \mathrm{I}$ & $1.24 \mathrm{E}-5$ & $1.19 \mathrm{E}-3 \quad 1.26 \mathrm{E}-3$ & $4.53 \mathrm{E}-4 \quad 2.26 \mathrm{E}-3$ \\
\hline $8.25 \mathrm{I} \mathrm{Sm}$ & 0.053 & 7.87E-7 & 10 & 8.16 & 1.46 & 4.39E-6 & $1.35 \mathrm{E}-3 \quad 5.84 \mathrm{E}-4$ & $3.54 \mathrm{E}-4 \quad 7.55 \mathrm{E}-4$ \\
\hline $8.50 \mathrm{I} \mathrm{Sm}$ & 0.053 & $7.84 \mathrm{E}-7$ & 7 & 8.41 & 2.19 & $2.01 \mathrm{E}-6$ & $2.61 \mathrm{E}-3 \quad 2.66 \mathrm{E}-4$ & $5.91 \mathrm{E}-4$ 2.91E-4 \\
\hline $8.75 \mathrm{I} \mathrm{Sm}$ & 0.053 & $7.93 \mathrm{E}-7$ & 7 & 8. & 2.1 & $8.79 \mathrm{E}-7$ & 4.14E-3 9.19E-5 & E-4 1. \\
\hline $9.00 \mathrm{I} \mathrm{Sm}$ & 0.054 & $7.86 \mathrm{E}-7$ & 7 & 0 & 0 & $5.02 \mathrm{E}-7$ & $6.36 \mathrm{E}-3$ 4.84E-5 & $3.88 \mathrm{E}-45.7$ \\
\hline $9.25 \mathrm{I} \mathrm{Sm}$ & 0.053 & $7.86 \mathrm{E}-7$ & 7 & 9.16 & & $3.77 \mathrm{E}-7$ & 9.09E-3 4.12E-5 & $3.54 \mathrm{E}-42.91 \mathrm{E}-5$ \\
\hline $9.50 \mathrm{I} \mathrm{Sm}$ & 0.051 & 7.63E-7 & 7 & 9.40 & 5.12 & $5.02 \mathrm{E}-7$ & 1.84E-2 7.19E-5 & $4.50 \mathrm{E}-4$ 3.13E-5 \\
\hline $7.50 \mathrm{II} \mathrm{Sm}$ & 0.051 & $7.60 \mathrm{E}-7$ & 10 & 7.44 & 2.9 & $4.49 \mathrm{E}-5$ & 9.04E-4 2.69E-3 & $7.29 \mathrm{E}-4 \quad 3.27 \mathrm{E}-2$ \\
\hline $7.75 \mathrm{II} \mathrm{Sm}$ & 0.050 & 7.63E-7 & 10 & 7.68 & $2.19 \mathrm{E}$ & $2.72 \mathrm{E}-5$ & 9.47E-4 2.13E-3 & $5.99 \mathrm{E}-4 \quad 9.94 \mathrm{E}-3$ \\
\hline $8.00 \mathrm{II} \mathrm{Sm}$ & 0.051 & $7.66 \mathrm{E}-7$ & 10 & 7.96 & $2.19 \mathrm{E}-10$ & $1.24 \mathrm{E}-5$ & $1.20 \mathrm{E}-3 \quad 1.27 \mathrm{E}-3$ & $4.59 \mathrm{E}-4 \quad 2.32 \mathrm{E}-3$ \\
\hline $8.25 \mathrm{II} \mathrm{Sm}$ & 0.051 & $7.66 \mathrm{E}-7$ & 10 & 8.19 & $1.46 \mathrm{E}-10$ & $4.52 \mathrm{E}-6$ & $1.36 \mathrm{E}-3 \quad 5.93 \mathrm{E}-4$ & $3.54 \mathrm{E}-4$ 7.77E-4 \\
\hline $8.50 \mathrm{II} \mathrm{Sm}$ & 0.049 & $7.45 \mathrm{E}-7$ & 7 & 8.44 & $1.46 \mathrm{E}-10$ & $1.88 \mathrm{E}-6$ & $2.54 \mathrm{E}-3 \quad 2.52 \mathrm{E}-4$ & $5.06 \mathrm{E}-4 \quad 2.72 \mathrm{E}-4$ \\
\hline $8.75 \mathrm{II} \mathrm{Sm}$ & 0.049 & $7.41 \mathrm{E}-7$ & 7 & 8.74 & $2.19 \mathrm{E}-10$ & $8.79 \mathrm{E}-7$ & 4.33E-3 9.73E-5 & $4.16 \mathrm{E}-4 \quad 1.10 \mathrm{E}-4$ \\
\hline $9.00 \mathrm{II} \mathrm{Sm}$ & 0.050 & $7.53 \mathrm{E}-7$ & 7 & 9.08 & $2.93 \mathrm{E}-10$ & $5.02 \mathrm{E}-7$ & $6.36 \mathrm{E}-3 \quad 4.71 \mathrm{E}-5$ & $3.24 \mathrm{E}-4 \quad 5.30 \mathrm{E}-5$ \\
\hline $9.25 \mathrm{II} \mathrm{Sm}$ & 0.050 & $7.50 \mathrm{E}-7$ & 7 & 9.18 & -10 & $3.77 \mathrm{E}-7$ & $9.09 \mathrm{E}-3 \quad 4.25 \mathrm{E}-5$ & $4.08 \mathrm{E}-4 \quad 3.76 \mathrm{E}-5$ \\
\hline $9.50 \mathrm{II} \mathrm{Sm}$ & 0.049 & $7.36 \mathrm{E}-7$ & 7 & 9.42 & $5.85 \mathrm{E}-10$ & $5.02 \mathrm{E}-7$ & 1.89E-2 7.42E-5 & $4.16 \mathrm{E}-4 \quad 3.10 \mathrm{E}-5$ \\
\hline 7.50 III INIT Sm & 0.050 & $7.61 \mathrm{E}-7$ & 0 & 7.50 & $5.58 \mathrm{E}-7$ & 4.47E-5 & $9.04 \mathrm{E}-4 \quad 2.69 \mathrm{E}-3$ & 7.03E-4 3.34E-2 \\
\hline 7.75 III INIT Sm & 0.051 & $7.61 \mathrm{E}-7$ & 0 & 7.74 & $5.14 \mathrm{E}-7$ & $2.76 \mathrm{E}-5$ & $9.52 \mathrm{E}-42.18 \mathrm{E}-3$ & $5.85 \mathrm{E}-4 \quad 1.02 \mathrm{E}-2$ \\
\hline 8.00 III INIT Sm & 0.053 & $7.61 \mathrm{E}-7$ & U & 8.00 & $3.70 \mathrm{E}-7$ & $1.23 \mathrm{E}-5$ & $1.16 \mathrm{E}-3 \quad 1.24 \mathrm{E}-3$ & $4.22 \mathrm{E}-4 \quad 2.30 \mathrm{E}-3$ \\
\hline 8.25 III INIT Sm & 0.051 & $7.61 \mathrm{E}-7$ & 10 & 8.23 & $4.70 \mathrm{E}-7$ & $4.52 \mathrm{E}-6$ & $1.39 \mathrm{E}-3 \quad 6.02 \mathrm{E}-4$ & $3.46 \mathrm{E}-4$ 7.99E-4 \\
\hline 8.50 III INIT Sm & 0.050 & $7.61 \mathrm{E}-7$ & 7 & 8.48 & $6.64 \mathrm{E}-7$ & $2.01 \mathrm{E}-6$ & $2.66 \mathrm{E}-3 \quad 2.65 \mathrm{E}-4$ & 4.22E-4 $3.02 \mathrm{E}-4$ \\
\hline 8.75 III INIT Sm & 0.050 & $7.61 \mathrm{E}-7$ & 7 & 8.86 & $6.72 \mathrm{E}-7$ & $8.79 \mathrm{E}-7$ & $4.20 \mathrm{E}-3 \quad 9.50 \mathrm{E}-5$ & $3.21 \mathrm{E}-4 \quad 1.27 \mathrm{E}-4$ \\
\hline 9.00 III INIT Sm & 0.050 & $7.61 \mathrm{E}-7$ & 7 & 9.18 & $6.90 \mathrm{E}-7$ & $5.02 \mathrm{E}-7$ & $6.41 \mathrm{E}-3$ 5.16E-5 & $3.35 \mathrm{E}-4 \quad 6.53 \mathrm{E}-5$ \\
\hline 9.25 III INIT Sm & 0.050 & $7.61 \mathrm{E}-7$ & 7 & 9.28 & $6.94 \mathrm{E}-7$ & $3.77 \mathrm{E}-7$ & $9.43 \mathrm{E}-3 \quad 4.80 \mathrm{E}-5$ & $3.29 \mathrm{E}-4 \quad 4.09 \mathrm{E}-5$ \\
\hline 9.50 III INIT Sm & 0.049 & 7.61E-7 & 7 & 9.44 & $2.36 \mathrm{E}-7$ & $6.28 \mathrm{E}-7$ & $1.87 \mathrm{E}-2 \quad 8.46 \mathrm{E}-5$ & $3.80 \mathrm{E}-4 \quad 4.50 \mathrm{E}-5$ \\
\hline
\end{tabular}




\section{Appendix E. Surface Complexation, Ion Exchange, and Aqueous Speciation Constants and Mineral Characteristics Used in Mechanistic Sorption Model}

Table E-1 lists the radionuclide-mineral surface complexation reactions accounted for in our reactive transport model. Table E-2 lists the ion exchange reactions accounted for in our model. While the radionuclide-mineral reactions used in our near-field model represent a large proportion of reactions expected to control radionuclide migration in the near-field, several notable reactions are missing. In particular, manganese oxide minerals may play an important role in decreasing radionuclide migration but published sorption data are scarce. Data from Keeney-Kennicutt and Morse (1984) suggests that calcite and goethite sorb neptunium much more strongly than $\delta-\mathrm{MnO}_{2}$ or Na-montmorillonite (a smectite). Although this suggests that manganese oxides may not be the primary sorbers for some radionuclides, the sorptive capacity of the many different manganese oxide minerals still need to be examined. In addition to the absence of manganese oxide reactions, some radionuclide-mineral interactions had to be approximated. For Sm(III), data regarding sorption to iron oxides and aluminosilicates were not available in the literature. Thus, its surface complexation constants were assumed to be equivalent to those of $\mathrm{Eu}(\mathrm{III})$. This is not altogether unreasonable; rare earth elements are often assumed to behave similarly, with retardation coefficients decreasing slightly with increased rare earth element atomic number (see calcite data of Zhong and Mucci (1995) and goethite data of Koeppenkastrop and Decarlo (1992)).

All surface complexation and ion exchange reactions used in our near-field model are listed in Tables E-3 to E-6. The reaction constants were calculated by fitting published sorption data to the NEM and Vanselow models or by using published reaction constants directly. References to the large set of sorption data used are listed in Zavarin and Bruton (2000a; 2000b). When multiple sets of data were evaluated, a standard deviation was calculation for each reaction constant. These values can be used to evaluate the uncertainty in reaction constants and, in turn, radionuclide retardation.

To use the surface complexation and ion exchange constants of Table E-3 to E-6, additional mineral characteristics need to be established. These are: surface area, reactive site type, reactive site density, and cation exchange capacity for each mineral. These parameters are listed in Table E-7. Iron oxide surface area was based on hematite (Hsi and Langmuir, 1985); this should lead to a conservative estimate of the sorptive capacity of iron oxides. The reactive site density was taken from a Dzombak and Morel (1990) estimate of site density on hydrous ferric oxide. Unlike Dzombak and Morel (1990), only one site was used in our model (see Zavarin and Bruton (2000a; 2000b)). The calcite surface area and site density was taken from Zachara et al. (1993). Smectite surface area was taken from McKinley et al. (1995). The site density was determined by estimating that $10 \%$ of the smectite surface accounts for edge sites and that the site density at those edge sites is 2.31 per $\mathrm{nm}^{2}$. The fraction of $>\mathrm{SiOH}$ and $>\mathrm{AlOH}$ sites on the smectite is consistent with values proposed by McKinley et al. (1995) and Turner et al. (1996). The cation exchange capacities of smectite, clinoptilolite, and illite were taken from Viani and Bruton (1992; 1996). 
Thermodynamic data for aqueous species were taken from version com.V8.R6 of the GEMBOCHS thermodynamic database (Johnson and Lundeen, 1997) with revised and updated thermodynamic data as given in Tompson et al. (Tompson et al., 1999) and noted below. The thermodynamic data used in the simulations is listed in Tables E-8 through E10. The choice of aqueous species used in the simulations is based on our simulation of Frenchman Flat groundwaters and a wide range of $\mathrm{pH}$.

The extended Debye-Hückel formulation (also known as the B-DOT model) was used for activity coefficients of aqueous species (Bethke, 1996; Helgeson, 1969). This formulation is well suited to describe the groundwaters at NTS, which possess ionic strengths significantly less than 0.1. Values of the ion size parameter (Bethke, 1996; Helgeson, 1969) for aqueous species added to the database were estimated by analogy to aqueous species of similar valence and ligand. Parameters used in the Debye-Hückel activity coefficient model are listed in Tables E-8 and E-9.

Table E-1. Radionuclide-mineral interactions described by nonelectrostatic surface complexation.

\begin{tabular}{cccc}
\hline Element & Iron Oxide & Calcite & Aluminosilicate $\dagger$ \\
\hline $\mathrm{Cs}(\mathrm{I})$ & $\mathbb{9}$ & $\mathbb{I}$ & $\ddagger$ \\
$\mathrm{Eu}(\mathrm{III})$ & $\sqrt{ }$ & $\sqrt{ }$ & $\sqrt{ }$ \\
$\mathrm{Np}(\mathrm{V})$ & $\sqrt{ }$ & $\sqrt{ }$ & $\sqrt{ }$ \\
$\mathrm{Sm}(\mathrm{III})$ & $\S$ & $\sqrt{ }$ & $\S$ \\
$\mathrm{Sr}(\mathrm{II})$ & $\sqrt{ }$ & $\sqrt{ }$ & $\ddagger$ \\
$\mathrm{U}(\mathrm{VI})$ & $\sqrt{ }$ & $\sqrt{ }$ & $\sqrt{ }$ \\
\hline
\end{tabular}

$\dagger$ Surface complexation to aluminosilicates modeled assuming smectite to be the dominant reactive aluminosilicate.

* Sorption to aluminosilicates via ion exchange

- This radionuclide-mineral interaction was not taken into account but is known to be relatively insignificant

$\S \mathrm{Sm}(\mathrm{III})$-iron oxide and Sm-aluminosilicate interaction was estimated using the reaction constants of $\mathrm{Eu}(\mathrm{III})$ because data were not available.

Table E-2. Radionuclide-mineral interactions described by Vanselow ion exchange.

\begin{tabular}{cccc}
\hline Element & smectite & illite/mica & zeolite (clinoptilolite) \\
\hline $\mathrm{Na}^{+}$ & $\sqrt{ }$ & $\sqrt{ }$ & $\sqrt{ }$ \\
$\mathrm{K}^{+}$ & $\sqrt{ }$ & $\sqrt{ }$ & $\sqrt{ }$ \\
$\mathrm{Ca}^{2+}$ & $\sqrt{ }$ & $\sqrt{ }$ & $\sqrt{ }$ \\
$\mathrm{Mg}^{2+}$ & $\sqrt{ }$ & $\sqrt{ }$ & $\S$ \\
$\mathrm{Cs}^{+}$ & $\sqrt{ }$ & $\sqrt{ }$ & $\sqrt{ }$ \\
$\mathrm{Sr}^{2+}$ & $\sqrt{ }$ & $\sqrt{ }$ & $\sqrt{ }$ \\
$\mathrm{UO}_{2}{ }^{2+}$ & $\dagger$ & $\dagger$ & $\dagger$ \\
\hline
\end{tabular}

$\dagger$ sorption of actinides and REEs to aluminosilicates dominated by surface complexation in most cases and was, therefore, not included in our ion exchange model

* 3 site types on illite/mica with varying affinities.

$\S \mathrm{Mg}^{2+}$ does not exchange readily into the inner channels of clinoptilolite. 
Table E-3. Surface complexation reaction for iron oxides using the nonelectrostatic model.

\begin{tabular}{cc}
\hline Reaction & $\log \mathrm{K}$ \\
$>\mathrm{FeOH} \Leftrightarrow \mathrm{FeO}^{-}+\mathrm{H}^{+}$ & -8.93 \\
$>\mathrm{FeOH}+\mathrm{H}^{+} \Leftrightarrow \mathrm{FeOH}_{2}^{+}$ & 7.29 \\
$>\mathrm{FeOH}+\mathrm{Eu}^{3+} \Leftrightarrow>\mathrm{FeOEu}^{2+}+\mathrm{H}^{+}$ & $1.85 \pm 0.58$ \\
$>\mathrm{FeOH}+\mathrm{NpO}_{2}{ }^{+} \Leftrightarrow>\mathrm{FeOHNpO}_{2}{ }^{+}$ & $4.32 \pm 0.11$ \\
$>\mathrm{FeOH}+\mathrm{NpO}_{2}+\mathrm{H}_{2} \mathrm{O} \Leftrightarrow>\mathrm{FeOHNpO}_{3}{ }^{-}+2 \mathrm{H}^{+}$ & -11.26 \\
$>\mathrm{FeOH}^{+} \mathrm{Sr}^{2+} \Leftrightarrow>\mathrm{FeOHSr}^{2+}$ & $2.22 \pm 0.13$ \\
$>\mathrm{FeOH}+\mathrm{Sr}^{2+} \Leftrightarrow>\mathrm{FeOSr}^{+}+\mathrm{H}^{+}$ & $-5.30 \pm 0.31$ \\
$>\mathrm{FeOH}+\mathrm{Sr}^{2+}+\mathrm{H}_{2} \mathrm{O} \Leftrightarrow>\mathrm{FeOSrOH}^{+}+2 \mathrm{H}^{+}$ & $-14.14 \pm 0.40$ \\
$>\mathrm{FeOH}+\mathrm{UO}_{2}{ }^{2+}+\mathrm{H}_{2} \mathrm{O} \Leftrightarrow>\mathrm{FeOHUO}_{3}+2 \mathrm{H}^{+}$ & $-3.05 \pm 0.43$ \\
$>\mathrm{FeOH}+\mathrm{UO}_{2}{ }^{2+} \Leftrightarrow>\mathrm{FeOHUO}_{2}{ }^{2+}$ & $6.63 \pm 0.54$ \\
\hline
\end{tabular}

Table E-4. Surface complexation reactions for calcite using the non-electrostatic model.

\begin{tabular}{cc}
\hline Reaction & $\log \mathrm{K}$ \\
\hline$>\mathrm{Ca}^{2+}+\mathrm{EuCO}_{3}^{+} \Leftrightarrow>\mathrm{EuCO}_{3}^{+}+\mathrm{Ca}^{2+}$ & 4.14 \\
$>\mathrm{Ca}^{2+}+\mathrm{NpO}_{2}{ }^{+} \Leftrightarrow>\mathrm{NpO}_{2}{ }^{+}+\mathrm{Ca}^{2+}$ & 1.46 \\
$>\mathrm{Ca}^{2+}+\mathrm{SmCO}_{3}^{+} \Leftrightarrow>\mathrm{SmCO}_{3}^{+}+\mathrm{Ca}^{2+}$ & 4.62 \\
$>\mathrm{Ca}^{2+}+\mathrm{Sr}^{2+} \Leftrightarrow>\mathrm{Sr}^{2+}+\mathrm{Ca}^{2+}$ & -1.75 \\
$>\mathrm{Ca}^{2+}+\mathrm{UO}_{2}{ }^{2+} \Leftrightarrow>\mathrm{UO}_{2}^{2+}+\mathrm{Ca}^{2+}$ & 5.12 \\
\hline
\end{tabular}

Table E-5. Surface complexation reactions for aluminosilicates using the non-electrostatic model.

\begin{tabular}{cc}
\hline Reaction & $\log \mathrm{K}$ \\
$>\mathrm{AlOH}+\mathrm{H}^{+} \Leftrightarrow>\mathrm{AlOH}_{2}{ }^{+}$ & $8.33^{*}$ \\
$>\mathrm{AlOH} \Leftrightarrow>\mathrm{AlO}^{-}+\mathrm{H}^{+}$ & $-9.73^{*}$ \\
$>\mathrm{SiOH} \Leftrightarrow>\mathrm{SiO}^{-}+\mathrm{H}^{+}$ & $-7.20^{*}$ \\
$>\mathrm{AlOH}+\mathrm{Eu}^{3+} \Leftrightarrow>\mathrm{AlOEu}^{2+}+\mathrm{H}^{+}$ & $2.21 \pm 0.54$ \\
$>\mathrm{SiOH}+\mathrm{Eu}^{3+} \Leftrightarrow>\mathrm{SiOEu}^{2+}+\mathrm{H}^{+}$ & -0.62 \\
$>\mathrm{SiOH}+\mathrm{Eu}^{3+}+\mathrm{H}_{2} \mathrm{O} \Leftrightarrow>\mathrm{SiOEuO}^{+} 3 \mathrm{H}^{+}$ & -15.30 \\
$>\mathrm{AlOH}+\mathrm{NpO}_{2}{ }^{+} \Leftrightarrow>\mathrm{AlONpO}_{2}+\mathrm{H}^{+}$ & $-4.67 \pm 0.27$ \\
$>\mathrm{AlOH}+\mathrm{NpO}{ }^{+}+\mathrm{H}_{2} \mathrm{O} \Leftrightarrow>\mathrm{AlONpO}_{3} \mathrm{H}^{-}+2 \mathrm{H}^{+}$ & $-14.26 \pm 0.04$ \\
$>\mathrm{SiOH}+\mathrm{NpO}_{2}{ }^{+} \Leftrightarrow>\mathrm{SiONpO}_{2}+\mathrm{H}^{+}$ & $-3.72 \pm 0.15$ \\
$>\mathrm{SiOH}+\mathrm{NpO}_{2}{ }^{+}+\mathrm{H}_{2} \mathrm{O} \Leftrightarrow>\mathrm{SiONpO}_{3} \mathrm{H}^{-}+2 \mathrm{H}^{+}$ & -12.16 \\
$>\mathrm{AlOH}+\mathrm{UO}_{2}{ }^{2+} \Leftrightarrow>\mathrm{AlOUO}_{2}{ }^{+}+\mathrm{H}^{+}$ & $3.13 \pm 0.15$ \\
$>\mathrm{SiOH}+\mathrm{UO}_{2}{ }^{2+}+\mathrm{H}_{2} \mathrm{O} \Leftrightarrow>\mathrm{SiOUO}_{3} \mathrm{H}+2 \mathrm{H}^{+}$ & $-5.18 \pm 0.31$ \\
$>\mathrm{SiOH}+\mathrm{UO}_{2}{ }^{2+}+\mathrm{H}_{2} \mathrm{O} \Leftrightarrow>\mathrm{SiOUO}_{3}{ }^{-}+3 \mathrm{H}^{+}$ & -12.35 \\
\hline
\end{tabular}

* Surface acidity constants taken from Turner (1995) $\mathrm{SiO}_{2}$ and $\alpha-\mathrm{Al}_{2} \mathrm{O}_{3}$ diffuse layer surface complexation model data 
Table E-6. Vanselow ion exchange reactions for smectite, mica, and clinoptilolite.

\begin{tabular}{|c|c|c|}
\hline Exchange Reaction & $\log \mathrm{K}$ & Site Type \\
\hline \multicolumn{3}{|c|}{ SMECTITE $\dagger$} \\
\hline $\mathrm{Na}^{+}<-->0.5 \mathrm{Ca}^{2+}, 0.5 \mathrm{Mg}^{2+}, 0.5 \mathrm{Sr}^{2+}$ & 0.085 & \\
\hline $\mathrm{Na}^{+}<-->\mathrm{K}^{+}$ & 0.255 & \\
\hline $\mathrm{Na}^{+}<-->\mathrm{Cs}^{+}$ & 0.792 & \\
\hline $0.5 \mathrm{Ca}^{2+}<-->0.5 \mathrm{UO}_{2}^{2+}$ & -0.125 & \\
\hline $\mathrm{Na}^{+}<-->0.5 \mathrm{UO}_{2}^{2+}$ & -0.040 & \\
\hline \multicolumn{3}{|c|}{ ILLITE/MICA $\$$} \\
\hline \multirow[t]{3}{*}{$\mathrm{Na}^{+}<-->0.5 \mathrm{Ca}^{2+}, 0.5 \mathrm{Mg}^{2+}, 0.5 \mathrm{Sr}^{2+}$} & -1.026 & I \\
\hline & -0.147 & II \\
\hline & 0.000 & III \\
\hline \multirow[t]{3}{*}{$\mathrm{Na}^{+}<-->\mathrm{K}^{+}$} & 1.613 & I \\
\hline & 1.686 & II \\
\hline & 0.894 & III \\
\hline \multirow[t]{3}{*}{$\mathrm{Na}^{+}<-->\mathrm{Cs}^{+}$} & 5.718 & I \\
\hline & 3.079 & II \\
\hline & 1.539 & III \\
\hline \multicolumn{3}{|c|}{ CLINOPTILOLITE $\uparrow$} \\
\hline $\mathrm{Na}^{+}<-->\mathrm{K}^{+}$ & 1.100 & \\
\hline $\mathrm{Na}^{+}<-->\mathrm{Cs}^{+}$ & 1.708 & \\
\hline $\mathrm{Na}^{+}<-->0.5 \mathrm{Ca}^{2+}$ & -0.037 & \\
\hline $\mathrm{Na}^{+}<-->0.5 \mathrm{Sr}^{2+}$ & 0.037 & \\
\hline
\end{tabular}

$\dagger 0.85 \mathrm{meq} / \mathrm{g}$ smectite

$\$ 0.2 \mathrm{meq} / \mathrm{g}$ illite $/ \mathrm{mica}$ total, $0.005=\mathrm{I}, 0.03=\mathrm{II}, 0.965=\mathrm{III}$

ब $2.12 \mathrm{meq} / \mathrm{g}$ clinoptilolite

Table E-7. Parameters used to define reactions on mineral surfaces.

\begin{tabular}{cccccc}
\hline Mineral & $\begin{array}{c}\text { Iron Oxide } \\
\text { (hematite) }\end{array}$ & Calcite & $\begin{array}{c}\text { Smectite } \\
\text { (montmorillonite) }\end{array}$ & $\begin{array}{c}\text { Zeolite } \\
\text { (clinoptilolite) }\end{array}$ & $\begin{array}{c}\text { Illite/Mica } \\
\text { (illite) }\end{array}$ \\
\hline $\begin{array}{c}\text { Density, } \\
\mathrm{g} / \mathrm{cm}^{3}\end{array}$ & 5.27 & 2.71 & 2.83 & 2.13 & 2.83 \\
$\begin{array}{c}\text { Surface Area, } \\
\mathrm{m}^{2} / \mathrm{g}\end{array}$ & 2.0 & 2.2 & 30.0 & -- & -- \\
$\begin{array}{c}\text { Site Density, } \\
\mathrm{nm}^{-2}\end{array}$ & 2.31 & 5.0 & 0.231 & -- & -- \\
$\begin{array}{c}\text { Site Type } \\
\text { TyeOH }\end{array}$ & $>\mathrm{Ca}^{2+}$ & $\begin{array}{c}>\mathrm{SiOH}(0.5) \\
>\mathrm{AlOH}(0.5) \\
\text { (IE) }\end{array}$ & (IE) & I (0.005) \\
CEC, & -- & -- & 0.85 & 2.12 & III (0.03) $(0.965)$ \\
meq/g & & & & & 0.2 \\
\hline
\end{tabular}


Table E-8. Basis species used in CRUNCH thermodynamic database.

\begin{tabular}{lcc}
\hline & $\begin{array}{c}\text { Ion size } \\
\AA \dagger\end{array}$ & $\begin{array}{c}\text { Mol. Wt. } \\
\text { g/mol }\end{array}$ \\
\hline $\mathrm{H}_{2} \mathrm{O}$ & 3 & 18.0 \\
$\mathrm{Al}^{3+}$ & 9 & 27.0 \\
$\mathrm{Ca}^{2+}$ & 6 & 40.1 \\
$\mathrm{Cl}^{-}$ & 3 & 35.5 \\
$\mathrm{Cs}^{+}$ & 2.5 & 132.9 \\
$\mathrm{Eu}^{3+}$ & 5 & 152.0 \\
$\mathrm{Fe}^{2+}$ & 6 & 55.8 \\
$\mathrm{H}^{+}$ & 9 & 1.0 \\
$\mathrm{HCO}_{3}{ }^{-}$ & 4 & 61.0 \\
$\mathrm{~K}^{+}$ & 3 & 39.1 \\
$\mathrm{Mg}^{2+}$ & 8 & 24.3 \\
$\mathrm{Na}^{+}$ & 4 & 23.0 \\
$\mathrm{~Np}^{4+}$ & 5.5 & 237.0 \\
$\mathrm{SO}_{4}^{2-}$ & 4 & 96.1 \\
$\mathrm{SiO}_{2}$ (aq) & 3 & 60.1 \\
$\mathrm{Sm}^{3+}$ & 9 & 150.4 \\
$\mathrm{Sr}^{2+}$ & 5 & 87.6 \\
$\mathrm{UO}_{2}{ }^{2+}$ & 4.5 & 270.0 \\
$\mathrm{O}_{2}$ (aq) & 3 & 32.0 \\
\hline$\dagger$ Ion size parameter used in Debye-Huckel activity \\
coefficient model. $^{2}$ & &
\end{tabular}

Table E-9. Parameters in extended Debye-Huckel activity coefficient model as a function of temperature $\left({ }^{\circ} \mathrm{C}\right)$

\begin{tabular}{lcccccccc}
\hline Constants & $0{ }^{\circ} \mathrm{C}$ & $25{ }^{\circ} \mathrm{C}$ & $60{ }^{\circ} \mathrm{C}$ & $100{ }^{\circ} \mathrm{C}$ & $150{ }^{\circ} \mathrm{C}$ & $200{ }^{\circ} \mathrm{C}$ & $250{ }^{\circ} \mathrm{C}$ & $300{ }^{\circ} \mathrm{C}$ \\
\hline A & 0.4939 & 0.5114 & 0.5465 & 0.5995 & 0.6855 & 0.7994 & 0.9593 & 1.218 \\
B & 0.3253 & 0.3288 & 0.3346 & 0.3421 & 0.3525 & 0.3639 & 0.3766 & 0.3925 \\
$\mathrm{~B}^{\circ}$ & 0.0374 & 0.041 & 0.044 & 0.046 & 0.047 & 0.047 & 0.034 & - \\
\hline
\end{tabular}


Table E-10. Logarithm of equilibrium constants $(\mathrm{K})$ of aqueous reactions used in CRUNCH thermodynamic data base.

\begin{tabular}{|c|c|c|}
\hline Reaction & $\log \mathrm{K}$ & $\begin{array}{c}\text { Ion size } \dagger \\
\AA\end{array}$ \\
\hline $\mathrm{H}_{2} \mathrm{O}=\mathrm{OH}^{-}+\mathrm{H}^{+}$ & 14.0 & 3.5 \\
\hline $\mathrm{Al}^{3+}+2 \mathrm{H}_{2} \mathrm{O}=\mathrm{AlO}_{2}^{-}+4 \mathrm{H}^{+}$ & 22.2 & 4 \\
\hline $\mathrm{HCO}_{3}{ }^{-}=\mathrm{CO}_{3}{ }^{2-}+\mathrm{H}^{+}$ & 10.3 & 4.5 \\
\hline $\mathrm{Fe}^{2+}+0.25 \mathrm{O}_{2}(\mathrm{~g})+\mathrm{H}^{+}=\mathrm{Fe}^{3+}+0.5 \mathrm{H}_{2} \mathrm{O}$ & -7.8 & 9 \\
\hline $\mathrm{Fe}^{3+}+2 \mathrm{H}_{2} \mathrm{O}=\mathrm{FeO}_{2}^{-}+4 \mathrm{H}^{+}$ & 21.6 & 4 \\
\hline $\mathrm{Fe}^{3+}+2 \mathrm{H}_{2} \mathrm{O}=\mathrm{HFeO}_{2}^{0}+3 \mathrm{H}^{+}$ & 12.0 & 3 \\
\hline $\mathrm{SiO}_{2}\left(\mathrm{aq}^{)}+\mathrm{H}_{2} \mathrm{O}=\mathrm{HSiO}_{3}^{-}+\mathrm{H}^{+}\right.$ & 9.6 & 4 \\
\hline $\mathrm{Ca}^{2+}+\mathrm{HCO}_{3}^{-}=\mathrm{CaCO}_{3}{ }^{0}+\mathrm{H}^{+}$ & 7.0 & 3 \\
\hline $\mathrm{O}_{2}(\mathrm{aq})=\mathrm{O}_{2}(\mathrm{~g})$ & 2.9 & - \\
\hline $\mathrm{Np}^{4+}+0.25 \mathrm{O}_{2}(\mathrm{~g})+1.5 \mathrm{H}_{2} \mathrm{O}=\mathrm{NpO}_{2}^{+}+3 \mathrm{H}^{+}$ & 9.9 & 4 \\
\hline $\mathrm{NpO}_{2}^{+}+\mathrm{HCO}_{3}^{-}=\mathrm{NpO}_{2} \mathrm{CO}_{3}^{-}+\mathrm{H}^{+}$ & 5.7 & 4 \\
\hline $\mathrm{NpO}_{2}^{+}+\mathrm{H}_{2} \mathrm{O}=\mathrm{NpO}_{2} \mathrm{OH}^{0}+\mathrm{H}^{+}$ & 8.9 & 3 \\
\hline $\mathrm{Np}^{4+}+4 \mathrm{H}_{2} \mathrm{O}=\mathrm{Np}(\mathrm{OH})_{4}{ }^{0}+4 \mathrm{H}^{+}$ & 9.6 & 3 \\
\hline $\mathrm{Eu}^{3+}+2 \mathrm{HCO}_{3}^{-}=\mathrm{Eu}\left(\mathrm{CO}_{3}\right)_{2}^{-}+2 \mathrm{H}^{+}$ & 7.7 & 4 \\
\hline $\mathrm{Eu}^{3+}+2 \mathrm{H}_{2} \mathrm{O}=\mathrm{Eu}(\mathrm{OH})_{2}^{+}+2 \mathrm{H}^{+}$ & 14.9 & 4 \\
\hline $\mathrm{Eu}^{3+}+\mathrm{HCO}_{3}^{-}=\mathrm{EuCO}_{3}^{+}+\mathrm{H}^{+}$ & 2.4 & 4 \\
\hline $\mathrm{Sm}^{3+}+2 \mathrm{HCO}_{3}^{-}=\mathrm{Sm}\left(\mathrm{CO}_{3}\right)_{2}^{-}+2 \mathrm{H}^{+}$ & 7.9 & 4 \\
\hline $\mathrm{Sm}^{3+}+\mathrm{HCO}_{3}^{-}=\mathrm{SmCO}_{3}^{+}+\mathrm{H}^{+}$ & 2.5 & 4 \\
\hline $\mathrm{UO}_{2}{ }^{2+}+2 \mathrm{HCO}_{3}^{-}=\mathrm{UO}_{2}\left(\mathrm{CO}_{3}\right)_{2}{ }^{2-}+2 \mathrm{H}^{+}$ & 3.8 & 4 \\
\hline $\mathrm{UO}_{2}{ }^{2+}+3 \mathrm{HCO}_{3}^{-}=\mathrm{UO}_{2}\left(\mathrm{CO}_{3}\right)_{3}{ }^{4-}+3 \mathrm{H}^{+}$ & 9.4 & 4 \\
\hline $\mathrm{UO}_{2}^{2+}+\mathrm{H}_{2} \mathrm{O}=\mathrm{UO}_{3}{ }^{0}+2 \mathrm{H}^{+}$ & 10.3 & 3 \\
\hline $\mathrm{UO}_{2}^{2+}+2 \mathrm{H}^{+}=\mathrm{U}^{4+}+0.5 \mathrm{O}_{2}(\mathrm{~g})+\mathrm{H}_{2} \mathrm{O}$ & 32.5 & 5.5 \\
\hline $\mathrm{U}^{4+}+2 \mathrm{H}_{2} \mathrm{O}=\mathrm{UO}_{2}^{0}+4 \mathrm{H}^{+}$ & 4.6 & 3 \\
\hline
\end{tabular}

$\dagger$ Ion size parameter, used in Debye-Huckel activity coefficient model, for the aqueous complex formed by the basis species. 


\section{Appendix F. Secondary Ion Mass Spectrometry Data}

Table F-1. Analysis of selected isotope concentrations for column Experiment \#1.

\begin{tabular}{|c|c|c|c|c|c|c|c|c|c|c|c|c|}
\hline апри & $\begin{array}{l}\text { Ion Probe } \\
\text { File Name }\end{array}$ & $\begin{array}{l}{ }^{23} \mathrm{Na} \\
(\mathrm{ppm})\end{array}$ & $\begin{array}{l}{ }^{27} \mathrm{Al} \\
(\mathrm{ppm})\end{array}$ & $\begin{array}{c}{ }^{39} \mathrm{~K} \\
(\mathrm{ppm})\end{array}$ & $\begin{array}{l}{ }^{40} \mathrm{Ca} \\
(\mathrm{ppm})\end{array}$ & $\begin{array}{l}{ }^{54} \mathrm{Fe} \\
(\mathrm{ppm})\end{array}$ & $\begin{array}{l}{ }^{88} \mathrm{Sr} \\
(\mathrm{ppm})\end{array}$ & $\begin{array}{l}{ }^{133} \mathrm{Cs} \\
(\mathrm{ppm})\end{array}$ & $\begin{array}{l}{ }^{138} \mathrm{Ba} \\
\text { (ppm) }\end{array}$ & $\begin{array}{l}{ }^{149} \mathrm{Sm} \\
(\mathrm{ppm})\end{array}$ & $\begin{array}{l}{ }^{232} \mathrm{Th} \\
\text { (ppm) }\end{array}$ & $\begin{array}{l}{ }^{238} \mathrm{U} \\
(\mathrm{ppm})\end{array}$ \\
\hline $1.1 \dagger$ & R1822A.005 & 2938 & 82394 & 13583 & 63152 & 201.9 & 258.1 & 129.1 & 145.9 & 39.4 & 7.04 & 2.91 \\
\hline & & 01 & 199 & 123 & 411 & 2. & & 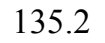 & .0 & 24.5 & 8. & 3.19 \\
\hline & & 921 & 114468 & 977 & 6299 & 380.4 & 149.6 & 23.6 & 24.3 & 24.4 & 6.25 & 7.45 \\
\hline & & 281 & 244 & 4969 & 178277 & 206.1 & 333.4 & 10.1 & 50.7 & 43.4 & 7.49 & 2.99 \\
\hline & & 71 & 19 & 832 & 2. & .4 & 8 & 3.2 & 9.5 & .90 & 5.95 & 3.00 \\
\hline & & 07 & & 041 & 191 & & 0.1 & & 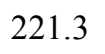 & .5 & 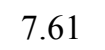 & .18 \\
\hline & & 06 & & 33 & 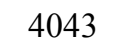 & & 1.6 & J.0 & .3 & .43 & 7.10 & 2.30 \\
\hline & & 16 & & 170 & 3517 & 0.6 & & 0.0 & 4.7 & 19.4 & 7.85 & 2.73 \\
\hline & & 47 & 00 & 451 & 19399 & 96.8 & 104.4 & 9.6 & 4.5 & 9.59 & 5.50 & 1.60 \\
\hline & & 01 & & & & & 87.5 & & & 2.00 & 4.38 & 1.72 \\
\hline & & 4236 & 364 & & 187 & 50.0 & 101.4 & 00.4 & 08.8 & 7.98 & 4.73 & 1.46 \\
\hline & & & 5993 & & & & & 0.0 & 5.6 & 936 & 3.29 & 3.80 \\
\hline & & & & & & & & & & 85 & 9.40 & 4.82 \\
\hline & & & & & & & & & .7 & 802 & & 2.93 \\
\hline & & 95 & 144 & & & 0.5 & 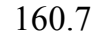 & 78.3 & 5.5 & 1.44 & 13.57 & 4.79 \\
\hline & & 29 & 442 & 068 & & 1.7 & 0 & 775.1 & .1 & 52 & 4.3 & 1.37 \\
\hline & & & & & & & & & 4.1 & 562 & 5.8 & 1.84 \\
\hline & & 4025 & 5528 & & & 3.3 & 249.5 & 31 & 8.1 & 761 & 6.1 & 1.90 \\
\hline & & & & & & & & & 0.0 & 667 & 4.90 & 1.69 \\
\hline & & & & & & & & & & 16 & 2.73 & 1.52 \\
\hline & & & & & & & & & & & & 0.09 \\
\hline & & & & & & & & & 5.3 & 37 & 2. & 0.60 \\
\hline & & & & & & & 285.1 & & 94.9 & 997 & 6.63 & 1.26 \\
\hline & & & 5058 & 1 & & & & & 5.6 & 10 & 7. & 1.69 \\
\hline & & 96 & & & 5799 & 4.6 & 250.0 & & 97.5 & 1.07 & 6.00 & 3.44 \\
\hline & & 2196 & 0041 & 280 & & & 317.4 & 0.1 & 2.2 & 721 & 7.07 & 1.85 \\
\hline & & 52 & & & 11769 & & & & & 421 & 5.17 & 2.00 \\
\hline & & & & & & & & & & & 4.98 & 1.54 \\
\hline 1.7 .2 & DR1824A.003 & 3157 & 82161 & 14388 & 5334 & 187.9 & 386.7 & 7.25 & 195.5 & 0.535 & 10.15 & 2.72 \\
\hline
\end{tabular}

$\dagger$ The sample nomenclature is the following: Flow-Through Experiment \#.Column Section \#.Spot \#. Experiment \#1 is U-1a alluvium flow-through experiment with I, Sm, Cs, Sr, and U radionuclides. Column sections are in order of flow through the column (i.e., flow goes from section 1 to section 7). Each spot number was placed randomly within the column section. 
Table F-2. Analysis of total radionuclide element concentrations for column Experiment \#1.

\begin{tabular}{|c|c|c|c|c|c|c|c|c|c|}
\hline Sample & $\begin{array}{l}\text { Ion Probe } \\
\text { File Name }\end{array}$ & $\begin{array}{c}{ }^{88} \mathrm{Sr} \\
(\mathrm{ppm})\end{array}$ & $\begin{array}{c}\text { Sr total } \\
\text { (ppm) }\end{array}$ & $\begin{array}{l}{ }^{133} \mathrm{Cs} \\
\text { (ppm) }\end{array}$ & $\begin{array}{l}\text { Cs total } \\
\text { (ppm) }\end{array}$ & $\begin{array}{l}{ }^{149} \mathrm{Sm} \\
(\mathrm{ppm})\end{array}$ & $\begin{array}{c}\text { Sm total } \\
(\mathrm{ppm})\end{array}$ & $\begin{array}{l}{ }^{238} \mathrm{U} \\
\text { (ppm) }\end{array}$ & $\begin{array}{l}\text { U total } \\
\text { (ppm) }\end{array}$ \\
\hline 1.1 .1 & DR1822A.005 & 258.1 & 2617.6 & 129.1 & 129.1 & 39.4 & 285.5 & 2.91 & 2.9 \\
\hline 1.1 .2 & DR1823A.001 & 156.9 & 1591.3 & 135.2 & 135.2 & 24.5 & 177.5 & 3.19 & 3.2 \\
\hline 1.1 .3 & DR1823A.002 & 149.6 & 1517.2 & 123.6 & 123.6 & 24.4 & 176.8 & 7.45 & 7.5 \\
\hline 1.1 .4 & DR1823A.003 & 333.4 & 3381.3 & 110.1 & 110.1 & 43.4 & 314.5 & 2.99 & 3.0 \\
\hline 1.1 .5 & DR1823A.004 & 85.5 & 867.1 & 93.2 & 93.2 & 6.90 & 50.0 & 3.00 & 3.0 \\
\hline 1.1 .6 & DR1823A.005 & 170.7 & 1731.2 & 84.9 & 84.9 & 21.5 & 155.8 & 2.18 & 2.2 \\
\hline 1.1 .7 & DR1823A.006 & 101.6 & 1030.4 & 150.6 & 150.6 & 7.43 & 53.8 & 2.30 & 2.3 \\
\hline 1.1 .8 & DR1824A.001 & 84.5 & 857.0 & 120.0 & 120.0 & 19.4 & 140.6 & 2.73 & 2.8 \\
\hline 1.1 average & & 167.5 & 1699.2 & 118.3 & 118.3 & 23.4 & 169.3 & 3.3 & 3.4 \\
\hline 1.2 .1 & DR1912A.003 & 104.4 & 1058.8 & 289.6 & 289.6 & 9.59 & 69.5 & 1.60 & 1.6 \\
\hline 1.2 .2 & DR1912A.004 & 87.5 & 887.4 & 184.9 & 184.9 & 2.00 & 14.5 & 1.72 & 1.7 \\
\hline 1.2 .3 & DR1912A.005 & 101.4 & 1028.4 & 200.4 & 200.4 & 7.98 & 57.8 & 1.46 & 1.5 \\
\hline 1.2 average & & 97.8 & 991.5 & 225.0 & 225.0 & 6.5 & 47.2 & 1.6 & 1.6 \\
\hline 1.3 .1 & DR1912A.006 & 124.4 & 1261.7 & 500.0 & 500.0 & 0.936 & 6.8 & 3.80 & 3.8 \\
\hline 1.3 .2 & DR1912A.007 & 216.1 & 2191.7 & 497.4 & 497.4 & 0.885 & 6.4 & 4.82 & 4.9 \\
\hline 1.3 .3 & DR1912A.008 & 382.6 & 3880.3 & 495.9 & 495.9 & 0.802 & 5.8 & 2.93 & 3.0 \\
\hline 1.3 .4 & DR1912A.009 & 160.7 & 1629.8 & 278.3 & 278.3 & 1.44 & 10.4 & 4.79 & 4.8 \\
\hline 1.3 average & & 221.0 & 2240.9 & 442.9 & 442.9 & 1.1 & 7.4 & 4.1 & 4.1 \\
\hline 1.4 .1 & DR1913A.001 & 203.0 & 2058.8 & 775.1 & 775.1 & 0.552 & 4.0 & 1.37 & 1.4 \\
\hline 1.4 .2 & DR1913A.002 & 215.7 & 2187.6 & 473.9 & 473.9 & 0.562 & 4.1 & 1.84 & 1.9 \\
\hline 1.4 .3 & DR1913A.003 & 249.5 & 2530.4 & 315.3 & 315.3 & 0.761 & 5.5 & 1.90 & 1.9 \\
\hline 1.4 .4 & DR1913A.004 & 217.8 & 2208.9 & 478.4 & 478.4 & 0.667 & 4.8 & 1.69 & 1.7 \\
\hline 1.4 average & & 221.5 & 2246.5 & 510.7 & 510.7 & 0.64 & 4.6 & 1.7 & 1.7 \\
\hline 1.5.1 & DR1913A.005 & 104.2 & 1056.8 & 361.5 & 361.5 & 0.316 & 2.3 & 1.52 & 1.5 \\
\hline 1.5 .2 & DR1913A.006 & 35.7 & 362.1 & 147.3 & 147.3 & 0.034 & 0.2 & 0.09 & 0.1 \\
\hline 1.5 .3 & DR1913A.007 & 75.6 & 766.7 & 248.9 & 248.9 & 0.137 & 1.0 & 0.60 & 0.6 \\
\hline 1.5 .4 & DR1913A.008 & 285.1 & 2891.5 & 368.9 & 368.9 & 0.997 & 7.2 & 1.26 & 1.3 \\
\hline 1.5 average & & 125.2 & 1269.3 & 281.7 & 281.7 & 0.37 & 2.7 & 0.87 & 0.9 \\
\hline 1.6 .1 & DR1913A.009 & 318.7 & 3232.3 & 17.8 & 17.8 & 0.410 & 3.0 & 1.69 & 1.7 \\
\hline 1.6 .2 & DR1913A.00A & 250.0 & 2535.5 & 10.6 & 10.6 & 1.07 & 7.8 & 3.44 & 3.5 \\
\hline 1.6 .3 & DR1914A.001 & 317.4 & 3219.1 & 10.1 & 10.1 & 0.721 & 5.2 & 1.85 & 1.9 \\
\hline 1.6 .4 & DR1914A.002 & 335.0 & 3397.6 & 8.10 & 8.10 & 0.421 & 3.1 & 2.00 & 2.0 \\
\hline 1.6 average & & 305.3 & 3096.1 & 11.7 & 11.7 & 0.66 & 4.8 & 2.2 & 2.3 \\
\hline 1.7.1 & DR1824A.002 & 272.0 & 2758.6 & 5.81 & 5.81 & 0.875 & 6.3 & 1.54 & 1.6 \\
\hline 1.7 .2 & DR1824A.003 & 386.7 & 3921.9 & 7.25 & 7.25 & 0.535 & 3.9 & 2.72 & 2.7 \\
\hline 1.7 average & & 329.4 & 3340.3 & 6.5 & 6.5 & 0.71 & 5.1 & 2.1 & 2.2 \\
\hline
\end{tabular}

